
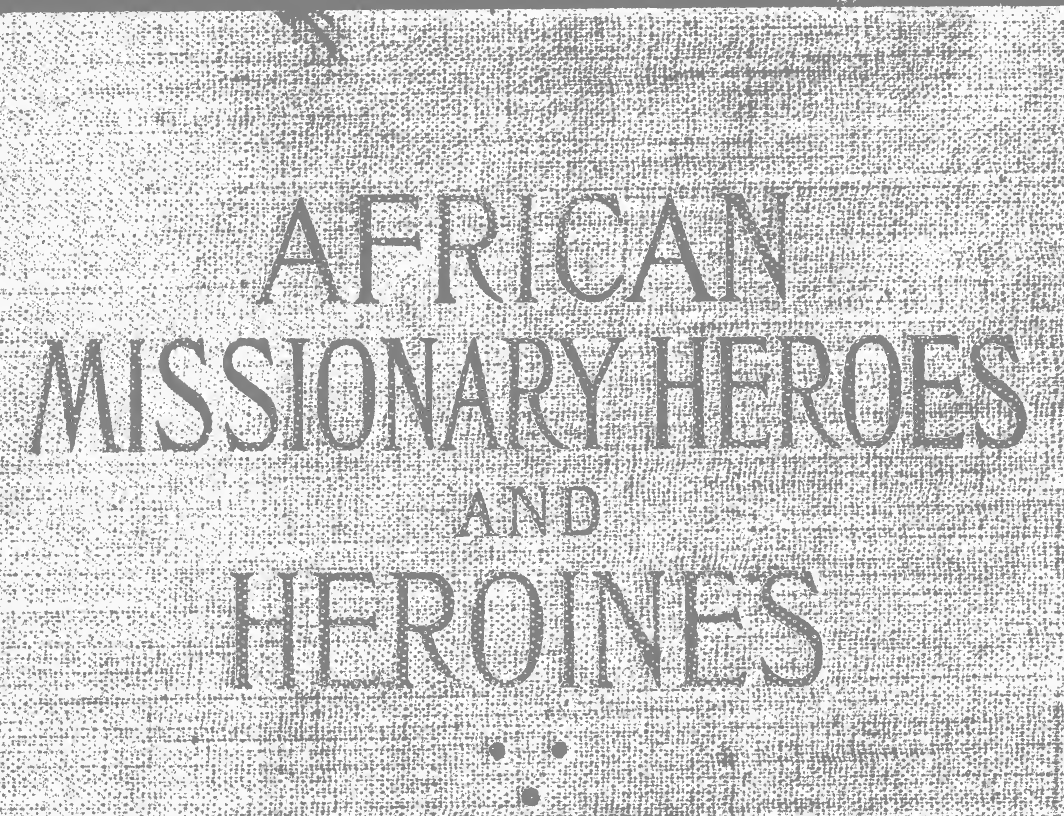
$x^{2}+2$

14

9.

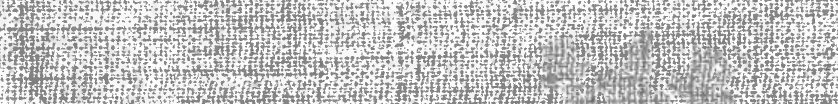
H.t.

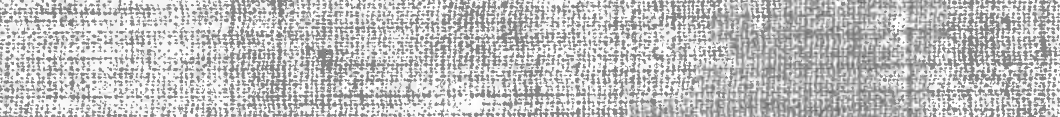

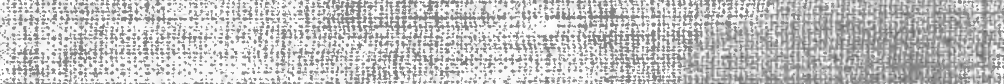

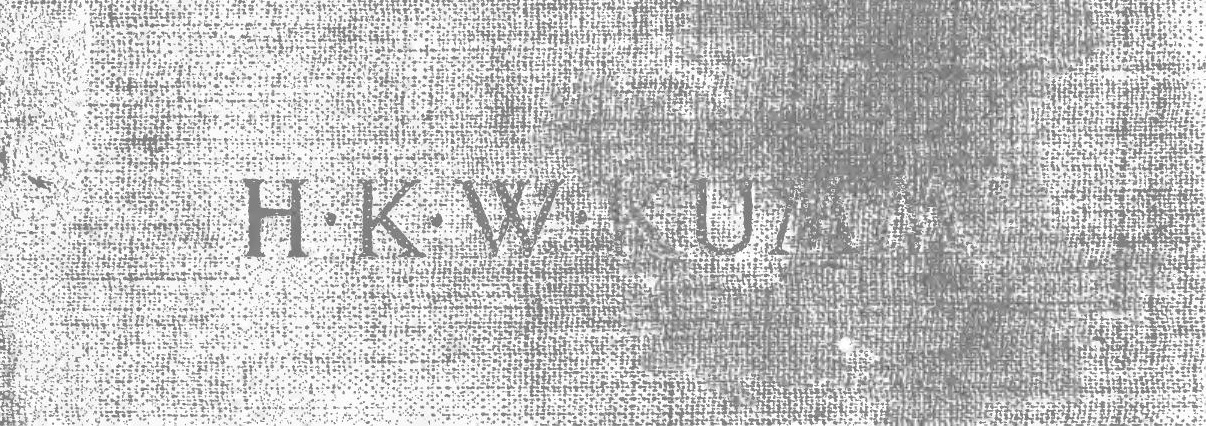

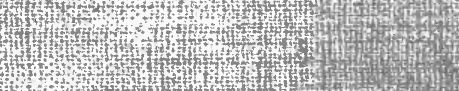




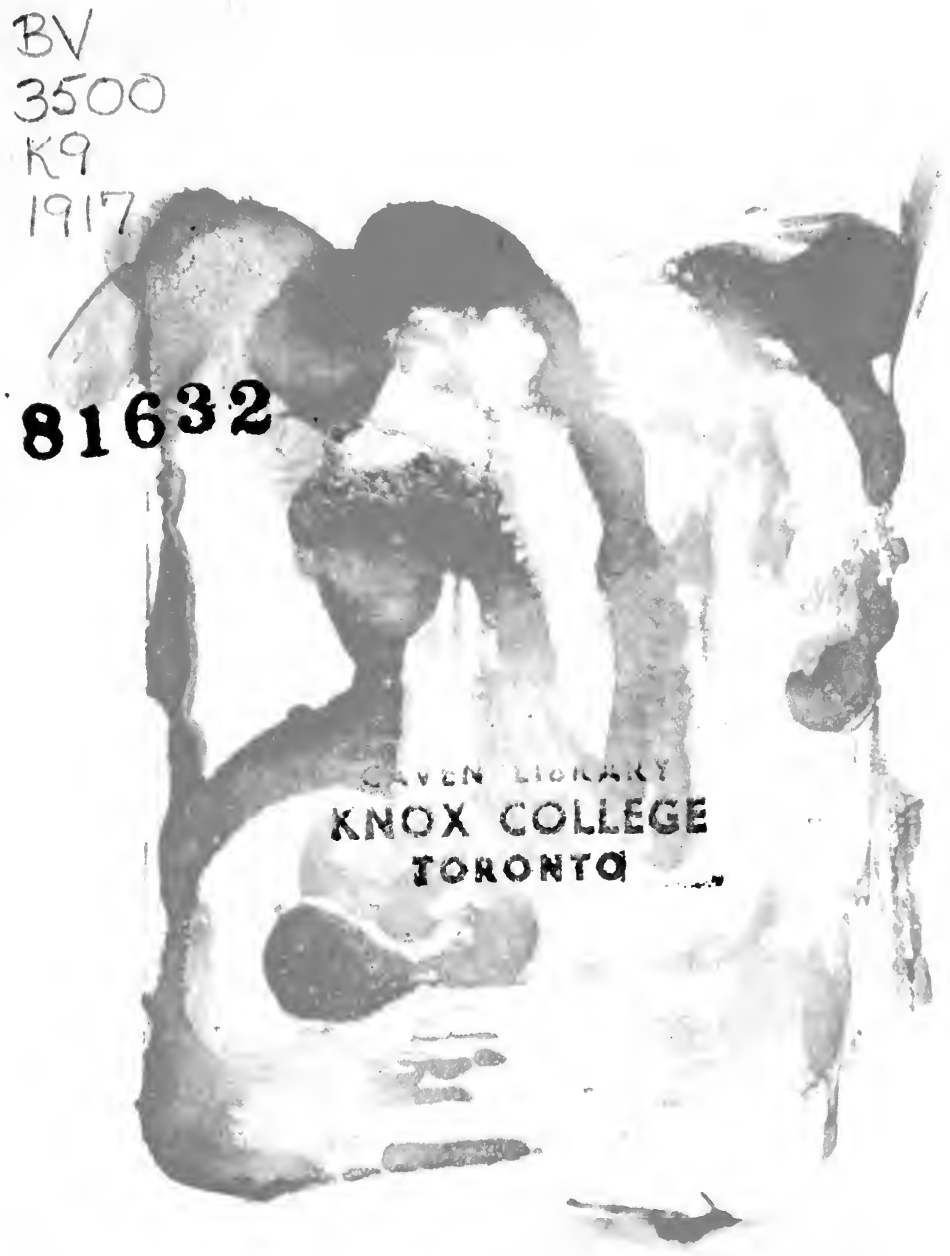


to my freid Gohu Rovellomirray H.K. Kumm. $1915=$ 



Six Lectures Given Before the College of Missions, Indianapolis, Indiana

\section{AFRICAN MISSIONARY HEROES AND HEROINES}

\section{CAVEN LIGRARY KNOX COLLEGE TORONTO}




\title{
81632
}

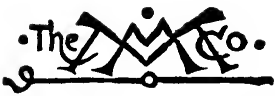 \\ THE MACMILLAN COMPANY \\ NEW YORK - BOSTON - CHICAGO \\ DALLAS - ATLANTA - SAN FRANCISCO \\ MACMILLAN \& CO., LiMITED \\ LONDON - BOMBAY - CALCUTTA \\ MELBOURNE \\ THE MACMILLAN CO. OF CANADA, LtD. \\ TORONTO
}



DUTY

to God, and to our Fellowmen was the Rule of Life of David Livingstone

It in uh the nay of duty and we shade try not to be creme helios. The know ers gowns Heavenly Father to us un voided May a de ho grace is ale. May attis blessing be on you ale. sues yours

ad enid Livingstone

From a letter written by Dr. Livingstone on September 9 th, 1857 to Miss MacGregor (daughter of General MacGregor). 


\title{
AFRICAN \\ MISSIONARY HEROES AND HEROINES
}

\author{
BY \\ H. K. W. KUMM
}

AUTHOR OF "FROM HAUSALAND TO EGYPT," "THE LANDS OF ETHIOPIA,"

"TRIBES OF THE NILE VALLEY," "THE NATIONAL ECONOMY OF NUBIA," "THE SUDAN"

3ew Oork

THE MACMILLAN COMPANY

I9I 7

All rights reserved 
Copyright, I9I7,

By THE MACMILLAN COMPANY

Set up and electrotyped

Published, November, I9I7 


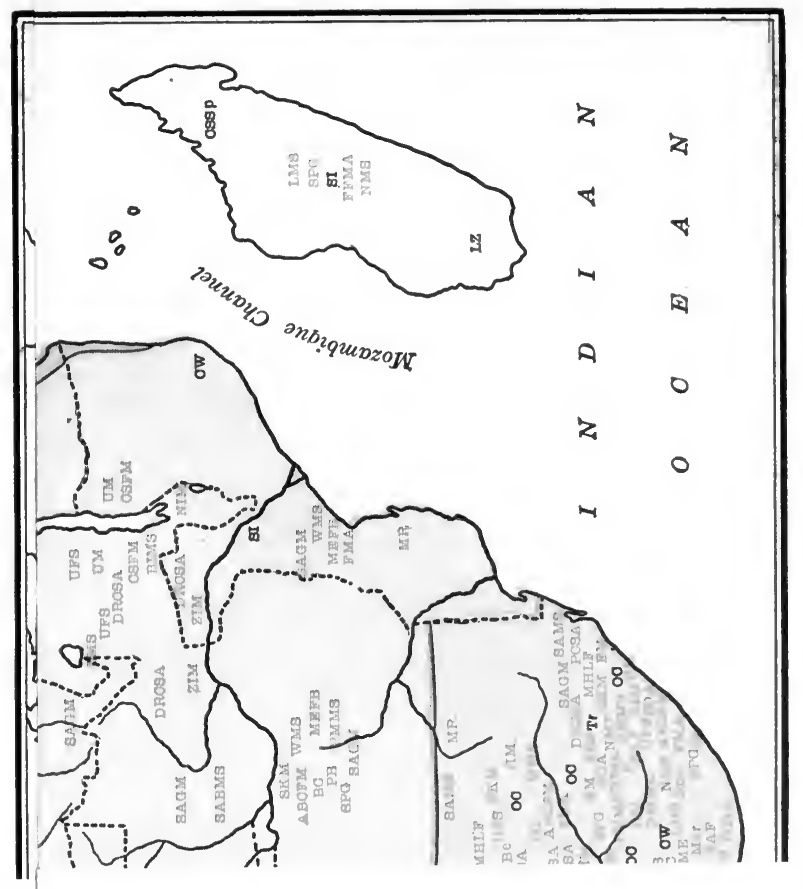




\section{PREFACE}

Were it but possible in the time and space that can be given to this book to write of Stanley and Lavigerie the cardinal, of Gordon and Rhodesia Rhodes, of Bishop Hall and Hannington, of Thornton, Pilkington, and Andrew Murray, of Mary Kingsley, Mungo Park, and Samuel Baker, of Rebman, Schoen and Klein, of Barth and Nachtigal, of Denham, Junker, Overweg and Vogel, of Browne, and Speke, and Grant, and van der Decken, of Gordon Cumming, Arnot, Emin Pasha, of Madame Tinney, Schweinfurth and Selous, of Bishop Gobat and his Pilgrim Street to Abyssinia, of church-fathers, Cyril, Cyprian, and Athanasius, of Clement, Origen and Tertullian, and of the greatest of them-St. Augustine-and many more; for days, and months, and years, were one to write, and tell the tales-innumerable, thrilling - of all these mighty men, whose names you see here on this page, we should have failed to mention most of Afric's heroes. 


$$
\text { . }
$$




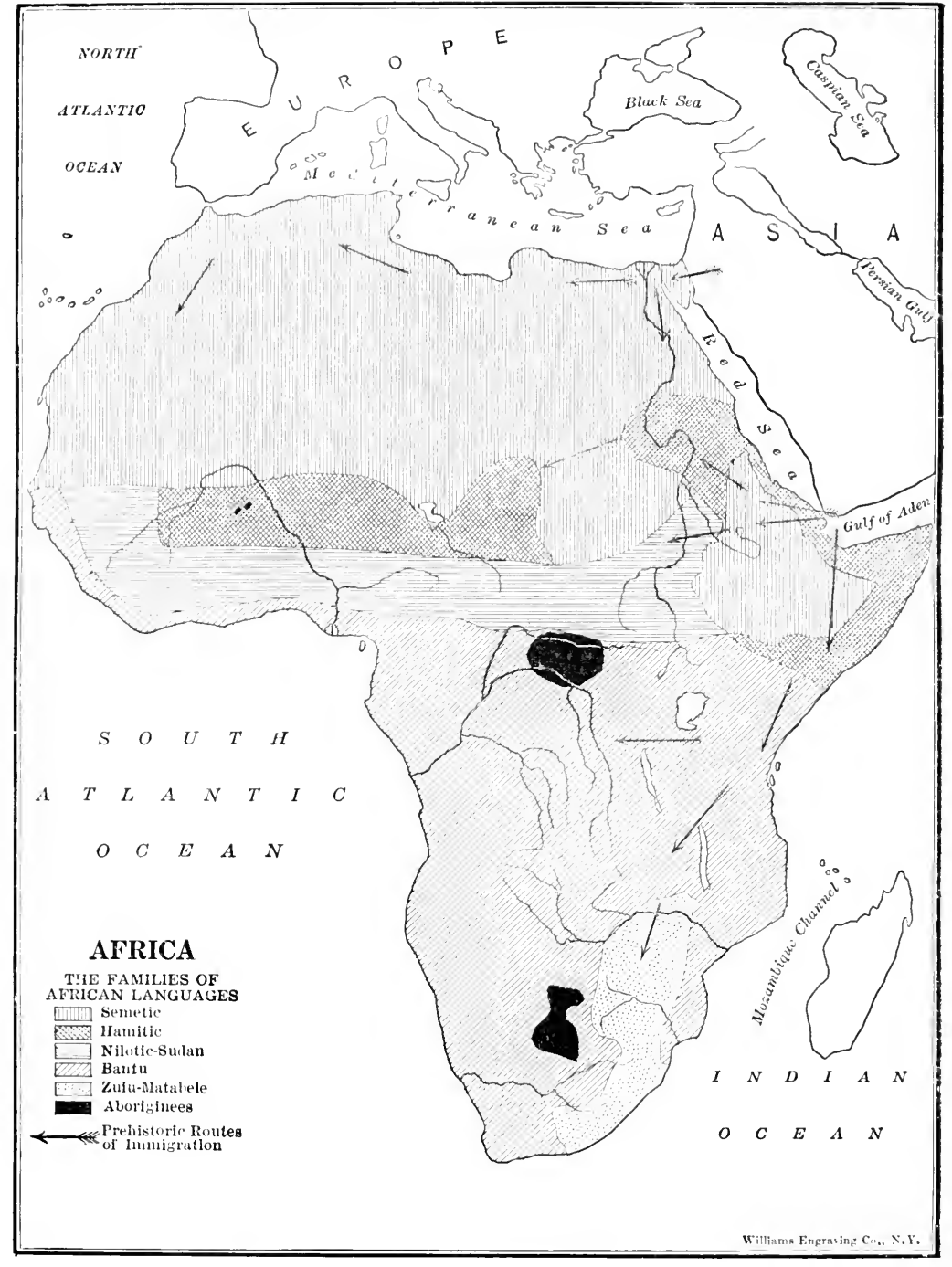




$$
\text { • }
$$




\section{CONTENTS}

\section{PEOPLE OF VISION}

CHAPTER

I. From the Ruins of the Amphitheater in CarthageA Picture of Perpetua.

The last of the Christian Rulers of North AfricaCahina, the Royal Martyr.

II. On the Ubangi and the Niger, Graham Wilmot Brooke, a soldier of the king, and then a Soldier of the King of kings.

A Slave who became a Bishop-Crowther, the African Saint.

III. François Coillard of the Barotse.

A Pioneer among the Bantus-Grenfell of the Congo.

IV. The Sower of East Africa, and Krapf's Memories of Abyssinia.

A Woman and a Missionary-Mary Slessor.

V. A Missionary and an engineer-Mackay of Uganda. The lion-headed Bishop-Tucker.

VI. The Smoke of a Thousand Villages, as seen by Robert Moffatt of South Africa.

The Pathfinder-David Livingstone.

$V$ ision is Imagination guided by Wisdom, And Wisdom is the Dominion of Knowledge.

$$
\begin{gathered}
\text { Wis }=\text { Wissen }=\text { Knowledge } \\
\text { Dom }=\text { Dominion } \\
\text { ix }
\end{gathered}
$$





\section{INTRODUCTION}

The world is dominated to-day by the Aryan or Caucasian race. Of five continents, three-Europe, America and Australia - are wholly in its hands, and the overwhelming majority of the countries of the other two are also under its control. The Aryan race, with the exception of the Turk, is nominally Christian, and of the seven countries of Asia and Africa still more or less independent, in Asia two are predominantly pagan-Japan and China; three MohammedanBaluchistan, Persia, and Arabia; and in Africa twoAbyssinia and Liberia, semi-Christian, and pagan, with increasing Moslem influence.

In the international economy of the world the attention paid by the dominant race to the countries of Asia far exceeds that paid to Africa. In the chancellories of the European and American states and empires, Africa and Japan are about on a level. Among business men of the world it is much the same, and the Christian missionaries of Africa have complained, not without reason, to their several boards that Africa -the "Cinderella"-is unwarrantably neglected. Even the North and South Poles have had more attention paid to them in the newspapers than has the richest of the five continents-the continent of the future. 
Let us for a few minutes look at this continent from the standpoint of the geographer. Let us consider:
a. Its size,
c. Its climate,
b. Its wealth,
d. Its people.

(a) Its size. Africa is four and a half times as large as the United States. It is as large as the United States plus the whole of Europe, plus the whole of India, plus the whole of China; and there is room for a dozen Japans to be tucked away in the corners. Africa is five thousand miles across, and five thousand miles long.

(b) Its wealth. Africa is far and away the richest of the five continents. More than a third of the whole gold output of the world ( 40 per cent.) comes from one town in Africa alone-Johannesburg; and there is gold in southwest Africa, and southeast Africa. There is gold on the Congo and on the Shari. There is gold in the Libyan Desert and on the Gold Coast.

The diamond trade of the world (that is the trade in the most precious of stones) is controlled by the de Beers mines of Kimberley in South Africa.

Any one who knows the copper trade, knows the Katanga district of the Upper Congo. Probably the largest tin deposits are on the Bukuru Plateau in Northern Nigeria. There are silver and nickel, and many other minerals in Africa.

The backbone of Africa is the Central African Ironstone plateau, a country about the size of the United States, with vast coal deposits embedded in it, but utterly unexploited up to the present. The finest cotton 
is grown in Egypt. Kola-nuts, ground-nuts, palm-oil, ostrich feathers, morocco skins and ivory-in fact all the most valuable natural products Africa has in abundance waiting for the future. Africa must therefore be called "The Continent of the Future."

(c) Its climate. Africa is a continent of contradictions. It is the richest of the five continents, and yet there are people in it so poor that they are absolutely innocent of clothing. In the matter of health too, Africa has extremes. In North Africa and South Africa (countries each the size of the United States) we have one of the best climates- "the Health Resorts of the Future"; while the West Coast is called the "White man's Grave," and the East Coast is almost as bad. The plateau region in the interior is fairly healthy, but in the forest belt of the Congo, the Zambesi, and the Lower Niger, malarial fever is rampant. The most equitable climate (that is to say the climate with the least changes of temperature between day and night, winter and summer) is possessed by the West Coast of Africa, and that is the reason why it is deadly. The greatest variations of temperature between day and night are found in the Sahara, and that makes the oases of the Sahara replicas of an earthly paradise.

Deadly epidemics, such as sleeping-sickness, cerebrospinal meningitis, small-pox and others, have swept through certain regions of Africa, and at times decimated the population. A great deal of research work is now going on in regard to these epidemics; and when once they are conquered, large parts of Africa will lose 
their terror for the traveler, the Government agent, the scientist, the business man and the missionary.

(d) The People. The population of Africa, now about a hundred and fifty millions, will doubtless increase rapidly in the near future. Moslem slave raids, intertribal wars, religious human sacrifices,-the work of the witch-doctor, - and epidemics, have been, and are being, dealt with by the governments now controlling the various parts of the continent. There is no reason why the population of Africa should not double in a generation or two, and then double again, and so on. No other people-given peace and freedom from epidemics-increase as rapidly as the Africans, and there is room in Africa for a thousand million people.

What types of human beings are found to-day in the Dark Continent? There are six families of nations in Africa.

In the North:

(I) The Semitic people including

The Copts in Egypt,

The Berbers (Kabyls) in Tripoli, Tunis, Algeria and Morocco,

Touarek (Imoshag-freeborn) of the Sahara oases,

The Arabs and

The Abyssinians.

(2) The Hamitic people living south of them, partly in the desert and partly on the northern slopes of the Sudan. They include:

The Nubians,

The Bishareen, 
The Hadendowa,

The Fulanis, and others.

To the South of them we find

(3) The Nilotic tribes and the Sudan peoples speaking at least fifty different languages and dialects. Among the Sudan tribes are the tallest people in the world, the Shilluks and the Dinkas (six feet six inches on the average). South of the Sudan tribes in the forest belt and the coast region live

(4) The Bantus, next to the aborigines of Africa, the weakest, mentally and morally, whose villages were the happy hunting-grounds of the slave-raiders. The colored people of the United States are the descendants of the Bantus.

(5) The Zulus and Matabeles of South Africa, with their clik languages, and

(6) The Hottentots, Bushmen and Pigmies, who are probably the aborigines of the Dark Continent.

As to religions, the Semitic and Hamitic people are Mohammedan; Zulus and Bantus are pagan or heathen; and the Sudan and Nilotic tribes are half pagan and half heathen. The latter form the backbone nations of Central Africa, and are now in danger of going over to Mohammedanism for the lack of Christian missionaries; for between the Niger and the Nile (a distance of I,500 miles) there is to-day no Christion missionary work being done, and this is the strategic position of the missionary world at this moment.

Archdeacon Sell of Madras, one of the leading authorities on Mohammedanism, has written from India, 
seeing the great needs of that Eastern empire before his eyes-

"There are times when it is very difficult to balance the competing claims of various parts of the mission-field. I see no difficulty now.

Certain parts of Africa form now, in military language, the objective, and are the strategical positions of the great mission-field. Parts of Africa in which the Moslem advance is imminent have, for the present, a pre-eminent claim."

Subjoined are the names of tribes in the Sudan that have no Christian missionary among them.

In Bornu: the Borlawa and Gamawa, I00,000; the Bedde, I00,000; the Babbur, I00,000; the MarghiMarghi, 250,000; the Keri-Keri and Ngizim, 50,000; the Burra Nyong, 50,000; the Gamerghu, I00,000; the Budduma, 50,000-total 800,000.

In Adamawa: the Reibuba, 250,000; the Lam Pagans (seventeen districts) 50,000; the Tangele, 50,000; the Musgun (thirty-two districts) 50,000; total, 400,000 .

In Bagirmi: the Nilim, 50,000; the Kirdi, the Korbol, the Sango, the Lame, the Lai, and the Sara.

In Wadai and Darfur: the Kreish and the Banda, each of these inhabiting a country about the size of France. Their number is not known.

In Kordofan: the Nuba, 50,000 to 100,000.

Besides these, in the Anglo-Egyptian Sudan are the Beir, the Bongo, the Shuli, the Bari, the Makraka, the 
Bolanda, the Ngolgolawa, the Golo, the Shatt, the Mandala, the Jur, and the Berta; and in Northern Nigeria are the Gurkawa, the Montoil, the Afo, the Maguzawa, and others.

Is the religion that preaches slavery, that degrades women, that has ruined every country where it has gone, that has devastated North Africa, slaughtered the tribes of the Upper Nile under the Mahdi, and shows itself to-day in the Armenian massacres-is that religion to dominate the continent of the child-race, the richest of the five continents-the "Continent of the Future"? This question will have to be answered by this generation.

"There is offered to the young men and women of the twentieth century no greater opportunity for noble service and superb heroism than the contest which is now on for pagan Africa," says Wilson S. Naylor in his "Daybreak in the Dark Continent."

The Cross, surmounting the Crescent, must form our Anchor of Hope for Africa. 


\section{CHAPTER I}

From the Ruins of the Amphitheater in Carthage A Picture of Perpetua 


\section{PERPETUA-MARTYR}

I80 A. D. She was born. Her father was a pagan, her mother probably a Christian, both of good family.

201 A. D. She was married.

202 A. D. She and her husband were baptised when imprisoned under procurator Hilarianus. (The proconsul had recently died.) This persecution took place when Septimius Severus (I93-2 II) was emperor. His edict of 202 A. D. forbade conversion to Judaism and Christianity.

202 or 203 A. D. She was executed with several of her friends in the amphitheater at Carthage. She was thrown in a net before the horns of a wild bull, and when the bull did not kill her outright, a bungling young gladiator hacked her slowly to pieces, on March the 7th (Roman Calendar) or March the Ist (Greek Calendar).

Her body was buried in the great church in Carthage and is said to be now preserved in the Church of the Franciscans at Bologna.

Vide: Tertullian (De Anima c. 55)

Augustine (Sermons 280, 283, and 294) 


\section{CHAPTER I}

The ruins of Carthage, the rival of Rome, lie around us, - mounds of rubbish where marble monuments once adorned the mighty mistress of Africa, the home of Hannibal and Hasdrubal. One solitary building yonder in the distance has been reared on the dust and ashes of the city-a cathedral in the cemetery of an ancient civilization, - a house of God planned and built by that great man who did so much to liberate Africa's slaves, the father of the Pères Blancs, Cardinal Lavigerie.

We sit on the remains of the higher tiers of the amphitheater. Beneath us lies a little stretch of level ground, and on it stands a cross to commemorate the death of the blood-witnesses of the Christ-martyrs who were slaughtered here when Rome ruled in Numidia, Lybia, Mauritania and Barka, and with steel fists, ungloved by velvet, dominated the world.

Memory wanders back through the centuries, and before our eyes arise scenes of early days-we dream of Dido, the wily leader who with an ox-hide cut to strips redeemed the promise given by the savage ruler of the land that all the ground a beast's hide might enclose should be hers. Thin she cut the strips, and she surrounded land enough to build a goodly fort upon. 


\section{AFRICAN HEROES AND HEROINES}

We dream of Eneas, the homeless wanderer, who, after Troy had fallen, found his way, after long journeyings, to Carthage. Of Scipio Africanus we think and the younger Scipio, who ploughed the ruins of this city and with salt he sowed it, and thus cursed the land, then-of Perpetua.

Years pass, and out of the salt-sown débris, out of the horrible debacle, new life arises like a phœnix out of ashes. Once more temples crown the hill-tops and well-paved Roman streets wind in and out among the palaces. . The rivers of blood and tears that had moist. ened the ground into which new seed has fallen, have produced another crop of pomp and pleasure. Swarthy dwellers of the southlands, rich Jews and Gentiles, barbarian Goths and Gauls, Roman legionaries and Roman ladies, mingle in open squares, the market-place, the judgment hall, the circus. Poor natives of Numidia, hard-working fishermen and farmers, have founded homes in mud-walled huts and hovels in the suburbs.

Adown one of the arteries of trade and traffic comes a cavalcade. The insignia of the pro-consul are carried aloft by the first horseman. The troop halts. The hand of one of the equestrians unrolls a scroll, and with far-sounding voice he reads a proclamation:-

"Ye men of Carthage, be it known to you that the divine Imperator has commanded that all men everywhere be loyal citizens. There has arisen in the Empire a superstition endangering the peace, prosperity, and happiness of our subjects. Be it 
known to you that throughout our lands ignorant fellows have made a god of a malefactor, condemned by Roman law. They are despisers of our laws. They will not sacrifice to throne and crown. For years, in patience, we have waited that these childish people might return to the obedience due the state, but they refuse, and so we now decree that they be brought to judgment.

"You are commanded that wherever you may find them to take and hold them, and to bring them to the consul. Let it be done. Farewell."

Thus was initiated the martyr age of the infant church of Christ. Men and women, yea and little children, were torn from their homes, were judged to be dangerous citizens and condemned to die. The prisons were full of them. Daily executions took place. Some of the Christians were reserved for show purposes, for in those days killing of the human was judged a spectacle worth seeing.

Two pictures-one painted in colors and the other in words-one staged in Ephesus and the other at Rome,- "Diana or Christ" and the culminating incident in "Quo Vadis," were probably based by the artists on the historical records of the life of Perpetua of Carthage. In the painted picture, ${ }^{1}$ Edwin Long substitutes the statue of Diana for the Roman emperor: and in his great book, "Quo Vadis," Sienkiewicz saves the Christian girl from the horns of the wild bull by the hands of a giant Polish servant.

1 "Diana or Christ" by Edwin Long, Royal Academy, London, 188r. 


\section{AFRICAN HEROES AND HEROINES}

As we sit here on the ruins of the amphitheater, the tragedy of Perpetua-nay, not tragedy but glorious martyrdom,-as recorded in church history, takes shape before our eyes.

The Prætorian guards have taken her from her home and have brought her before the judgment seat of the pro-consul. The bloom of childhood has hardly left her; shy and innocent she stands before the kindly Roman governor.

"Young woman, thou art reported to be a Christian. Take this incense from the hands of the priest and place it on the altar there before the statue of the Emperor." With wondering eyes she looks at the judge,-she whose life or death is held in his hand.

"I cannot do that. I am a Christian."

"Do not keep us waiting, foolish child. Do as you are told."

Behind her stands her father, who sees his own darling little one in more cruel danger than either he or she had ever faced before.

"Child, obey!"

"I cannot do it, Father: I am a Christian."

By her side see one who loves her better than his life,-his hands outstretched to her.

"Oh dearest, you will kill yourself, and you will kill me too."

"My husband, my master, I will do anything you tell me to, except this. I cannot do it; I am a Christian."

The fatherly eyes of him who sits in the hard seat of the weigher of right and wrong are moist. 
"Come, child. Think as you like, but do as you are told. I am here to carry out the laws of Rome. I, too, must obey. Here is the incense. Sacrifice!"

The downcast eyes of Perpetua are raised; her trembling figure straightens itself; her face begins to shine, and from her youthful lips there comes the steady answer.

"I cannot and I will not do it, for 'Christ is my life, and death is my gain." " (Phil. i. 2 r.) The words of St. Paul, the apostle, have oft been echoed by the Christians in the days of persecution. The song of the martyrs is again heard from the lips of one about to die for the faith-"Christ is my life: death is my gain."

The pro-consul cannot speak, but, schooled and nurtured in Rome's ways, where life is cheap, the individual nothing and the state all, gives a signal to the executioners, who hurry her away, and in this amphitheater throw her in a net to a wild bull. And thus she dies and on this yellow sand her blood flows.

Her name was Perpetua. She was steadfast and faithful unto death, and received the Crown of Life. She died. She gave her life as others had given theirs before, and yet others gave theirs later,-an army that fought a fight for right and righteousness, and won the battle through self-sacrifice, that gave no suffering to others, but suffered shame and slander manifold. Thus was manifested in the history of that day one of the superhuman laws of God, that seed must first be laid into the ground before it can produce a 


\section{AFRICAN HEROES AND HEROINES}

harvest. "The blood of the martyrs is the seed of the Church." Blood drenched the ground and from it grew the Church.

The Roman conquest of Egypt (B.C. 32) prepared North East Africa and South West Asia (which had been under the rule of the Ptolemies since B.C. 304), through Alexandria, just as Antioch, the capital of the Seleucid successors of Alexander, prepared Asia. As the meeting-place of Greek philosophy, Jewish thought, Roman provincial polity, and Oriental commerce, Alexandria became the intellectual center of the world. The first Ptolemy had formed a royal school of learning in two departments-the Museum, or University, in his own palace, and the Library (with its 700,000 rolls and volumes) which had overflowed into the Serapeum. These two corner-stones of Greek and Roman paganism were so won to Christ that North Africa became the most advanced portion of Christendom. In their own quarter of the city the Jewish scholars, under royal patronage, had produced the Greek version of the Old Testament known as the Septuagint, which has been called by a recent popular writer, "The First Apostle of the Gentiles." Just before John Mark preached Christ in the halls of Alexandria, following the Jews of the Dispersion who had been converted at Pentecost and had returned to Cyrene with the good news of God, Philo the Jew, the contemporary of Jesus Christ, had formulated a theosophy from the later theology of the Rabbis and the teaching of Plato, which for many became a stepping-stone through the 
Gospel of John, to the unclouded revelation of God in Christ. ${ }^{1}$

In history, as well as in the individual life, cause and effect can oftentimes be clearly traced. That in the jeering multitude that gloated over the sorrows of the Savior, Simon of Cyrene, the only African of whose presence we read, should do the kindest act to the Son of Man on that day, must of necessity secure for Africa a reward.

The minister of Queen Candace is singled out by the Holy Spirit as the first foreigner to whom an Apostle was sent after the resurrection of Christ. There is little doubt that Egypt was visited by one or more of the Apostles.

The civilization already established in the northern littoral of Africa formed a suitable soil for the receiving of the religion of Jesus, the Son of God. The population of Northern Africa, to-day only about twenty millions, probably amounted to from sixty to eighty millions in the time of Christ. Egypt, Tunis, Algeria and Morocco (together nearly the size of the United States) have one of the most wonderful climates in the world.

The first Christian college, the Catechetical School of Alexandria, was founded about A.D. I80. The first three heads of this college were Pantænus, Clement and Origen. ${ }^{2}$ The desert-places and Nile Islands taught the men, surrendered to the teaching of the Savior, the desirability of loneliness. The monks

\footnotetext{
${ }^{1}$ George Smith. "Short History of Christian Missions." Page 54.

'Schaff-Herzog, "Encyclopedia of Religious Knowledge."
} 


\section{Io AFRICAN HEROES AND HEROINES}

of the Thebais exercised a powerful influence on the Christian world of the early centuries. Bishoprics grew up everywhere, from the Gulf of Akaba to the Atlas Mountains; there were eight hundred of them in the time of Constantine. Half the Fathers of the church were North Africans. There is no Christian ecclesiastical history in which the Church of North Africa, during the second, third, and fourth centuries after Christ, does not take a prominent part.

The names of men like Clement, Origen, Athanasius, Cyril of Alexandria, Tertullian, Cyprian of Carthage, and Augustine of Hippo are among the greatest in our Church history, and all were North Africans. The Nubians became early converts to our Christian faith. Through the Gazira (the land lying between the Blue and White Nile) and Arabia, the gospel spread to Abyssinia. In the oases of the Libyan Desert, the ancient Egyptian and later Roman temples were turned into Christian churches. The Troglodytes of the Mountains of Ghurian in Tripoli carried the Cross to the Tuareck-(the Imoshag, the free-born of the desert) - in the oases of the Sahara.

To this day the Cross is a far more common sign among the Tuarecks than the Crescent. It is marked on the sheath of every sword, on the dagger and the spear, on the shield, and on the saddle of the horse and the camel.

The news of the crucified Savior of the world spread far into the interior of the continent. Only the other day a letter from one of the missionaries in Central Africa told of a tribe that (when asked 
what God they worshiped) said their God was a man who had never done wrong, who healed all the sick, and died for the sins of the people.

The richest legacy ever given to the world by the Lord of Life for the unborn children of the future is entrusted to the Church-the message of the mystery of the Christ. The tribes and nations of Africa lay before the Christian Church of the north-a vast wild land, waiting for the plough and the seed of the sower. Humanly speaking, a century or two should have sufficed for the church, in obedience to the command of the God-Man, "Go ye into all the world, and preach the Gospel to every creature," to reach all the countries of the dark continent.

Thus far the people that had given the Christ His cross-bearer had been blessed beyond any other nation; they were placed in trust of the child-races of the world, but-they failed.

The Emperor Hadrian, in A.D. 134, in a letter to his brother-in-law preserved by Vopiscus, writes of Alexandria,

"The city is rich and populous: no one lives there in idleness. They have one God: Him the Christians, Him the Jews, Him all the Gentile people worship; and I would that this city were of purer morality, since it merits by its magnitude the supremacy of Egypt."

Pride, that led the Spirit of Light-Lucifer the Angel of the Dawning-to his downfall, led the great first-born Church of North Africa to its destruction. 


\section{2 AFRICAN HEROES AND HEROINES}

The sacrifices of the martyrs of Carthage and the searching Confessions of St. Augustine of Hippo were worthy of a better fruit than we find growing under Cyril of Alexandria, under Synesius of Cyrene, and among the Kabyl churches of the west.

The early days of the Fourth Century saw the Athanasian struggle against the Aryan apostacy. In the Athanasian Creed we have the statement of an African, which confirms in cold, hard language the essentials of the Christian faith.

Ecclesiastical struggles led in time to open war. The ferocity with which this war was waged and the savagery which was displayed by the Aryan Vandals on their invasion of Northern Africa have become proverbial. The history of their ruthless atrocities, the murder of the innocent, rapine and rape, and the delight in them on the part of the wild northern hordesfar more worthy of the name of Servants of Satan than Followers of the Christ-remain for ever a memento of shame for the Christianity of the Fifth Century.

If the Church of North Africa had given itself whole-heartedly to the call of the great continent lying southward, and had obeyed the Marching Orders of the Master, if it had carried the Gospel to the Niger and the Shari, the Congo, and the Zambesi, and had gathered the nations sitting at its gates, who were strangers to the Christian commonwealth of hope, into a fellowship of communion with Jesus, instead of spending unnecessary time on ecclesiastical struggles, what a different history would have to be written both of 
the Middle Ages and of modern times! In the good providence of God, enlightened North Africa had been given a task-the task of making and modelling the future of the dark-skinned children of the sunny south. What a great task-and what an abject failure - lies here before us! The North African church is guilty, first, of wasting its energy in fruitless theological discussions; secondly, of that which grew out of them-war; and thirdly, of disobedience to the last commands of Jesus Christ to spread the Gospel.

Dismal must now become the prospects of that Church! In vain are all its schools, libraries, cathedrals and palaces-outer shells, the kernels wormeaten, trees without sap, luster without life! Faith has become hypocrisy, and truth a lie!

The Great God Who is Truth has made it one of the fundamental laws of the world, that all untruth must perish, and hypocrisy (the shameless sham) can last but a short time. Christ never said of the Sadducees what $\mathrm{He}$ said of the Pharisees. Ignorance is distressing, but pompous deceit is an outgrowth of Hell.

"Mene, Mene, Tekel, Upharsin" did not only appear on the walls of Babylon, but it is written all through history, whenever nations or branches of the Church, or individuals, fall short of truth-that is, of morality in the wider sense. 



\section{CHAPTER I (Continued)}

The last of the Christian Rulers of North Africa, CaHina, the Royal Martyr 


\section{CAHINA-QUEEN AND MARTYR}

Queen Cahina, or as she was known to her people, Dhabba, was probably the daughter of the Roman prefect, Gregorius of the Cyrenaica. The date of her birth is unknown. Her capital was Constantine (Algeria).

699 A. D. She was defeated by Hassan Ibn Annoman.

700 A. D. Executed as a martyr in Egypt, because she refused to renounce her Christian faith.

Vide:-Washington Irving-"Mahomet and his Successors" and Condé "The Arabs in Spain." 


\section{CHAPTER I (Continued)}

AMRU, the general under the second Khalifa Omar, was in Syria when a messenger reached him from Mecca, sent by the Kaliph at the suggestion of Othman, the counselor. The messenger carried the following letter-

"If this epistle reach thee before thou hast passed the boundary of Egypt, go instantly back; but if it find thee within the Egyptian border, march on with the blessing of Allah, and be assured I will send thee all necessary aid."

The general expected some such message, but, being anxious to carry the flag of the Crescent into Africa, though he had but five thousand men with him, he crossed the border before he permitted the runner from Mecca to deliver his communication. In the presence of his officers he opened the letter and read it to them, then asked whether they were still in Syria, and when informed that the border already lay behind them said, "We will proceed with the blessing of Allah and carry out the commands of the Kaliph." Full of enthusiasm, and buoyed up by victory, they reached the walls of Misrah, the ancient Memphis, the capital of Egypt. Some of the smaller towns near the border had quickly fallen before his vigorous onset, and Misrah too submitted after a siege of only seven months. Reënforce- 


\section{8 AFRICAN HEROES AND HEROINES}

ments had been sent to him from Arabia, but even with these added to his small army, it would have been utterly impossible for him to subjugate the strongly fortified ancient capital of the Pharaohs, had it not been for the treachery of the Egyptian commander (a Jacobite Copt named Mokawkas). Now the Jacobites of Egypt at that time were bitterly opposed to the Greeks who, under the rule of the Emperor of Byzantium, held sway over Egypt. So bitter was the feeling between these two branches of the Christian Church, that the Copts preferred to submit to the Moslem Arabs rather than to continue subjects of Christians who belonged to another branch of the church. The second factor, perhaps as weighty if not more so, was, that Mokawkas held in trust for the Emperor, tribute and taxes collected in Egypt, and a vast amount of wealth that had accumulated in the capital. In his agreement to surrender the city, he stipulated that the government treasure should be his. This was conceded by Amru, who was anxious to have Egypt at his feet, knowing full well that none of the riches of the land could permanently escape him or his people. We have exemplified, in the action of Mokawkas, the low type of morality then prevalent throughout North Africa.

The second city of Egypt-Alexandria-put up a better fight. Here a Greek was in command. By repeated sallies he frequently drove the Arabs far from the gates. For fourteen months the battle continued before the walls of Alexandria, and then the greatest trade center of the world, nine hundred and seventytwo years after it was founded by Alexander the Great, 
fell into the hands of the Moslems. They had sacrificed twenty-three thousand men in this siege. Many of the Christians escaped with the Byzantine fleet, while the rest of the Greek garrison marched beyond Meks into the mountains of the Libyan Desert. Amru followed them into the desert to make sure of their final defeat. Then a strange thing happened, for hardly had the Moslem chief disappeared in the desert hills of Libya, when the Byzantine fleet came back, put the Moslem garrison to the sword, and once more hoisted its flag over the metropolis. Still the temporary success did not last long. Amru returned, and, without much difficulty, in 640 A.D., made Alexandria the Moslem center which it is to this day.

Christian historians have made much of the burning of the Alexandrian library, but there is some wellfounded doubt as to the historical correctness of this. The story goes that John Grammarian, a well-known Coptic philosopher of Alexandria, begged from Amru permission to maintain the library for his own use, in order to continue his studies of Moses and Aristophanes, on whom he had already written voluminously. The general sent to Omar in Mecca for instructions what to do with the library, and the well-known answer came back-

"The contents of those books are in conformity with the Koran or they are not. If they are, the Koran is sufficient without them; if they are not, they are pernicious. Let them therefore be destroyed." 


\section{AFRICAN HEROES AND HEROINES}

It is very probable that a number of the more valuable manuscripts were carried away, before the fall of Alexandria, to Constantinople, and may be found there when some of the hidden mysteries of Stamboul give up their secrets.

The riches of Egypt were of great importance to the poverty-stricken Arabs, and the fruitfulness of the land during the famine in Arabia alleviated the threatened danger of starvation there. Tradition tells of a food caravan sent from Egypt, a caravan so large that the first camels reached Mecca before the last left Egypt! Those were the days when the Crescent faith was young and vigorous, and many things were done by the Moslems which no one would expect from them to-day. Among other things, Amru opened again the Trajan Canal between the Nile and the Red Sea, to improve the communication between the mother country and the newly acquired provinces.

Time fails here to tell of the other fights between the Moslems and the Greeks in North Africa, thrilling though we should find many of the incidents of that war. The weakness of Abdallah Ibn Saad, who twice replaced Amru and twice had to give way to him when the Greeks were victors, appears at the last siege of Alexandria, and during his battle with Gregorious, Prefect of Cyrenaica. Time fails also to tell of Abdallah's later conquest of Nubia, where he defeated the Christian king, and exacted an annual tribute of Ethiopian slaves.

For some decades the attention of the Moslems was directed towards Byzantium, but the sixth Kalipha, 
Moawyah, determined first to send his flag into the various states of North Africa. Acbah Ihn Nafer El Fehri was put in charge of I0,000 horsemen and marched into Barka. The city of Cyrene was taken and destroyed. "Westward Ho!" sounded the clarions of the desert tribes. Seventy miles south of Carthage, Acbah laid the foundations for a new Moslem city-Kairouan, the Holy. In the open square of Kairouan he drove his spear into the ground, calling out to the tribes, "This is your caravan" (Caravan = Kairouan). Kairouan became in later days one of the chief Mohammedan centers of North Africa, and, with the Azhaar in Cairo, and the University of $\mathrm{Fez}$ in Morocco, formed the triumvirate of Moslem colleges.

Acbah was a great conqueror. He marched from Numidia to Mauritania (Tunis to Morocco); he rode his war-horse into the African sunset-sea (the Atlantic), and, lifting his sword to heaven, exclaimed, "Ya Allah! Did not the deep water prevent me, still further would I carry the knowledge of thy law, and the reverence of thy holy name!" Acbah's march through North Africa had been too easy. The Berber and Greek population was far from being subdued. Ibn Cahina (Son of Cahina), a Berber chief, lay in wait for Acbah at a place called Tahuda (A.D. 682). Like avalanches the Greek and Berber tribes rolled down the mountain sides upon the Moslem host. Neither side asked for quarter. The Mahommedans broke their scabbards, said their prayers, and with the cry, "To Paradise!" advanced towards their enemies. Acbah was the fast to fall, and none of his men escaped. 


\section{AFRICAN HEROES AND HEROINES}

It was in the year 699 A.D. (the $77^{\text {th }}$ year of the Hegira) that the final war commenced between the Crescent and the Cross for North Africa. John, the Greek prefect, tried in vain to defend Carthage against Hassan Ibn Annoman, with his forty thousand chosen warriors. Carthage went up in flames.

And now we come to the greatest figure in the history of that period,-Cahina, ${ }^{1}$ the mother of the Greek Berber chief who had defeated Acbah.

Cahina, or as she was known among her Moors, Dhabba, is reported to have been the daughter of the prefect Gregorius. The people throughout North Africa reverenced her as a saint and a prophetess, and as one man the tribes of the northern parts of the African continent-Greeks and Jews, Moors and Kabyls-rallied under her standard. Slowly but surely Hassan was driven back towards Egypt. It looked as if nominally Christian North Africa would after all be saved. But Cahina, well versed in the wisdom that comes from a knowledge of history and the study of God's dealings with the children of men, knew that the wealth of North Africa was North Africa's weakness, and that the unmoral flabbiness of a degenerate people could not withstand the vigor of the attacking forces. She called together her princes and her rulers for counsel in the great palace of her capital, Constantine. She prepared a feast for her faithful followers. Around her were the wise men of the nations by whom she was acknowledged as queen. Sounds of revelry and rejoicing

${ }^{1}$ See Washington Irving "Mahomet and his Successors," and Condé "The Arabs in Spain." 
filled the hall, for had not the Arab hordes been driven back to Egypt! White-haiked chiefs of the Imoshag, white-haired men from the west coast, white toga-ed prefects and pro-consuls from Byzantium and Rome sat before her who, alone in the assembly, sat sad-eyed, gloomy forebodings casting shadows over her strong fearless features. The night drew on. Louder the hoarse cry of victory rolled upward to her on her throne from the many-tongued multitude that formed the great assembly; when suddenly she arose and with far-sounding voice in solemn tones called to her people-

"My children, old I am, the mother of your leaders, and I love you all more than you can ever love me. Listen then to what the past has taught me. Though Hassan has been driven back to Egypt, though Acbah, his predecessor, perished before the army of my son, these Moslem desert robbers will not desist. I know full well that they will come again, and once more try with greater force than ever to put the yoke of slavery on our necks, and compel us to renounce our faith in Christ. But here I swear to you that I will not renounce that faith to save my life, for life is not the greatest good. One hope remains-to take temptation out of the reach of these despoilers of the rich lands of the world. Why did Egypt fall a prey to them? Because the land was rich, the people weak. Why did the Kaliphas set their eyes on Byzantium? Because it is the richest city in the world. Let us agree to-night so 


\section{AFRICAN HEROES AND HEROINES}

to deal with our wealth that from henceforth no gold and no marble-columned palaces shall tempt poor fanatics to come again into our land for booty. A month from now let every man and woman in our land light such a bonfire of all property, whether house, or park, or personal apparel, that poorer we may be than even Arabs. Let all the palm groves be cut down; the olive gardens, fig trees, vines and other fruit trees be destroyed. Let all our gold be buried in the mountains. Let us lay waste the cities and the towns, and then withdraw ourselves southward to the desert, for a while. So shall the Moslems, coming back next year, find nought to draw them onward,- - nought to tempt them, and we may yet live free and seek forgiveness for our sins of soft living. Save us Christ from slavery."

So it was done. The land was made a wildernessbut in vain.

Musa Ibn Nosseyr, a man of sixty years of age, was now appointed in the place of Hassan to carry out the plans of the seventh Kalipha, Yezid (who began to reign in 680 A.D.). Some say that Hassan himself was the victor of North Africa, and died of a broken heart when his successor was appointed, but there is little doubt that it was Nosseyr who completed the devastation of North Africa, and carried away hundreds of thousands of women and children into slavery.

But let us follow the story of Cahina to its close.

She herself led her troops against a strongly reënforced Mohammedan army, and was defeated. She 
was captured and taken into Egypt. The victorious column was lined up in great parade, and Cahina was brought to the presence of her conqueror.

Her snowy head was held erect. Tense was her face with its aquiline nose. Her eagle eyes gazed fearlessly upon the host before her. The Moslem mullah then approached her- "Thou woman, once a queen, but now a prisoner, art herewith asked,-

"Wilt thou renounce thy faith, forswear thy creed (blasphemous before Allah) that Christ, the son of Mary, was his son? Wilt thou recant and believe no longer that Isa, son of Miryam, was crucified by the Jews? Wilt thou repent, swear allegiance to the Kalipha, and repeat after me, 'La Illaha ila Allah wa Mahomet errassuhl Allah' (There is no god but Allah, and Mahomet is the prophet of Allah)."

Those sad features shone as shine the sparks struck from a flint by steel, as from her lips came, quick and sharp, the words, "Far be it from me that I should deny the Christ who gave His life for me. Away from me, thou servant of Iblis, thou follower of the Crescent; thine the sign of night, but mine the sign of righteousness! Out upon you, ye robbers, who enslave the bodies of your victims! I count it a privilege that I can show you how a Christian dies. Come on! Finish your work! Here I stand before you many thousand men,-a woman, winning victory. 'Christ is my life and death my gain." "

They slew her, and she died.

And for a thousand years North Africa was comatose, drugged by blood and fire, while slowly but 


\section{AFRICAN HEROES AND HEROINES}

surely the sand of the Sahara Desert encroached upon the once fruitful plains of the Cyrenaica, of Barka and of Mauritania. The palaces lay in ruins; flames had reduced the libraries and colleges to ashes; the churches had crumbled to dust; the leaders of the nations were dead or had fled; the women had been carried off as slaves, and the remaining rabble, despised by their conquerors, feebly echoed their "Allahu Akbar" (Allah is greater).

God in His Providence prefers unbelief to hypocrisy. The nominally Christian peoples of North Africa had gone through His mill. They were ground to dust. The hurricane from the East had blown upon them, and history for a millennium knows them no more. 


\section{CHAPTER II}

On the Ubangi and the Niger, Graham Wilmot BROOKE, a soldier of the king, and then a Soldier of the King of kings. 


\section{GRAHAM WILMOT BROOKE}

I 865 (Feb. 23rd) He was born-the eldest son of Lieutenant Colonel Robert Wilmot Brooke.

I $882 \mathrm{He}$ was influenced by talks with General Gordon to think of foreign missionary work in Africa. He was then a medical student at St. Thomas's Hospital, London, Eng.

I885-9 After he had left the British army (for which he had been educated) he traveled in Nigeria, Senegambia, and on the Mobangi-Congo, endeavoring to get into the Sudan as a missionary.

I 889 Joined the Church Missionary Society of England, and the Rev. J. A. Robinson led the first missionary party of the C. M. S. into the West Central Sudan.

1890 After three months on the Niger he was invalided home. I89I (May 4th) He was back again on the Niger with two Cambridge graduates.

1892 (March 5th) Brooke died at Lokoja on the Niger.

"As truly as Hannington gave his life to purchase the road to Uganda and-has won it, so truly has Graham Wilmot Brooke laid down his life that Christ may be preached through the length and breadth of the Sudan. And shall he not win it too?"

Church Missionary Intelligencer, May, 1892. 


\section{CHAPTER II}

Over a thousand years have gone by since Cahina died, and we have come to the days of modern Christian missions in Africa.

"Look, white man, slaves!"

A gang of emaciated men and women, the slave fork on their necks, their skin colored ashy gray from fear and famine, their feet weary from long wandering, their faces expressionless, their eyes hopeless, dull, watery-some twenty or thirty human chattels-toiled along the bush path, prodded onward by the points of spears.

"Look, white man, slaves! The bad people down the river buy them for chop," (food).

Graham Wilmot Brooke, an officer in the British army, had heard the call of the nations in the shadows, and had dedicated his life to their Christianization. After many months' travelling he had found his way into the very heart of Africa, and on the northern bend of the Mobangi looked longingly into the lands of the Central Sudan. But his supplies had given out; he was some five hundred miles beyond the furthest outposts of the white man; the tribes before him were inimical, and his road was closed. He had spent the night in a native hut. He was just recovering from an attack of fever when his attention was drawn to the ghastly sight. 


\section{AFRICAN HEROES AND HEROINES}

"Look, white man, slaves!"

Sights such as this had been familiar to David Livingstone.

Denham, fifty years before, riding along one of the great highroads of the slave-trade near Lake Chad, was wakened out of his day-dreams one afternoon by his horse stumbling, and looking down found that his mount had crushed under foot a human skull-a reminder in the desert of the slave trade. He tells us that for many days his mind revolted at his horse's sacrilegious faux pas-but then, the horse was but a horse.

"Look, white man, slaves!" Some thirteen years ago the writer when travelling in Tripoli, was one morning startled by the same words coming from the lips of one of his companions. He was journeying southward on one of the five highroads of the desert, each of them two thousand miles in length. ${ }^{1}$ Milleniiums of travelling of the caravans have, in places, worn into these roads deep grooves through solid rock, and yet it was bare human, and unhoofed velvet-padded camels' feet that made these grooves!

Along the road came a caravan of three hundred camels loaded with ostrich feathers, ivory and morocco skins. Slowly they passed, Arab drivers singing songs while carrying their loaded flintlocks handy for defense.

${ }^{1}$ The first one leading from $\mathrm{Fez}$ in Morocco to the desert city Timbuktu, the second from Algeria and Tunis to the Niger, the third from Tripoli to Lake Chad, the fourth from Bengazi through the cluster of the Kufra Oases to Wadai, and the fifth one from Alexandria in Egypt through the oases of the Libyan Desert to Darfur. 
"Look, white man, slaves!" A string of little girls, footsore, bodies of skin and bone, hardly able to trudge along-"These are not slaves here in North Africa? Why, there is a British consul in Tripoli! They cannot trade slaves here!"

"Why not?" answered the writer's companion. "They take them to the gates of Tripoli and at nighttime distribute them among the houses of rich Arabs and Turks, and, when convenient opportunity offers, send them across the Mediterranean to Constantinople and the cities of Asia Minor, into the Harams."

There is no other modern religion in this world of ours that, like Islam, defends slavery.

"If thy neighbor will not be converted, enslave him," 1 says the Koran. "It has not been granted unto a prophet that he should possess slaves until he has made a great slaughter of the infidels of the earth." 2 Wherever Mohammedanism has held undisputed sway, slavery has always been rampant.

For many years two valuable products of Central Africa formed the staple export of the slave traders. These were known as black and white ivory, and "black ivory" was slaves. Slavery is abhorrent to any one interested in the welfare of mankind (as of course all missionaries are) - abhorrent the maltreatment of mentally or physically weak people, the enslavement of them by dominant races, the abominable deeds perpetrated in carrying out slave raids, and the culminating horror in trading such slaves, as food, to the Congo cannibals.

\footnotetext{
${ }^{1}$ The Koran, page 375, Sale's translation.

${ }^{2}$ Koran, page I30, Sale's translation.
} 


\section{AFRICAN HEROES AND HEROINES}

Of their religion and of these people H. G. Wells says in his book, "What is Coming?":

"The Arab religion and culture lie already like a net over black Africa. No other peoples and no other religion can so conveniently give the negro what is needed to bring him into the comity of civilized people."

Either H. G. W. fails utterly to appreciate the character of the Arab religion, or, in the name of Livingstone, Lavigerie, Wilmot Brooke and many others, I say, Out upon that man who dares to call himself a Christian, and will unblushingly declare that Mohammedanism is suitable for Africa! The world war has produced many weird phenomena, but to have a man like H. G. Wells put forward such a statement is inexcusable. It might have been made by the Chief of the Sinnussi, the Mahdi, or the Sheich ul Islam, but what shall we say to such words coming from the pen of a man who poses as a Christian interested in philanthropy! The writer has lived among the Arabs, worn their clothes, for months spoken nothing but Arabic, and has the privilege of counting many of them as his personal friends, but all these friends know how utterly he disagrees with them in their views of slavery, the treatment of women, and their morality. The Arab is brave: he is a man: but his religion is no good. There is not a single country where Mohammedanism has been dominant for any length of time in which any advance of civilization can be traced to that religion. Need one refer to Turkey, Persia, Asia Minor, Pales- 
tine, Arabia (once called Felix-the-Happy), or Morocco, or Tripoli? In Algeria, Tunis, and Egypt it is the strong hand of the Nassara (Christian) that is slowly but surely undermining the influence of the Crescent faith, thus making it possible for these countries to advance.

Brooke stood before his hut in the heart of Africa, and looked at the string of slaves.

He stalked up to the slavers, and called upon them to release the slaves, saying he would give them all he had. Armed with guns and swords, a number of these hunters of human game crowded round him, flourished their weapons in his face, and declared they would kill him or sell him too.

"Children, children! Why so unruly? Why kill me? There is nothing to be got through killing me except perhaps trouble, for all the white people will be angry with you when they hear of it. Come now, let me have your slaves, and I will let you have everything I have except my clothes." But only wild shouts answered him. Some of their relatives had in days gone by had trouble with a white man whom they called "Bula Matari" (the Rock-Breaker) on the Congo, the man who was known among white people as Henry M. Stanley. Bula Matari had fought their people and liberated many slaves, and here was another white man interfering with them. "Cut his throat," shouted one, but this was easier said than done. Brooke showed his empty hands. There must be witchcraft behind this; otherwise how could this white-skinned, ghastly-looking stranger dare to inter- 


\section{AFRICAN HEROES AND HEROINES}

fere with them? By this time the leading trader had come up from the rear. He pushed aside his companions, glared at Brooke, and using Brooke's servant as interpreter, asked, "What does this man want?"

"He wants your slaves."

"All right. How much is he going to pay?"

"He will give you all he has except his clothes."

"I don't want it. If I meet other white men they will say I robbed him, and I shall have trouble. Let him go on his way and I will go on mine." And in spite of Brooke's angry remonstrances, in spite of his pleadings, in spite of all he could say or do, the caravan moved on. He was pushed aside, and through the long grass trailed the last of the victims, driven onward by the lashes of the hippo whips.

"O God! How long is this horror going to last! How long will selfish, so-called Christian governments in Europe claim spheres of influence in Dark Africa, and in their spheres allow the Moslem traders freely to continue the abominations of their slave-raids!"

Three times did Brooke try to get into the Sudan; first from Tripoli in North Africa he attempted to cross the Sahara Desert and failed. On the second journey we have seen him far inland on the Mobangi, on the borders of that great Sudan, nearly as large as the United States, - unreached by Christian missionaries.

Depressed and downcast he returned to Europe, seeking for fellow-workers who would dare to join him in his efforts to carry the gospel to the great land of darkness. The word "Sudan" comes from the Arabic 
"Sud"-"Sawad" (dark-black), the "Land of the Blacks," or "The Land of Darkness." Brooke's message to the students and young men whom he met merited a better response than it received. "Come on, men," he would say, "we must get into this Sudan with the gospel."

Read the substance of his messages.

"Travelers have crossed the Sudan in all directions. They have gone at the risk of their lives. Many of them, like Mungo Park, have died while exploring it. They have left their tracks and traces all over it; but the missionary of the cross has never entered its kingdoms. The Arab has gone there. He has conquered and killed, and boasted of Allah and Mahomet, and multiplied houses and wives and slaves: but the messengers of the cross have shunned the region. Only a handful has dared to enter it. Merchants have gone there; gold-seekers have gone; hundreds of each are gathering the riches of the land. There are scores of steamers on the Niger. The Royal Niger Company alone made two hundred treaties with the Niger chiefs and potentates, but the missionary of a Higher Power and a nobler enterprise has not yet won those lands for Jesus Christ. There is just a handful of missionaries on the Lower Congo, but in the Central Sudan, along the Upper Benue, around the vast overflowing waters of Lake Chad, in the mountains of Adamawa, in the plains of Wadai, in the rugged ranges of Darfur, in the deserts of Kordofan, among the teeming millions of the Sudan proper, no missionary is found, 


\section{AFRICAN HEROES AND HEROINES}

no Gospel is proclaimed, no Bibles are scattered, no voice is raised to cry 'Behold the Lamb of God, which taketh away the sin of the world!'

"The men of the world are the heroes of the Sudan. Travelers have been heroic. Distance has been no bar to them. Disease and death have proved unable to affright them. Neither love of friends nor fear of foes has been able to dissuade them from their fixed resolve to open it to the knowledge of the world, and bring its people into contact with the civilization of surrounding lands. But the heralds of salvation have almost wholly forgotten this mighty heritage, a host of heathen nations. They have left them all these ages to the reign of unmixed darkness and unmitigated depravity.

"We plead for these neglected ones. We raise our voices on their behalf. They cannot speak for themselves. Distance makes them dumb. Strangership silences them. They wander in moral midnight. They know not what they do. Year after year, age after age, they fall and perish as though of no more worth than the withered leaves of autumn. They have fallen by millions and none have cared for them. Torrid sun and sweeping rain have bleached their bones, or blanched their sepulchers. Melancholy winds have moaned their requiem. Relentless Time has rolled over their generations the billows of oblivion. They have perished from the earth, gone into a dark and dread eternity, without ever having heard of Him who died and rose that men might live, Who was lifted up from the earth to draw all men unto Him, and who 
cries aloud to a ruined and redeemed humanity, 'Come unto $\mathrm{Me}$, all ye that labor and are heavy laden, and I will give you rest.'

"We plead for the neglected millions of the Sudan. We say to the church of Jesus Christ, 'Behold them! They are our brothers and sisters in a common humanity. They are one with us in sin and ruin. Let them be one with us in the knowledge of salvation. Awake, O selfish, sleeping, and forgetful church: arouse thee to thy neglected duties; fulfil thy solemn mission; bear thy testimony and send forth thy sons; proclaim thy glorious message; gird thyself and give thyself, in the name of Jesus Christ, to the tremendous task of evangelizing at last this greatest and most populous of all the wholly neglected and benighted regions on the surface of the globe.'"

The only missionary society at work on the borders of the Sudan in Brooke's day was the Church Missionary Society of England; so he joined that Society and, in $\mathrm{I} 889$, left with his young wife and three other missionaries to go to the Niger, hoping to get into the Sudan by this third gateway at Lokoja, where the Niger and the Benue meet.

The Rev. J. A. Robinson, a missionary at the Church Missionary Society station there, welcomed him, but hardly had Brooke arrived when Robinson fell ill with a severe attack of malaria, and died after suffering for thirteen days, calling out loudly in his death agony, "God be praised." Crowds of natives attended his funeral. 


\section{AFRICAN HEROES AND HEROINES}

Then Brooke's wife fell ill and another lady. He sent them home to save their lives. Then Brooke himself caught fever. He had struggled and worked; he had written, and talked, and prayed; but, like many of the other great pioneers of Africa, he himself was not permitted to see the work accomplished.

In his diary of this time we find the following entries :-

"Sept. 7 th, I 889. Down again with hæmaturic fever -fifth attack. Major MacDonald very kindly sent me up a supply of wine. Probably should not have survived without this.

"Sept. I 2 th. Sufficiently recovered to lie out on the verandah. Had five visitors-four of them Mallams. Hamza is flippant on eternal things, and always begins to hum the Koran if I begin to question him on some searching question. To-day he brought a Mallam from the north-a nice fellow, who said he had heard in his town that there was an Arab at Lokoja, come from Arabia; and going to Musa's he had seen me sitting in the council, silent, in a blue robe. Inquiring about me later, he had learnt I was a European, and so had asked Hamza to bring him. He listened with eager attention as I pressed upon him that as he did not even know the meaning of the Arab's Koran, he was like one groping in the dark. I then read him all I had written of my tract on the need of an atonement, to which he listened eagerly. A few days later I heard this same man say, in a low voice, to a friend:- 'I heard all the words on the paper, and, as I heard them, 
my blood grew cold; and so would other men's do through all the country if they were made known.' As I heard it I felt such a thrill of hope as Gideon must have had as he listened to the Midianite's dream.

"Three more visitors in the afternoon. I read them the tract and was overjoyed to hear their explanations and eager questions at the crucial points.

"Sept. 23rd. Farewell for a few months to Lokoja and its many people."

A native called Joshua Williams (who afterwards became a leader in the missionary work of the Church Missionary Society in Northern Nigeria) nursed Brooke, and when this Great Heart was troubled, saying to Williams, "Why does God send so much sickness and take away some when they seem most needed?" Williams reminded him that God needs some to sow and some to reap. At this Brooke smiled delightedly, and was perfectly content to live or die as God willed. "If it is difficult to get a coffin, put my body in a native mat and bury me," he said to Williams. He also gave him the texts he was to put on his grave (and they are there to-day) - "In a moment, in the twinkling of an eye, at the last trump: for the trumpet shall sound and the dead shall be raised incorruptible." Brooke was buried by the side of Robinson.

Thus died one of the greatest pioneers of Africa, who three times knocked at the gates of the Sudan and while knocking yielded his life, a soldier of the king, and then a Soldier of the King of kings.

Two months before Brooke's death Bishop Crow- 


\section{AFRICAN HEROES AND HEROINES}

ther had died. The sickle of the harvester was busy in West Central Africa. Then Bishop Joseph Sydney Hill was appointed to West Africa. He went out with his wife and seven companions. Both he and his wife fell ill with fever. He said to her, "I am going home," and she replied, "I think we are going home." With the exception of one lady who was sent home to England every member of the party that accompanied Bishop Hill died.

The last one, Mr. Watney, whom the natives called Ogboputalunaozo (the slave that his master kept when he sold all the rest), was also taken, and only Miss Maxwell remained alive, the one who had been sent back to England. She recovered and has since returned to Africa and done good work there.

Here, my friends, you who are interested in foreign missions, here you have a picture of what most of the leaders of foreign missionary enterprise have had to face-heroic efforts, disappointment after disappointment, and then death-death which for them was a greater reward than the adulations of people at home that might have been theirs had they been successful in life. 


\section{CHAPTER II (Continued)}

A Slave who became a Bishop, Crowther, the African Saint 


\section{BISHOP SAMUEL ADJAI CROWTHER}

I 806 Born at Oshogun (Southern Nigeria).

I82 I A kidnapped slave.

1822 A rescued slave.

1823 A mission schoolboy.

I825 A baptised Christian.

1826 A college student.

I 828 A teacher.

1843 A clergyman.

1845 A missionary to his own country.

1857 Founder of a new mission.

I 864 The first negro bishop.

I89I (Christmas morning) He walked to church for the last time.

1892 (January Ist) The Bishop was buried at Lagos.

"Where is the parallel to such a life?" asks Eugene Stock. 


\section{CHAPTER II (Continued)}

"Hurrah! Hurrah! We bring the Jubilee!

Hurrah! Hurrah! The flag that makes you free!

So we sang the chorus from Atlanta to the sea,

While we were marching through Georgia."

IN the very heart of Africa the present writer, in his tent early one morning before daybreak, heard to his amazement the sound of whistling,-the whistling of the marching song of the Grand Army of the Republic. He knew there was no one among his people that could whistle that. He himself had not heard it for years. Dropping his comb and brush he stepped out of his tent to welcome the American, for it was many days since he had seen a white man. But there was no white man! The members of the Safari (caravan) were sleepily crawling out of their grass huts: the cook-boy was trying with his mouth-bellows to rekindle the embers of last night's kitchen fire; the head-men were busy with the loads. There was still placid peace in camp before the bustle of the start-but no American!

"Hurrah! Hurrah! We bring the Jubilee," came from the long grass yonder on the right, when-out stepped a native, a raw pagan, who had come from the village near by, probably sent by the villagers to see what this crowd of people was doing in the bush, for they had noticed the light of the camp fires the 


\section{AFRICAN HEROES AND HEROINES}

previous evening. "Hurrah! Hurrah! The flag that makes you free!" as he marched up to the first huts of the camp. Perhaps he belongs to the expedition of an American traveler? The white man therefore sent one of the servants to call the native. The native came.

"Good-morning," said the white man, but the native shook his head. He did not understand the language. An interpreter was found among the men of the caravan, and the native was asked whence he came.

"I came from my village yonder behind that hill."

"From your village?"

"Yes." "Then you do not belong to the caravan of a white man?"

"No, I have never seen a white man before."

"But where did you learn that tune?"

"I do not know. Probably I heard some one else whistle it."

And without doubt that tune must have gone from lip to lip until it reached the heart of Africa. It may only be an exceptional case that a number of natives should take up a tune such as "Marching through Georgia," but it is certain that the African's ear is far more attuned to music and harmonies than that of the average white man. The choir choruses of the Jubilee Singers of the Fiske University in the Southern States included the finest voices, and their nuances and intonations were the most wonderful that could be heard anywhere.

The writer's native followers on a journey across Africa carried no less than eighteen different rudimentary musical instruments with them-instruments that 


\section{BISHOP SAMUEL ADJAI CROWTHER 45}

were native-made and primitive, but the boys got no end of enjoyment out of playing them. There were zithers, and flutes, and fifes; there were drums, and stringed instruments; there were antelope's horns and goat's horns used for signaling; there were pipes of Pan and rattles.

The African greatly loves music, and with his vocal organs is usually able to reproduce difficult harmonies. The formation of his mouth cavity and the strength of his vocal chords enable him to sing as few white men can sing,- - and he is nearly always singing. The Caucasian race has, with the gift of logical thinking and reasoning, produced a civilization dominated by the exact sciences. The African, when his day comes, and it will surely come, will develop music.

Dr. Frank Crane tells us of an experiment that is being tried in New York. A company of negro actors are attempting a serious dramatic performance of plays written specially for them, and supposed to be peculiarly adapted to their genius. "If the highly cultured and wholly unprejudiced foreigner were to look for the most interesting theater in the city, he would find it here," says Dr. Crane, "for here are real human beings trying to express themselves, and not to depict borrowed emotions. It is the best kind of art. They are revealing the soul of the people. They are real artists. There are certain qualities of spirit, certain shades of passion and of conscience which the negro can portray better than any other race. There is a pathos, a tenderness, a poetry of loyalty and genius of sympathy wherein the African excels. He has none 


\section{AFRICAN HEROES AND HEROINES}

of that offensive and hard pride that mars the Caucasian. In the great democracy of art the negro is welcome. I think the negro is by nature the race best suited to Christianity."

For many years the writer has seen in the African rudimentary gifts and qualifications that when developed will be a contribution to the cosmos of mind and soul-life that may not be despised. North Africa, with her church fathers and eight hundred bishoprics, and Central Africa with her "miracle of modern missions" in Uganda should give Caucasian Christians food for thought.

What lies dormant in the African and might in him be awakened, we shall see from the following true lifesketch of a negro-a negro by the name of Adjai. Adjai's father was a weaver in a small town called Oshogun in Yorubaland. He was one of the head councilors of the village. Adjai's older brother was called Bola, who took care of the farm while his father was busy in the town council. Adjai as a small boy was much interested in chickens and accumulated quite a number of cowrie shells, and soon he was able to have his own plot of ground, but it was seven miles away from his home. As in other countries, in negroland boys go in bands, and Adjai was the leader of some forty chums of his.

Of the slave raid in which he was caught, he says in his diary, "We were preparing breakfast, when at 9 o'clock, a rumor was abroad in the town that the enemies had approached with the intention of hostility. It was not long after when they had almost surrounded 
the town to prevent any escape of the inhabitants. The town was rudely fortified by a wooden fence about four miles in circumference, containing about 12,000 inhabitants, and producing 3,00o fighting men. The men were surprised. The enemies entered the town after three or four hours' resistance. The women with their children ran away. They were overtaken and caught by the enemies by a rope noose thrown over the neck of every individual to be led, in the manner of goats tied together, under the drove of one man. I was thus caught with my mother, two sisters, one infant about ten weeks old, and a cousin. The last time I saw my father was when he came from the fight to give us the signal to flee. I learned some time afterwards that he was killed in another battle.

"Our conquerors were Eyo Mohammedans. We left the town to the mercy of the flames, never to enter it or see it any more. At a town called Nehi, where the Moslems had their headquarters, twenty miles from Oshogun, the slaves were divided among the warriors. My sister and I fell to the share of the chief." Then he was bartered for a horse, and in twenty-four hours he was the property of three different persons. About three months later he was driven with a number of boys, chained neck to neck, to the market town of Ijahi. "Several nights I attempted to strangle myself, but had not courage to close the noose tight so as to effect my purpose. I next determined that I would leap out of the canoe into the river when we should cross it on our way to the coast country, where I knew I was to be sold to the Portuguese." Then he was sold again. 


\section{AFRICAN HEROES AND HEROINES}

"After having arrived in another town I renewed my attempt at strangling, several times at night, but could not effect my purpose. It was very singular that no thought of making use of a knife ever entered my mind. However, it was not long before I was bartered for tobacco, rum, and other articles. Then I was traded to Eko, a place where there were a number of Portuguese. I had never seen, until then, the face of a white man. It was with fear and trembling that I received, for the first time the touch of a white man who examined me to see whether I was sound or not. Men and boys were chained together with a chain about six fathoms in length, drawn through an iron fetter on the neck of each individual, and fastened at both ends with padlocks. Thus we were kept for nearly four months -when one night we were sent in canoes from Eko to a vessel called Esperanza Felix, which immediately sailed away. The crew being busy in embarking us, had no time to give us either breakfast or supper. The next day was the 7 th of April, I 822 ."

"O Mother, O my Father!" came from the lips of the twelve-year-old boy in the hold of the Portuguese slave ship. But Father did not answer. He had been slain by the Moslem in the slave raid. True, his mother and sisters had escaped, but little Adjai did not know this.

"O Mother, Mother! We were so happy, so happy!" Slave chains clanked on the wrists and ankles of the boy and his hundred and eighty-three fellowslaves.

"Why did they not kill us? I wish I were dead. 
Have these white devils no heart? What have we done to them-we poor black children of Yorubaland? Why should they burn our village? What do they want with us? Are they going to make medicine out of us-medicine to help them in their witchcraft?"

Stolid-eyed, a young man squatted brooding by his side; on the other side and behind him women wailed, "Woe! Woe! Woe to us!"

They knew the white Moslems in the north were their enemies, but they thought that the white people of the Coast were their friends, and now the whites of the north had sold them to the whites of the south, and they were on a ship on the great waters, not knowing whither they were carried. Matters could not be worse, and when utter despair had laid hold of them, relief came as suddenly as the trouble had come during the last moon.

A gunshot! Then excitement on the deck overhead, cries, curses, loud talk, and down the steps into the hold of the ship came white men in uniform-white men who spoke a language different from the ship's people. They signaled to the slaves to come on deck. Hesitatingly the frightened black people obeyed, wondering whether they were to be thrown overboard, but instead the padlocks were unlocked and the chains taken off them. They were told to go into the small boat that lay alongside the larger vessel, and in batches they were rowed across to another large sailing craft, larger even than the slave vessel on which they had been. Slowly, their eyes full of fear, their limbs shaking, they climbed up the ladder on board the new boat. 


\section{AFRICAN HEROES AND HEROINES}

In later years Adjai told how the cannon balls that lay on the deck of this vessel looked to the slaves like cutoff human heads, and they wondered whether this vessel was to be the end of their life's journey. They were sure some further trouble could not but come to them and that all were to be sacrificed; true the new white men of this ship had no whips to drive them with, but gave them water to drink and then fed them.

"Perhaps they want to fatten us up before they kill us and perhaps they will eat us," and so they ate sparingly.

When all were gathered on the fore deck one of the white chiefs of the boat came up to them, and, $\mathrm{O}$ wonder of wonders! spoke to them in Yoruba.

"Children," he said, "you are free." At first the statement could hardly be believed, but as the truth of it sank into their distressed and troubled minds, rejoicing broke out. On their knees they clasped the hands of the speaker, they touched his coat, they smiled up at him, they almost mobbed him.

"Who are you, white man?"

"I am British, and this, a fighting ship, has taken you from the hands of your slave masters, who will be punished."

Their tongues broke loose as the white man left them and they chattered volubly, those older explaining to the younger that these were indeed the good white people they had always heard about, and those black round balls that looked like human heads were not heads at all, but food for cannon. They sat together in groups; sore feet were bandaged and chafed 


\section{BISHOP SAMUEL ADJAI CROWTHER 5 I}

wrists were washed, and when at last the sun set in the great sea in the west, Adjai and his fellow-countrymen looked back upon a most memorable day.

The British man-of-war, the Myrmidon, sailed on throughout the night, and a day or two later reached Sierra Leone. There the liberated slaves were landed, the children put to school, and the older ones helped to find work.

Years went by: Adjai was growing into manhood. $\mathrm{He}$ attended the services of the church of England regularly, and of course the school to which he had been sent was Christian, for the pagans have no schools. In due time our young friend decided to accept the Christian faith, and, living a consistent life, was baptised and given the name of Samuel Crowther. He became so intimate with the British missionaries that they took him on a visit to England. On his return, he was sent to the college at Regentstown, which afterwards was known as Fourah Bay College. By this time his Christian character had matured, and he decided to follow in the footsteps of his white friends, and become a missionary. For some years he taught in the school. Besides receiving Christian instruction he had acquired a wife.

A little girl from his own village who had been captured and liberated with him, and whose name was Asano, had given her heart to the Lord, had been baptised, and was now called Susannah. He married her. They lived happily together, and often talked about how they would love to go back to their people and 


\section{AFRICAN HEROES AND HEROINES}

tell the good news of the Savior, but many years went by before their plans could be carried out.

Some of the liberated slaves had become traders, and, journeying along the West Coast, they heard of a city of refuge that had been founded by friends and relatives of theirs. Their country in Yorubaland had been known as the Egba country, and the remnants of their tribe that had escaped the Moslem slaveraiders had, under their chief Shodeke, built the city, and called it Abeokuta (Understone), for caves among the rocks had been their first hiding places. Two parties of native traders from Sierra Leone set out to visit their relatives in the new settlement. One traveled by way of Lagos, and the other through Badagry. The former party was robbed and had to return, but the second succeeded in reaching its destination. Imagine the excitement in Abeokuta when the relatives whom they had mourned as dead suddenly apeared, rich and learned, telling of what the white man had done for them. The influence which these Christian native traders exerted in Abeokuta was such that the chief of the people asked them to plead with the white men on their return to the Coast and ask them to come to the city and teach all the people the good things that had made their friends such fine, clever men. When the traders came back to Sierra Leone with the call, the missionary society decided to send out Henry Townsend and Samuel Crowther; and in 1845 these two arrived in Abeokuta and began their missionary labors.

One afternoon when Samuel Crowther sat on a grass mat with his books, on his shady, thatched porch, before 
his hut, an elderly man came up the road and saw Samuel reading, saluted him, and commenced conversation. First they spoke together about the books, then about Samuel's work, then about the Mohammedan slave-raiders, and at last Samuel said, "I, too, have had an experience with these evil men, for they slew my father, enslaved me, and whether any of my people are alive I know not."

"What was the name of your village and your people?" asked the visitor. Samuel told him.

"And what was the name of your father?"

When Samuel gave his name the old man leapt from the ground and ejaculated, "Why, your father was my brother!" Now it was time for Samuel to get up.

"Uncle, do you know anything of my mother?"

"Yes," came the reply, "she lives not far from here, and with her are your sisters."

Into the house rushed Samuel, calling, "Wife, my mother is living. I am going to see her." And out of the house he hurried.

"Come, Uncle, come quickly," and both set off at a run, and that same day mother and son were reunited. For twenty-five years they had been apart, he thinking her dead, and she thinking him lost, and now they were together again. His mother had gone through some terrible experiences. She had been sold twice and twice was she ransomed, and even now she and her children were far from safe. Indeed it was not many weeks after that that Samuel's brothers and sisters were kidnaped and brought into Abeokuta for sale. Samuel heard of this and was able to ransom 


\section{AFRICAN HEROES AND HEROINES}

them. To safeguard his mother he brought her into Abeokuta, and there taught her the Christian religion, and within a year she was baptised, taking the name of Hannah.

Crowther's influence in Abeokuta increased. $\mathrm{He}$ paid several visits to another great city in Yorubaland, called Ibadan. This city is known on the West Coast of Africa as "The London of Negro-land." Ibadan and Abeokuta are probably among the half a dozen largest cities in Africa, the others being Cairo, Alexandria, Algeria, Johannisburg and Khartum.

For years Samuel Adjai Crowther journeyed through the lands of West Africa. His influence extended to many districts. In 1854 he led an expedition up the Niger and Benue, rivers then known as the Quorra and the Tsade, with a view to getting into the Lake Chad region. He tells us of his difficulties with the chief at Ibi, of his fruitless attempt to reach the Jukum capital, Wukari (to-day the seminary center of the Sudan United Mission). He paid ten visits to England, where he was greatly honored.

In the year i 864 he was consecrated Bishop.

His difficulties in the administration of his bishopric were due to his goodness of heart. He was noble and true, and thought too well of his fellow-men. His very kindness led him into errors of judgment. In a letter written on the 3oth of January, I884, to the secretary of the Church Missionary Society in London he says, "I would urge the parent committee to supply the Niger Mission with as many European missionaries as they can. The Europeans are better manag- 


\section{BISHOP SAMUEL ADJAI CROWTHER 55}

ers. We shall be content to work under their direction as in former years." It may be yet a little while before the mission Church in Africa is capable of self-government; but, in the history of that Church, one of the outstanding figures will be the first modern black Bishop -Samuel, whose childhood's name was Adjai.

"Mother, they told us in church last Sunday that at the great missionary meeting in Exeter Hall the first black bishop is to preside. I would love to see a black bishop. Mother, does he wear feathers? And has he been a cannibal?"

"No," said the mother to her little English girl, "but he has been a slave. I will take you with me to the meeting. So to the meeting they went. The large hall was crowded with people to hear the annual reports of representatives of the greatest Christian Missionary Society, from China, India, Japan, and also from Africa, and the committee of the society had decided to put their first African bishop in the chair. London fog filled the hall and in spite of artificial light it was difficult to see the people on the platform. Eugene Stock, now the venerable editorial secretary of the Church Missionary Society, took a white cloth and put it over the back of the chair, so that all might see the black head of their chairman.

"O Mother, I see him! He has clothes on like others, but his head is quite black."

"Yes, child, he is an African, an Ethiopian from the Dark Continent."

Slowly the solemn meeting in Exeter Hall moved on. Men told of the child widows in India, of the foot- 


\section{AFRICAN HEROES AND HEROINES}

binding of China, of the savages of the South Seas, of Armenian massacres, and of the Miracle of Christian Missions now being enacted in Uganda. The stately black bishop guided the meeting, now sobered at the serious reports of some men from the ends of the earth, now bubbling over with mirth as some missionary told of the ludicrous happenings among his native friends, - told how some friendly chief had been persuaded by a good-for-nothing white trader to dress his boatmen in frock coats and top hats, that being the extent of civilization he thought suitable for naked savages.

In the seat of honor in the great assembly sat the liberated black slave, humble, though a "Very Reverend Lord Bishop," childlike still, "a man in whom there was no guile." The service was drawing to a close: the white-haired African saint arose, and with outstretched hands pronounced the benediction.

"Mother dear, I would love to have a closer look at the bishop." So Mother waited, holding the left hand of the little child. The streams of people flowed past them slowly as the hall emptied itself.

"Come, darling, we will go up to the platform," and she led her little girl toward the crowd that surrounded the speakers. The twinkling eyes of Samuel Crowther saw the mother and the child, and like the big child he himself was, an understanding feeling of comradeship made him leave the dignitaries of the great assembly. He came down to the little lady on the rostrum, and put out his big black hand. He took the little girl's white fingers between his own and said, "God bless you, 


\section{BISHOP SAMUEL ADJAI CROWTHER 57}

little lady friend." Trustingly the little child looked up into his face.

"Thank you. I am so glad that I have seen you now. Come, Mother, let us go home." And she never forgot her great black hero. 

CHAPTER III

François Coillard of the Barotse 


\section{FRANÇOIS COILLARD}

I834 (July 17th) Born at Asnières-les-Bourges, France.

1836 His father died.

1850 Decided to be a missionary.

1855 Studied at Strassburg University.

I857 (September Ist) Sailed for South Africa.

1857 (November 6th) Reached Cape Town.

1858 (January 27th) Left for Basuto Land.

1872 First Synod in Basuto Land.

1878 At Bulawayo.

I880 (March 9th) Reached Paris on his first furlough.

I882 (August) Back in Basuto Land. Met General Gordon.

1884 Arrived in Barotse Land.

I 896 (June) Second Furlough.

1898 (December Ioth) Sailed for South Africa.

1904 (May 27th) Died at Sefula, and was buried by the side of his wife. 


\section{CHAPTER III}

FrançOIs CoIllard wrote in December, I 898, when on his third journey to Africa, "I am departing for the third time to Africa-poor Africa! Ah, if one could only give oneself to her until the last hour of one's life." (He died on the Zambesi in full activity on the 27 th of May, I904). "I envy Livingstone and the grace which made him die on his knees, praying for Africa. What a man! What grace!"

$\mathrm{He}$ was born at Asnières-les-Bourges in the center of France on July I 7 th, I 834 . His parents were Huguenots. The memories of the night of St. Bartholomew had been handed down in the family. They were farmers, tilling their own soil, worthy people in every respect. François was the last of seven children: his neighbors called him, "Le trop tard venu" (The Come Too Late). He did indeed come too late to know his father, who died when François was but two years old. The first thing the little boy remembered was that he was sent out to tend turkeys. When alone with his feathered protégés he taught himself to read, his only book being one of the Gospels. In I 854 , when he was twenty years old, he entered a seminary in Paris: in I 855 he was a student at Strassburg University. The Paris Mission (the Huguenot Foreign Missionary Society) was giving him his training and would have paid 


\section{AFRICAN HEROES AND HEROINES}

for his course at Strassburg, but he felt that he should not be beholden to them for his secular education. Having sold, therefore, his only possession (a field) for eight hundred francs, he paid this money into the exchequer of the missionary society, and lived on that sum for a year. He wrote to the Paris Committee at the time, "As to the necessary means, as far as that ... I am poor and so are my relations, but in my heart I have already devoted to the Lord the little I possess, and to-day I place it at the disposal of the Committee. It is a small inheritance which I have received from an aunt, and which, sold, will maintain me for at least a year at Strassburg . . . I offer you all I have and ... I shall still be as rich as before."

In later years he said that the months he spent at Strassburg University were the most formative in his life, and it was his life-long regret that he left without taking a degree. His mother heard him preach his first sermon, in his own village in 1856 . He was ordained in Paris on May 24th, I857, and sailed for South Africa on the Trafalgar, a sailing vessel which left during September of that year. After some fearful experiences of calm and storm they reached Capetown, and thence journeyed on to Basutoland on January 27 th, 1858 . This was the period of the Indian Mutiny, and as the Suez Canal was not then in existence, all the trade and traffic from India went by way of the Cape. All the ships plying between England, India, China, Japan, the Dutch Indies, Australia, New Zealand and the Pacific Isles, stopped at Cape Town.

Shortly after his arrival in South Africa Coillard 
was at Wellington, where he had gone to meet a compatriot missionary who had just arrived with his family from the interior. He found a torn and battered wagon, from which emerged some eight or nine children, bare-footed, ragged, hairy and unclean. He was greatly shocked. "Is that what it means to be a missionary!" he asked himself. Till then he had thought his own fastidiousness was worldliness, and to be mortified; but from that moment he made up his mind, come what may, he would never tolerate negligence either in his person or in his household, and he never did. The natives used to call him, "Rama Khethe" (the Father of Neatness). He was a gentleman. His wife used to say, "Even during our long explorations we always had the table laid properly once a day at least, and always paid each other the compliment ' $d e$ fair un bout de toilette' (have a dash at dressing) if at all possible."

The Paris Mission carries on work in two semiindependent native states in South Africa, Basutoland and Barotseland. Coillard spent over twenty years in each. The Basutos are Bantus. Some of them left their country west of Natal, travelling northward across the Zambesi, and founded the Makololo empire in Barotseland about 1825 .

Coillard had only two furloughs in his life. It was twenty years before he took his first, and twenty years between the first and second. He never saw his mother again, who died in 1875 . He wrote long letters to her in large printed character, in order that, with her weak eyesight, she might be able easily to read them. In 


\section{AFRICAN HEROES AND HEROINES}

I 859 he built his first little house. Few young missionaries have had a lonelier life or one of more entire selfsacrifice than François Coillard. He lived on native food during his first three years in Basutoland, was surrounded by an entirely heathen population, hearing nothing from morning to night, and often all night through, but the wild shouts, the din of their heathen dances, their drunken brawls.

An unfrocked French priest who had made Natal too hot for himself came to Basutoland. He was welcomed by a Boer farmer into his house, and, when asked of the happenings of the world, related the fall of Sebastopol. When asked to tell of it he requested to be left alone (in the room where supper had just been put on the table), and he would show them by arranging the furniture how Sebastopol had been taken. They left him alone in the room, and when they came back they found all the food eaten. The unfrocked priest declared that Sebastopol was taken by a ruse just as he had eaten his supper. The Boer angrily turned him out of the house and vowed he would never have another Frenchman in it. Coillard, some time after, sought hospitality at this same farm, when on a journey. But only a seat in the sun, some distance away from the house, a seat usually occupied by natives, was offered him. The Boer farmer brought him some food, but Coillard, young and hot-blooded, refused it and went on his way. Six months later Mynheer appeared at Coillard's house, and Coillard (a native by his side who had been with him at his previous experience with the Boer) turned to the native and asked, 
"How are we going to receive him?" wondering whether he had assimilated any of the Christian teaching. His boy replied, "The missionary will invite him inside to rest, and I will look for the best food we have (what you don't have every day) and cook him a nice meal."

"Bravo," Coillard replied. "That is just what we will do." The Boer was greatly surprised and abashed to recognize his host, but they became fast friends, especially after the Boer had told of his experience with the former Frenchman.

Coillard had a sense of humor; he frequently bubbled over with merriment. On June 25 th, I 860 , he writes, "My poor old Maria is in despair. She was making candles. She filled the moulds and turned her back a moment when she was cooking. In came a dog, and farewell to moulds and candles. The dogs wage continual war upon me. I cannot keep a single egg.

"Letsuele, chief of a little village, came to get a pair of stockings I had promised him. I made a glass of soda-water before him, then Ouèche! Ouèche! Ouèche! I let him taste it, which redoubled his astonishment. 'Fire that freezes,' he said. 'I never heard of such a thing.'

"My two horses, tired of studying geology by day and astronomy by night in the deserts of my new station Hermon, took the key of the fields and made off to the pastures of Leribe." So he had to visit his vast parish on foot through the scorching summer.

His position at times was somewhat difficult. In I 86I he writes to his mother, "I do not speak of our 


\section{AFRICAN HEROES AND HEROINES}

cooking, which is simple, so simple that I scarcely know what we do live on. We have no milk because we have no cows, no vegetables or fruits because we have no garden, no meat because we have no herd and there is no butcher's shop here. Each Saturday Christina depopulates my old poultry yard which indeed will soon be extinct."

He was on most friendly terms with his Dutch neighbors. One day he paid a visit to an ex-President of the Orange Free State, Mr. Hoffman. The object was to procure a cow if possible. "We had passed nearly a year without milk. When I spoke of the price, Friend Hoffman said, 'Sir, the beast cost me nothing. She was born on the place. I often asked myself what can I do for the servants of God, but I did not know their needs. I bless God for making you pass this way. This costs me nothing. See how the Lord has blessed me.' Then he told how, from being well off, he had fallen into distress. His wife, servantless, had herself to grind the maize that supported the large family, and he, crippled as he was, was forced to build. He told of how he met with sympathy and was beginning to get on again when he was elected President, and how, finally, the Lord had visibly blessed him from the time he went back to private life. He counts his large cattle by hundreds and the small by thousands. His wife, angelically sweet in looks and ways, seemed almost as moved as we were in hearing this story of trials past and blessed."

Coillard was very fond of reading, and mice and white ants that destroyed his books gave him a good 
deal of trouble. In 1862 he wrote to his wife who was away for a holiday, "I really think we have killed the blue-stocking mouse! She was frisking about this evening in the fresh air, philosophizing no doubt on the properties of matter, when we pursued her and overtook her-the rogue. How fat and sleek she was! She had nibbled plenty out of your books, poor creature! She was charming, but the thirst for knowledge was her ruin."

Coillard translated a number of fables, among them La Fontaine's, into the language of the people, and these stories are still very popular among them.

His arrival among the Basutos was coincident with the time of war, and when he left them in I 865 another war had begun; a terrific fight was being waged between the Boers and the Basutos, in which the Zulus and the British had also some share. From I 866 to I 868 the Coillards were in exile in Natal, their mission stations among the Basutos having been destroyed. American missionaries showed them great kindness and offered them one of their stations-Ifumi. There the Coillards learned the Zulu language, which was to prove of priceless value to them later on. Coillard preached a good deal at Durban and Maritzburg on Sundays. He became very intimate with Dr. Colenso, the Bishop of Natal. All hope of returning to Basutoland seemed extinct. The missionary committee suggested to Coillard that he and his wife should go to the Mauritius, where a number of French-speaking natives and Creoles promised a useful sphere of work for him. Their stipend at the Mauritius would have been far beyond 


\section{AFRICAN HEROES AND HEROINES}

anything he could hope to receive in South Africa. $\mathrm{He}$ put the issue before his wife without comment, only asking her to think it over. She refused at once to entertain the thought. "When God sent us to the heathen in Africa," she said, "it was for a life-time, and $\mathrm{He}$ will find a way to send us back, if not to the Basutos, to others, and besides we have really taken a vow of poverty, and we must be true to it."

On October I 4th, I 868 , he met the misionary patriarch of South Africa, Robert Moffat. He says of Mr. and Mrs. Moffat, "They evidently have very strong will-power, and would not readily brook opposition. Whatever Mr. Moffat sets before himself he does at once."

From I 869 to 1874 the Coillards were once more in Basutoland. The old chief, Moshesh, welcomed them. Some have called him wily, but others called him wise, for in his day his people flourished. They grew in knowledge and in influence. Had Moshesh but lived longer there is little doubt but that all Basutoland would now be Christian.

For years he had hesitated; then the old king decided to swear allegiance to the Lord Jesus, after some plain speaking by the missionaries. They asked him how much longer he would "halt between two opin. ions."

"Has the witch doctor, with his ghastly worship of the ghosts, proved himself trustworthy in the past? Then follow him. If not-if in your heart of hearts you know that we, messengers of the Christ, who come from far with good news from our Heavenly Father, 
are speaking truth,- -then follow the truth, and the Great God's blessing will be on you."

During this time (it was the time of the war in Europe between France and Prussia) the Paris Mission passed through serious straits. Sometimes it seemed as if the work could not continue. There was no money coming from the homeland, yet fearless faith enabled Coillard to go ahead, and the work developed in those trying times so greatly, that twelve months later (in I 872 ) the first synod of the Mission was called together in South Africa.

About that time his friends, the missionaries from America, who worked in the near-by colony (Natal) came to visit Coillard. The natives heard that they were coming, and without telling Coillard they prepared a surprise party. They killed goats, sheep, and one big ox. Then late at night they came to his house, chanting and singing hymns in chorus. Our friend, who found the noise at midnight somewhat untimely, came to the door, and saw the porch literally covered with food.

"What is all this?" he asked the elders present.

"It is for our friends from among the Zulus. They took care of our father when he was ill, and these are our thanks."

The visitors who never had experienced such a reception, were hard put to it to restrain their tears. More singing, then a prayer, and reluctantly the church members went away-when poor old Damaris arrived with an enormous pumpkin. She had been working in the fields. No one had told her of what was happen- 


\section{AFRICAN HEROES AND HEROINES}

ing, and when the time had come to bring the offering she was empty-handed; so to the fields she ran to get her pumpkin.

"What shall I do with this ?" asked M. Coillard.

"I do not care! You do as pleases you! I am so happy now that I can give a pumpkin. If I had not had one, $\mathrm{O}$ my father, I would have brought a glass of water."

It was in 1877 on a journey into Matabeleland that M. Coillard had one of the most dangerous and exciting happenings in his life. His three ox-wagons were waylaid by a number of well-armed tribesmen, whose chief demanded gunpowder to be paid as tribute. Coillard, who had powder, would not give it, but offered an ox, a blanket and a dog. The powder, and nothing but the powder, would do. The last of his wagons stuck. Wild tribesmen, spears poised, with savage yelling, pressed around, and matters looked as black as possible. A savage, tall and lean, dressed up most weirdly as witch doctor, by trade a prophet but in appearance looking like a court fool, stood at the wagon door and called out, "I am the son of Molimo (God) and I want a suit of clothes, and I will have it,"-with that he snatched some towels. Fono, the brave Christian boy, sat stoically on the box-seat, while Bushman and his friend Eleazar tried to inspan other oxen. Asser and Azael, two other followers of the missionary's, came up (lips white and guns on shoulder), looking determined and prepared to fight.

"I beg of you, my brothers," Coillard said, "put up your guns. Would you shed the blood of those we 
have come to teach! Do not forget whose servants now you are!"

"Yes, sir, but men should die like men."

"No," said Friend Coillard, "we should die like Christians first, like martyrs, if need be. Courage! 'Those with us are more than all that be with them.'"

The first shot would have meant a general massacre. Reluctantly the catechists laid down their arms. The fear-or was it the shame?-of seeing their women who were with them on this journey so much braver than themselves overcame them, but they implored their father to give the bag of powder to the chief. "Please save our children's lives," they begged. The white man hesitated. A case of powder, just enough for hunting, was in the wagon. Now a Banyai native, not knowing what it was, pulled it out. He tried to ascertain its contents and was just about to drive his hatchet through the lid-which proceeding would in a second have solved all the difficulties, and destroyed the wagon and the people. Should he, or should he not consent to give the powder? No! Go back on his own word and prove his weakness? That would never do! The natives started yelling. Coillard shouted, "trek," and, with a violent effort, on lurched the oxen, the wagon moved, and, for the time, the acutest danger lay behind them. A few days later all his oxen were taken by a native chief-Masonda. Summoned by this savage to meet him in the forest, Coillard refused, and sent the chief the following message- "Understand that these oxen are not my property, but that of God whom I serve. Beware of 


\section{AFRICAN HEROES AND HEROINES}

slaughtering them; tend them well, and one day it will not be I who will send for them, but you who will bring them to me, every one." He uttered these words, as he afterwards said, on an impulse, scarcely knowing why. Three weeks later Lobengula's messengers ordered Masonda, as a vassal of the Matabele chief, to restore them at once, and not to presume to plunder travelers himself, as that was Lobengula's exclusive privilege! They were not captured again.

Mme. Coillard had a sun-stroke shortly after. She never entirely recovered from this, and suffered from terrible headaches to the end of her life.

Coillard had great trouble with Lobengula, the Matabele king, who complained that the missionary had entered his country without permission. Several Matabele head-men were sent with warriors to bring Coillard to Bulawayo. The name of this modern city, the capital of Southern Rhodesia, means "The Place of Slaughter," it being Lobengula's camp for some time. Coillard and his people were forced to accompany the Matabele warriors. Their captors pointed to a high mountain covered with huts and remarked casually "There is nobody there now; we killed them all."

"And why?"

"Oh, because they had no ears! They did not give us food when we went to them, so we scaled the crag in the night and slaughtered them."

Coillard was also told that Lobengula had lately lost a favorite wife, a young girl, of course through sorcery. In consequence the witch doctor had indicated 
several villages as the sources of the spell, and all their inhabitants had been put to death-men, women and children.

For three months Coillard was practically a prisoner, being compelled to follow Lobengula about the country, as this thief had no permanent city. At last Lobengula drove the Coillards out of the country. A month's journey, which brought with it some terrible deprivations-and they found themselves at Mangwato, in Khama's country. Khama strongly advised them to go to the Zambesi, and offered to send messengers to Lewanika, chief of the Barotse. What a difference between Khama and Lobengula-a Christian and a heathen chief-the one surrounded by wise counselors and teachers, the other by assassins and executioners.

On their way northward to the Barotse country, the Coillards paid a visit to the Victoria Falls on the Zambesi. Mme. Coillard and her niece were the first white women to see this most remarkable spectacle. Large herds of game and flocks of wild birds peopled the banks. Livingstone had written in one of his journals, not long before, that the antelopes were so abundant that he mistook a horned herd for a forest. Coillard experienced the same illusion.

Here Coillard met with a number of natives who had known David Livingstone. Some of the stories they told had, naturally, a legendary character. Livingstone was the first white man that they had ever seen; he was the best hunter ever known; he healed the sick; he was generous to a fault, fearless and strong. Old 


\section{AFRICAN HEROES AND HEROINES}

natives who had traveled with Livingstone always ended by saying, "Ngaka (the doctor, meaning Livingstone), Ah, he was not a man like any other; he was a god!" Coillard says of him, "Gathering up all the stories of this extraordinary man, I conclude that he was energetic, playful yet full of dignity, generous, upright, and sincere."

Coillard at last reached the people with whose future his name will be linked-the Barotse. They were delighted that he had brought his wife with him, and were more than pleased that she could speak their language, for the Barotse people, having been conquered by the Makololo-descendants of the Basutos - speak to-day the Basuto language.

But once more difficulties arose, and on October 19th, I878, Coillard wrote in his journal, "The King of Barotseland will not allow me to enter his country because it is unhealthy," the real reason being that the witch doctors were unable to make up their minds whether he should be allowed to come in. They had administered poison to chickens; some had died and some had not. The Juju's answer whether permission should be given for the white man to enter was doubtful.

Serpa Pinto, the famous African explorer, whose life Coillard saved, says of him in his book of travels, "At times M. Coillard produced the most extraordinary effect on me; there was something in him that surpassed my intelligence. One day he was relating one of the most agitating incidents of his journey and concluded, 'We were within an ace of destruction.' 
'But,' I replied, 'You had arms, an escort-ten devoted men resolute in your defence.' He shook his head and said, 'I could only have saved my life by shedding blood, and never would I kill a man to save my own life, or even lives dear to me.' These words revealed a human type quite new to me, and which I am incapable of understanding, though $I$ admire it with all my heart."

Coillard would never allow himself to be called brave or heroic. "I have always hated adventures," he once said: yet moral courage he had in the highest degree. Not a man on earth could intimidate him, and he would face any risks without appearing to notice them.

As some of the mission's officials expressed strong disapproval of his proposal to commence a mission among the Barotse, he temporarily gave up the idea and, by the way of the Transvaal, retraced his steps to Basutoland. On December 7th, I879, he left for his long-delayed furlough in Europe. He spent two years at home, finding great sympathy in England, Scotland, France and Switzerland.

Major Serpa Pinto often crossed his path while they were travelling at this time through Europe. Pinto professed a deep admiration for Coillard, which he wanted everybody else to share. One day Coillard was requested to attend the Portuguese embassy to receive the sovereign's thanks for saving the life of so valuable a subject. Himself a very small man, he had to wait a long time in a very large room. At length the door opened to admit the explorer and the ambassador. 


\section{AFRICAN HEROES AND HEROINES}

The latter was a colossal personage, sword-girt, star blazoned, and stiff with gold lace.

"M. Coillard, who saved my life on the Zambesi!" announced the Major in his most dramatic manner. The huge ambassador made one bound across the floor, seized him in his arms and exclaimed "Portugal embraces you!" Coillard, nearly suffocated, found it difficult to preserve the gravity suitable for such an honor.

What was Coillard's consternation when, during his furlough, as the result of ill-advised government proceedings in South Africa, a rebellion broke out among the Basutos! Many lives were lost on both sides. Coillard hastened to London to interview government officials and members of Parliament to try and save his African children from the trouble that was overtaking them. In August, I 882, he was back in Basutoland-his village a heap of ashes, the mission compound a waste, their property pillaged, the congregation scattered to the winds. Many of the leading Christians had been killed, or had taken to drink.

In September, four weeks after their arrival, General Gordon of Khartum was sent to solve the trouble. He spent the evening of September 2Ist, I882, with Coillard, and stayed till 9 o'clock. One of the native chiefs whom Gordon met, expressed himself to the effect- "It is the white people who try to force us to rebel." Gordon was in a fury; he would speak to no one belonging to the Government. "He is a very upright man and a thorough Christian," says Mme. Coillard of him. "So no wonder he cannot get on with 
people who scarcely ever speak the truth." Ten months later she wrote home, "I do not wonder that General Gordon fled in disgust; so would any truthful and right-minded man." As soon as General Gordon left, the war began again, and was waged for months.

On January 2nd, r884, the five thousand pounds needed for the expedition to Basutoland had been secured, and a start was made. Ten months after they left peace was restored in Basutoland, and since then the country has been administered as a Crown Colony on the lines laid down by General Gordon, though disregarded at the time. Basutoland is now the most prosperous, loyal, and orderly of the African protectorates.

With four native evangelists and their families, a young Swiss missionary named Jeanmairet, two artisans, and M. Coillard's niece, M. and Mme. Coillard travelled for eight months until they got to Barotseland-a tedious journey, happily free from adventure, though seventeen of their oxen died and six horses (four of them presents from the Basuto chiefs to Khama). On the way, at Pretoria, the first missionary meeting was held, at which the Vice-President of the Transvaal, General Joubert, took the chair.

When Coillard arrived at Mangwato (King Khama's place) letters reached him from Mr. Arnot of the Garenganze mission (who was then staying with Lewanika), to the effect that this chief had refused permission to the Jesuits to establish a mission among his people, but was asking for Coillard. They experi- 


\section{AFRICAN HEROES AND HEROINES}

enced during this time a combination of loneliness with never-aloneness.

Temporarily Lewanika was driven out of his country by certain revolutionists, but ten months later (in I 885) he returned. On September 24th, I885, the mission station at Sesheke was opened under Jeanmairet's charge. Two months later he married Coillard's niece. The very first night after they had arrived at Sesheke, some fugitive women who had belonged to the revolutionists, were massacred close to the camp to which these women had come for help; but, shortly after, the new station became neutral ground-"a city of refuge"-and chiefs of the two parties in the country frequently took shelter at the station for the night.

A permanent mission house near Lewanika's capital was built at Sefula, a hill about four hours' journey from the capital. Coillard had left his family behind at Sesheke on his first visit to Lewanika, after the building site for the new station was chosen. A Scotch carpenter, Mr. Waddell, and another helper, returned with Coillard to put up the first house at Sefula.

On February 28th, I 887 , Coillard writes, "Our Sundays are growing interesting. Yesterday we had a hundred and fifty auditors. The great attraction is our little harmonium. But how difficult it is in the open air to hold these restless spirits captive! It may be the wind, or the sun, or the rain. It may be a bird flying past, a fowl cackling, or dogs barking and fighting. They greet each other, too: they chat, they laugh, take snuff, and go. ... However, it some- 
times happens that these poor people do listen. Yesterday I was telling the story of the Deluge. They understood me; their attention was riveted. And when, after having spoken of that deluge of fire predicted by St. Peter, I appealed to my audience and cried, 'Whither will you flee then from the wrath of God?' 'To thee, O Moruti, our father,' replied several voices at once. 'And why should we flee,' asked an old man seriously, "we are not sorcerers?"

By January, I 888 , a year after the missionaries arrived at the capital, the days of anarchy were practically ended, but almost all who had had tradition, and experience, and authority of leadership had been exterminated; and only timeservers, and men without any sense of responsibility, and some very young people, remained. Famine threatened everybody, so a raid was planned and carried out, in which raid a neighboring tribe was despoiled of immense numbers of cattle, and troops of women and children. These were distributed as booty. The missionaries, too, had been robbed of all their cattle, one by one; everything that grew in their gardens had been stolen. Coillard advised Lewanika to encourage cattle raising, and not to kill the herds. This advice was acted upon, and ten years later traders came from many parts of South Africa to buy oxen from Lewanika. Coillard then taught the chief how to grow wheat. After attempts lasting over three years, he succeeded well, and the country now shows every evidence of becoming an important source of wheat. He also taught the people the use of bananas. Coillard sent for a plow and 


\section{O AFRICAN HEROES AND HEROINES}

tried to teach them the use of oxen for plowing, but in this he failed.

In 1890 Barotseland became a British protectorate, and eighteen months later Mme. Coillard died, the first white woman in this protectorate.

Coillard corresponded with Cecil Rhodes at the urgent request of Lewanika, and asked the former to send a representative of the Government to deal with Lewanika in the question of establishing a British protectorate over his country. Later, difficulties arose with Portugal claiming part of Lewanika's country. This trouble was submitted to the King of Italy, who acted as intermediary between Great Britain and Portugal.

In 1896 Coillard was home in Europe for his second furlough. He was welcomed in France with an extraordinary outburst of enthusiasm and affection. Toasts were drunk to his "heroic simplicity." One day when he was visiting some friends, his hostess came late to the supper table. She excused herself for being late. "I was putting my little boy to bed, and when he was saying his prayers, I bade him pray for M. Coillard. He asked, 'Why does every one make such a fuss (tant de cas) over M. Coillard?' So I began to tell him why, and he said-What do you suppose? 'I think we must all ask God not to let him grow too proud.'" Everybody laughed except the subject of this remark; he looked very grave. The next day in private the hope was expressed that he had not been annoyed by such an embarrassing speech. "Oh, no," Coillard replied. "It was God's message to me, and $\mathrm{He}$ sent 
it by the mouth of a child so that it should not wound me."

He frankly preferred English colonial rule to any other for the natives, but he admired it not unreservedly, because he thought justice had at times been sacrificed to party politics.

$\mathrm{He}$ was a great admirer of Mr. Hudson Taylor, in whose China Inland Mission he had often found much inspiration. There was an affinity between them. Each had been encouraged by the victorious faith of the other. One day, seeing Mr. Hudson Taylor (like himself a very small man) struggling with a very heavy overcoat, he came to the rescue, saying as he did so, "I am so glad to have an opportunity of helping you just for once."

"Dear Brother," was the reply, "you have helped me all your life."

Once when they were visiting the Guinness family at Cliff College, England, one of his Zambesi Christians whom he had with him, came to his room at night after all had gone to bed, sobbing violently. "O master!" he said, "I understand only now how much you have left in going away from these countries where every one is your friend and loves you, to our wild people in Central Africa, where there is so little love."

Two and a half years he spent in Europe. Though he did not plead directly for the Barotseland Mission, the income of the Paris Mission rose (thanks largely to his influence) from thirteen thousand to forty-nine thousand pounds in ten years. He never dealt in missionary pastry. He had no set addresses which he 


\section{AFRICAN HEROES AND HEROINES}

could suddenly produce. He carefully prepared himself for every occasion on which he was asked to speak in public.

The very first Sunday that Coillard preached in Paris, a young man passing the door and seeing the notice, strolled in to listen. Next morning he offered himself for the Barotse mission. He belonged to a leading Protestant family, and had just completed a brilliant university career.

In 1898 Coillard sailed once more for South Africa. $\mathrm{He}$ visited Basutoland again. In his journal he writes under February I2th, I 899, "From early morning; group after group arrived from all sides-all the chiefs of the country except one. The assembly met under my trees before the church, the same place where I had bidden them farewell fifteen years before. I spoke to them on my favorite theme-the Royalty of Jesus." Fifteen new members joined him at Bulawayo, arriving there by rail. He lunched at Government House, on the identical spot where, twenty-two years before, Lobengula had held him captive at his kraal. Coillard's party was the largest caravan that had thus far passed through Rhodesia to the Zambesi. This passage made the forest track into a road. An African proverb says, "Where the wagon wheel has passed the grass never grows again."

At Lewanika's court a Christian had been appointed to the office of prime minister. What a change in ten years!

Under January 6th, I900, Coillard writes in a private letter from Barotseland, "The King invited us 
to a great dinner. He presided at a splendid table with more calm and dignity than I credited him with. That meal I could not help comparing with the first dinner, where I found myself rather a cumbersome guest. The King, squatting on a mat, was tearing a duck with his teeth, and when he had satisfied himself passed me the rest, remarking that I must be hungry. Of course to look at him had quite satisfied me!"

In I 902 took place Lewanika's memorable visit to England to be present at King Edward's coronation. $\mathrm{He}$ returned on January ist, I903. Coillard had gathered together all the children from the five schools (about five hundred) to welcome Lewanika back. The following Sunday, Lewanika made a speech in church, and at the close of it said, "The gospel is everything. It is the Gospel which makes people intelligent, brings them success, and gives them security and happiness. Missionaries told me of this, but now I have seen it. Barotse, let us come out of our darkness, our ancient heathenism. Come and hear the teaching of our missionaries. Come on Sunday. Send your children to school-that we too may become a nation."

In 1904 the Ethiopian trouble was rampant in Barotseland. Coillard marked in his Bible, "I have labored in vain, and spend my strength for nought."

In May, I904, he was attacked with the dreaded hæmaturic fever, and died on the 27 th of the month. His work was done. He plowed and sowed, and others will reap the harvest.

On June the Ist, two days after the funeral, the 


\section{AFRICAN HEROES AND HEROINES}

railway reached the Victoria Falls. The pioneer days were over.

Coillard was almost seventy years old when he died. A marble cross erected by his colleagues marks the spot where he lies buried beside his wife under the great tree of Sefula, and on the cross are the words, "To live is Christ"- the motto of his life. 


\section{CHAPTER III (Continued)}

A Pioneer among the Bantus, George Grenfell 


\section{GEORGE GRENFELL}

I849 (August 2Ist) George Grenfell was born near Penzance, England.

I874 (November Ioth) Accepted by the Baptist Missionary Society.

I874 (December 19th) Landed in the Cameroons.

I875 Arrived in England on first furlough.

I 876 Second journey to the Cameroons.

1878 (January to March) First visit to Congo.

1878 (May to October) Second visit to Congo.

I880 (November) Visit to Fernando Po.

I880 (December) Returned to Congo mission.

I88I Second furlough from Africa.

1882 (December 9th) Left England for Congo.

I 887 (February to September) Third furlough.

I 890-I (December to November 3rd) Fourth furlough.

1 892-3 (May to June) Commissioner for King Leopold.

I900-I (May to September) Fifth furlough.

1906 (July Ist) Died at Basoko. 


\section{CHAPTER III (Continued)}

"SAY, Tom, cheer up, old man: we'll hear to-morrow or perhaps next week. They won't forget us, and if they try to, we'll send them another reminder."

"I know George, you're always optimistic. You're personified optimism! Do you really think we're good enough? I wonder sometimes whether we are really meant to go."

They were both meant to go and both of them went: and both died in foreign service-George Grenfell and Tom Comber-and George Grenfell stood out a heroic figure-the great missionary of the Congo region.

There are two ways of dealing with primitive races. The one is to appropriate them, their lands, their belongings, and all they have, to force them to work for you, and mentally or physically enslave them. Of this you read in your school histories. The other way is to convey to them the restraining and elevating influences of the religion that has made us what we are, and thus give them the foundation for the true civilization of the free. Grenfell chose to go to South Africa not to command and domineer over the natives, but to serve them and raise them out of savagery to the level and nobility of free Christians. To do this he was prepared to live among them, to heal their sick 


\section{AFRICAN HEROES AND HEROINES}

and teach them honesty. Should they suspect him and even kill him, he was prepared to die without any one avenging him. He faced the dangers of a deadly climate day after day for many years. This does not look as heroic as leading a forlorn hope in the battle, as saving the guns, or creeping up the hillside under a heavy rifle fire. But the brave man is he who faces his risks knowingly, and lasts out in long-continued dangers, including the attacks of savage men, wild beasts, and horrible epidemics. Indeed it is harder to face for thirty years disease and death under scorching heat, chilly cold, discomforts month after month, than, in a moment of enthusiasm, when the mind is worked up to the supreme sacrifice, to lay down one's life quickly and have done with it. In the life of George Grenfell we have exemplified in a supreme way the word "genius," which is interpreted-perspiration, patience and perseverance.

George Grenfell was born on August 2 Ist, I 849, at Trannack Mill, in a house situated on his grandfather's property about four miles from Penzance, near Land's End in Cornwall. He was educated in King Edward's School and grew up in the Midlands near Birmingham. At fifteen years of age he was apprenticed to a Birmingham hardware and machinery firm, and thus he became a practical mechanic. Later he studied in the Baptist College at Bristol. He was twenty-five years of age when his life's work began. In I 874 Alfred Saker, a missionary of the Baptist Society, at work in the Cameroons, was home on furlough. The accounts Saker gave of the work were such that Grenfell decided 
to follow him, and before the end of the year he found himself among the Dualas in the Cameroons. Two years of work there, then home to England to be married to a Miss Hawkes, but only for a year was she to be his companion-after twelve months she died. The loss of his wife affected him profoundly. He said to friends, "I have done a great wrong in taking my dear wife into this deadly climate of West Africa." He always felt strongly about missions employing white women in the fever forest belt. When, later, he married again, his second wife, a Mrs. Edgerly, was a West Indian and colored.

In 1878 , a few months after Grattan Guinness had started the Livingstone Inland Mission, Grenfell was sent to the Lower Congo, with the view of founding a chain of mission stations from the mouth of the river right across Africa to the Indian Ocean. Some difficulties with the natives caused him to return to the Cameroons, and he left the Mission for a short time; but two years after, he was back on the Lower Congo, and there established his first mission-stationMusuko.

Physically, Grenfell was below the average in height, though strong and robust. He was essentially a man of peace and won the confidence of the savages by his patience and tact, never responding by violence to insults. The Belgian geographer, A. G. Wauters, says of him that for twenty-five years Grenfell was a pioneer, with as much humanity as success. From I 894 he held the honorary position of British pro-consul on the Upper Congo. He was a Knight of two Bel- 


\section{AFRICAN HEROES AND HEROINES}

gian Orders, that of Leopold and of the Lion of Africa. He was created Commander of the Order of Christ by the King of Portugal. In I 886 he was awarded the Gold Medal of the Royal Geographical Society. In 1902 his magnificent cartography enabled the Royal Geographical Society of Great Britain to publish their great map of the Congo. He spoke French and Portuguese beside his mother-tongue, English, and did not a little linguistic work in the native tongues of the Congo.

Grenfell, like many other pioneer missionaries, made his time and place observations, his vocabularies, and anthropological notes, with the greatest care. He was fortunate in finding in Sir Harry Johnston a biographer who was willing to give honor to whom honor is due. Many a missionary hands his notes to explorers, or consuls, or captains of ships, in whose publications they appear, sometimes with an acknowledgment of their source and sometimes not.

Now for some of Grenfell's experiences on the Congo.

The Peace of the Congo was the first steamer launched on that great river-launched by Grenfell. Listen to a description of how he placed that steamer on the river. She was built on the Thames in England, taken to pieces and, in charge of an engineer, sent to the mouth of the Congo, and thence transported on men's heads to Stanley Pool. On the way the engineer died. Two other engineers were sent, but they died. Grenfell himself took matters in hand. The steamer had been cut into eight hundred pieces and all were carried on 
men's heads, for there were no railways or roads. Through thick grass higher than men's heads, across streams and frail bridges of creeper vines, over ravines with tackle and pullies, the packages were hauled, dragged or carried. At night driver-ants sometimes took possession of his tent and drove Grenfell from it until it pleased the ants to go. One night in the dark he reached for matches and, striking a light, saw a four-foot snake between the match box and the candle. On another day a savage aimed his gun at Grenfell leaving only about a foot between the muzzle of the gun and his face. When at last the boat was built, hippos disliked it. One big fellow left the mark of his teeth in the steel plates. Grenfell said the boat had been "prayed together." But do not imagine that this means the pieces leapt together. No such thing! Every plate had to be fitted, every rivet driven, every detail thought out and worked out, with weary brain and wet perspiring body.

When the steamer first begun to move the natives shouted, "She lives! Master, she lives! The Peace lives!" The Peace became known on the river as "God's Boat," the boat which offered violence to none. Sometimes the white man was welcomed: often he was suspected and had to be on guard. The natives threw spears and shot poisoned arrows at the steamer. This kind of attack had been provided against. Defense, not defiance, was carried. Her deck was screened in with wire netting, through which the spears and arrows could not penetrate, and the Peace sailed on. One 


\section{AFRICAN HEROES AND HEROINES}

day on the Mobangi the steamer was attacked by about fifty canoes, many of them large ones. Spears and arrows, sticks and stones, were thrown at the steamer. She sailed on; but later, coming down the river, Grenfell landed at this very place, made friends with the natives, and bought spears, knives and other curios from those who had attacked him. Sometimes, at the beginning, non-resistance was deemed by the inhabitants to be cowardice, but later the people learned to know that the white man on board that boat was one of the bravest of the brave, although his fighting was not done with gun and rifle.

It was late afternoon, and the dry season of 1884 , when on his steamer Peace lying at the mouth of the Lomami, he noticed the eastern horizon reddened by the reflections of fires. He took these fires to be those of salt-makers, for the natives burn the grass on the river banks when it is dry enough, to make salt out of the ash. Later he noticed high flames shoot up and then boats came down the river, dug-out canoes crowded with fugitives, natives flying from the Arab slave-raiders. Wreckage also began to float down by the side of the steamer. From midnight until three o'clock in the morning "an unceasing and continuous stream swept by, of hut roofs, beds, stools, calabashes, fishing-nets, ropes, and all the gear that had been thrown into the river, partly from the town and partly from the canoes of those runaways who found themselves hard pressed, or from those captured by the Arabs, who would not be bothered by such plunder." With daylight Grenfell ordered the anchor to be taken 
up, and in a little more than an hour reached the smoking ruins of Yambuli, formerly a town of four thousand people. From another village a little further up the stream, natives called out as the steamer passed, "We have nothing, nothing! Our houses are burned, our plantations destroyed, and our women and children are gone!"

When the natives, who had never seen a white man, were first visited by Grenfell they called him "Bidimo" (Spirit). He was indeed the good spirit who, before his earthly career was finished, counted his friends among the Pigmies of the great Ituri Forest, among the Ballolo of the Horseshoe Bend of the Congo, and among the cannibals who had their teeth filed (the sign of cannibalism). Many of them discontinued this custom after he had been among them for a while.

One day a half starved native came to Grenfell and exclaimed, "White man! White man! I am the only one who escaped. My two companions and myself were left by Bula Matari (the Rock-Breaker-the name by which H. M. Stanley was known) among the Basoko at the mouth of the Aruwimi. They ate my two companions, and they only let me escape because I was too thin."

On the I $5^{\text {th }}$ day of September, I 885 , when travelling in the Peace up the Juapa River, Grenfell came upon a group of cannibals just about to kill a man and eat him. He tried to buy the man from them for money but they would not sell. In another place they offered him a fine-looking woman as a wife, in exchange for a plump boatman whom they wanted to eat. Yet 


\section{AFRICAN HEROES AND HEROINES}

there was plenty of cassava and sugar cane and other food to be had.

But such incidents were rare. The usual thing for the natives to do was loudly to deny that they were cannibals.

"Chief! I have heard that you like human flesh. Tell me what it tastes like," asks Grenfell.

"Human flesh!" replies the chief in a tone of horror. "White Father, we do not eat that. If you travel on to-morrow you will get to a tribe. They are cannibals."

Grenfell journeyed on and coming to the new tribe on the next day called upon the chief.

"Chief, I have heard that human flesh is good to eat. Tell me what does it taste like?"

"White Spirit, you are misinformed. We do not eat human beings. The people you were amongst yesterday, they are animals and eat men."

No other European had been among them but they somehow realized that cannibalism was inhuman, thus enabling Grenfell the more freely to speak to them of the great truths he was there to make known and establish.

The coinage used on the Congo when he arrived consisted of brass rods which the natives called "lunkundu." The Hamitic people south of the Great Desert freely use silver as coinage and ornament. South of them the Masai and some of the Congo tribes use brass, and to the south of them again, and among some tribes near the coast, iron is used for bracelets and anklets, and also as coinage; while the wild people 
of the Bukuru Plateau in Northern Nigeria use soft black tin.

The greatest slave-raider of his day, Tipu Tip, was visited by Grenfell on Christmas Eve, I 884, at Stanley Falls. On that journey our missionary had not only to deal with cannibals, but with cannibals exasperated by Moslem slave-raiders; and when, later on, the Belgian government added its opposition, it was more than Grenfell could bear.

The two steamers which figure much in the exploration of the Congo were the Peace, given by Robert Arthington of Leeds, and put together by Grenfell, and the Henry Reed, which was presented to the Livingstone Inland Mission in 1883 by Mr. Henry Reed of Tasmania. The Henry Reed was used by the early explorers, Uchtritz, Wissman and François, while the Peace was appropriated by Stanley, who in I 887 tried to solve the Congo difficulty by appointing the slaveraider, Tipu Tip, governor at Stanley Falls. Stanley peremptorily borrowed the Peace without permission, and thus for the time put an end to Grenfell's explorations. In I 889 the Arab's attitude towards the Congo State became insolent. Tipu Tip threatened to come with a fleet of canoes and take Leopoldville, but in 1890 , for health reasons, he retired to Zanzibar. During the same year the Peace was used by the Government to take part in the war against the Arabs. The Mission resented being mixed up in a war, just or unjust. A protest was made in Brussels. Grenfell himself made this protest; he was ill with fever and much upset, and the Belgian Government promised 


\section{AFRICAN HEROES AND HEROINES}

that no such incident should be allowed to occur again. The special danger was that the mission stations were left without supplies and the lives of the missionaries in jeopardy, as the Peace was not doing her duty. Consequently in I89 I a new and larger steamer, the Goodwill, was built on the Thames and taken out by Grenfell. She was launched in December, I893, on the Upper Congo.

The same Congo State he helped so much, so freely, and encouragingly, which, in the early eighties and nineties, he spoke of as "an ideal government, an international Utopia" - that same Congo Government, lacking in strength to put down atrocities, was yet strong enough to prevent Grenfell from carrying through his and Robert Arthington's plans-a chain of mission stations from the West Coast of Africa to the East Coast. Sir H. Johnston says of George Grenfell, "He was a rare exemplification of Christian charity, eager to applaud good work in others, looking everywhere for the good motive, chary of blaming or condemning without conclusive proof, absolutely incorruptible, however, no fool to be easily gammoned into incipient acquiescence with wrong-doing, whether it be by steamer boy, mission scholar, state official or a native chief." In a letter written shortly before his death, to a Belgian official, Greenfell says, "I am désorienté." $\mathrm{He}$ did not know in what direction to turn for putting straight the Congo trouble, dealing with the ravages of the sleeping sickness, or the mistaken policy of King Leopold who was getting the Central Congo region into a deplorable state. He had 
known personally every Belgian pioneer of any standing, and had formed a high opinion of most of them, and therefore was in trouble, the greater because of his knowledge. In one of his last statements about the Congo he says, "Having lived more than half my life in Africa and being circumstanced as I am, the interests of no country count with me for more than those of the country in which I have expended so much of my life and energy. The Congo State had no more enthusiastic partisan than myself, and now for me to find things going wrong is a great and bitter disappointment."

"A roaring, epic, rag-time tune

From the mouth of the Congo

To the Mountains of the Moon.

Death is an Elephant,

Torch-eyed and horrible,

Foam-flanked and terrible.

Boom, steal the pigmies,

Boom, kill the Arabs,

Воoм, kill the white men,

Hoo, Hoo, Hoo.

Listen to the yell of Leopold's ghost

Burning in Hell for his hand-maimed host.

Hear how the demons chuckle and yell

Cutting his hands off, down in Hell.

Listen to the creepy proclamation,

Blown through the lairs of the forest-nation,

Blown past the white-ants' hill of clay,

Blown past the marsh where the butterflies play:-

'Be careful what you do, 


\section{AFRICAN HEROES AND HEROINES}

Or Mumbo-Jumbo, God of the Congo,

And all the other

Gods of the Congo,

Mumbo-Jumbo will hoo-doo you.' .

"Then along that river, a thousand miles

The vine-snared trees fell down in files.

Pioneer angels cleared the way

For a Congo paradise, for babes at play,

For sacred capital, for temples clean,

Gone were the skull-faced witch-men lean.

There, where the wild ghost-gods had wailed

A million boats of the angels sailed

With oars of silver, and prows of blue

And silken pennants that the sun shone through.

'Twas a land transfigured, 'twas a new creation.

$\mathrm{Oh}$, a singing wind swept the negro nation

And on through the backwoods clearing flew:-

'Mumbo-Jumbo is dead in the jungle.

Never again will he hoo-doo you.

Never again will he hoo-doo you.' "

From The Congo, by Vachel Lindsay.

Years of labors, and fevers, and hardships at last told their tale. "A man at my time of life in Central Africa is an old man," he writes. He had not wasted his years. On the 28th of April, I906, he fell ill at Yalemba. "I lie down with fever," his diary tells us. For weeks he got up and lay down, never free from fever, yet always directing and encouraging his native attendants at their work. It became too much. The natives were at their wits' end. On the rgth of June they wrote the following letter for help. 
"My dear Sirs,

Millman and Kempton and Smith. We are very sorry because our Master is very sick. So now we beging you one of you let him come to help Mr. Grenfell please. We think now is near to die, but we don't know how to do with him.

\section{Yours,}

\section{Disasi Makulo and Mascoo Luvusu."}

Grenfell became worse, and gave his servants leave to take him to Basoko in the Peace. At Basoko there was a state doctor. It was all too late. In the early hours of Sunday, the Ist of July, I906, George Grenfell had gone home, and Baluti, one of his faithful blacks, wrote: "The death of Tata (father) is finished!" 



\section{CHAPTER IV}

The Sower of East Africa, and KRAPF's Memories of Abyssinia 


\section{JOHANN LUDWIG KRAPF}

I8Io (January IIth) Born at Derendingen, Würtemberg. 1827 Enters Basle Mission School.

I 829 (September) Passed his matriculation examination.

1834 Finished his theological studies at Tübingen.

1837 (February 6th) Left Basle for East Africa.

1837 (December) Reached Massowa.

I842 Furlough in Egypt.

I843 Back in Massowa.

I844 (January 7th) In Zanzibar.

I 846 His wife dies and his child.

I848-9 In the Interior of East Africa.

1850 (April) His first furlough in Europe.

I85I Returned to East Africa.

1851-2 Travels in the Interior.

1853 Second furlough.

I854 In Palestine meets Bishop Gobat.

1855 In Switzerland.

I 868 British expedition to Abyssinia, meets Stanley.

188I (November 26th) Krapf died on his knees, not far from where he was born. 


\section{CHAPTER IV}

Three years before David Livingstone was born, another African path-finder, Ludwig Krapf, came into this world-on January IIth, I 8 ro. He was born in the little village of Derendingen in the south of Germany. His people were farmers. He went first to the village school, and when thirteen years of age was sent to a grammar school in Tübingen, where he worked at Latin and Greek. He was much interested in maps and geography. Bruce's "Journeys in Abyssinia" he devoured when still a boy. At the age of fourteen he said to his parents, "I am going to become a traveler and see other countries." He wanted to go to sea, but the expenses connected with the naval training were such that the father was unable to do as his son desired. After his final examinations at the grammar school, the question was raised whether he should study medicine or law. Theology was more to his taste, but he was afraid of Hebrew. The Head Master of the school one day read to his boys a paper on foreign missions, and this so impressed young Krapf that he decided to become a foreign missionary. Then he asked himself the question, "How can I teach others when I know so little of my Savior myself ?" Thereupon he decided to begin an intensive study of the Bible.

At seventeen he went to the mission-house in Basle, Switzerland, to be trained as a missionary. The rules 


\section{I04 AFRICAN HEROES AND HEROINES}

of the mission school were severe, and in some ways not altogether wise. The reading of the Mystics was forbidden, and as a natural consequence the enterprising youth became very much interested in the Mystics, and promptly read Mme. Guyon and Jacob Boehme. The Basle mission school gave him his congé, and back to Tübingen he went to study theology, finishing there in 1834 , in which year he took his degree.

Two years later, in 1836 , when Ludwig Krapf was twenty-six years of age, the secretary of the Church Missionary Society of England came to the south of Germany and to Basle to look for recruits for his society, for in the early days the Basle mission-school supplied a number of missionaries to that great English Church mission. Among them were men like Pfaender (whose polemic writings are to this day the ne plus ultra tools of all missionaries going to the Moslems), Schoen and Klein (the former remembered for his linguistic work in West Equatorial Africa, and the latter a pioneer missionary in North Africa). But the greatest of them in those days was Dr. Koelle, who wrote the "Polyglotta Africana"-a parallel vocabulary of three hundred words in a hundred different African languages.

Krapf met the secretary of the Church Missionary Society, and just then the news came that a former student of Basle who had been appointed by the C.M.S. to go to Abyssinia, had died, and Krapf was asked if he would go. He agreed to this, and on February 6th, I 837 , he travelled by way of Marseilles, Malta, Alexandria, Cairo and Suez to Massowa. 
After some years of work in Abyssinia he came back to Egypt and was married in Alexandria on the 22nd of September, I84I. Two years of furlough followed, and on the I I th of November, I 843 , he was back in Massowa, having been asked to go to the East Coast of Africa to become the pioneer missionary there. After six weeks' journeying he arrived at a place called Takaungu, north of Mombassa.

The British consul at Zanzibar welcomed Krapf and his wife and secured for them a letter of introduction to the coast chiefs from the Sultan of Zanzibar. This letter sounds very quaint. Here is a translation of it.

"In the name of God, the most merciful and compassionate, this letter comes from Said, the Sultan. To all our friends, governors, and subjects, greeting.

"This letter is written for a Dr. Krapf, who is a good man, and desires to convert the world to God. Treat him kindly: serve him all you can, and everywhere.

"This is written by order of your Master."

Krapf had been about six months in East Africa when he commenced the translation of the Bible into the widely-spoken East African trade language, Suahili, and for two years he did little else but translation work.

At the end of June, I844, a fellow helper was sent out to him-a man by the name of Rebman-when, a week later, on the $5^{\text {th }}$ of July, his wife fell ill. That year the rains had been exceptionally heavy. 


\section{Io6 AFRICAN HEROES AND HEROINES}

The severe illness had a depressing effect upon her mind, and she pleaded with her husband for assurances that she really and truly was a Christian. She prayed, "O my Savior, I am unworthy to have any place in Thy Paradise, but have pity on me, and give me a small corner at the edge of Thy glory, that I may be with Thee." Her husband in his sorrow assured her, "Christ is as surely thine, as you are mine and I am thine. Do not give way to temptations of the evil one. It is time to flee to the Lamb of God that taketh away the sins of the world." With such and other words she was greatly strengthened. With tears in her eyes she thanked her husband for his words of comfort, and God for all that He had sent her during her life. Then she prayed for East Africa, for the Sultan of Zanzibar, and for all the people there. Her husband who had watched with her from midnight till dawn begged her to rest. "No," she said, "there is plenty of time for rest. Now it is time for work." She called the servants, told them that she was dying, and that in the face of death she had to say to them that if they trusted in Mahomet they trusted in a delusion. "He cannot help you in the hour of death, but Christ can and does." And turning to her husband she said, "My dear one, do not forget to speak to every one whom you meet about the great truths. Even if your words have no effect at the moment, they will come to their remembrance in the hour of of death. Do not sorrow because of me, but 'work while it is day.' " She asked that nothing of her letters and diaries should be published. There was too 
much of self in them. Then she asked her husband not to praise her in his letters home because she was not worthy of praise, but to say that she-a poor, miserable sinner-had received forgiveness through the unmerited grace of Jesus Christ.

Krapf, who himself had fever, felt the need of rest, but she could not rest-praying and rejoicing until the afternoon. Then her fever rose to such a point that her mind wandered. On the IIth of July she was somewhat better. They wept and prayed together. On the 12 th the fever rose again. Krapf had a very severe attack, and only now and then could he drag himself to her bedside. On the morning of the I $3^{\text {th }}$ she breathed her last. Krapf himself could hardly get up from his bed. There she lay growing stranger. to him at every moment, her glassy eyes and chilling body, like a garment left behind, told him only too well that she had gone. The future lay dark before him. How gladly he would have followed her! Her burial took place the next day. Krapf managed to struggle to the grave-side. On his return he found his little child lay ill too. She died the same day, and on the $5^{\text {th }}$ he had to take his baby and bury it by the side of her mother.

To the secretary of the Church Missionary Society he wrote-

"Tell the Committee that on the East Coast of Africa there is a lonely grave in which rests the body of a member of your society. This is a sign to you that you have begun the war for this part 


\section{I08 AFRICAN HEROES AND HEROINES}

of the world, and as the victory of the Church is won over the graves of many of her members you may be assured that the hour is near in which you will be called upon for greater sacrifices for Africa: Do not count the losses in this glorious battle of those who fall and suffer, but press onwards until East and West Africa are joined through the bonds of Jesus Christ."

The loss of Krapf's wife was for him a heartrending experience but of the utmost importance for his future life, which now became fully consecrated to God's service. The grave-stone of his wife became one of the great corner-stones of the temple of God in Africa.

In I 848 and I 849 Krapf was on his third journey to Africa. It was at this time that he first travelled into the interior, and saw the snow-capped mountains in the Tropics-Kilimanjaro and Kenia. Mountains always have a great attraction for people who have been brought up among them, and Krapf's stories about the Switzerland of Africa and the snowy peaks of the south created a great sensation when he was home in Switzerland in I 850 . Not only was the Basle Mission interested, but a branch school of that society (which had been established at St. Chrischona, not far from Basle, as a training institute for home evangelists) caught the enthusiasm, and young men began to volunteer from that institution to go out as missionaries to Africa.

In I $85 \mathrm{I}$ and $\mathrm{I} 852 \mathrm{Krapf}$ was on his fourth journey, 
and extended his travels to what is now known as British East Africa and Gallaland.

He tells in his book "Travels and Missionary Labours in East Africa" (page 70) some of his experiences in the interior, "I was once in great danger of being sacrificed because it had not rained for a long time, and the absence of rain was ascribed to me, as if I could have hindered it from falling, and again, with no less haste, I was almost deified when, after a long drought, there was a sudden fall of rain. It was ascribed to my walking on the soil."

When in England in 1854 , he brought to the Committee of the Church Missionary Society glowing accounts of the lands he had travelled through, telling of the need of missionary work there and their possibilities, and declaring that, while the East Coast was unhealthy, the plateau country in the hinterland had a delightful climate, and the tribes were friendly. He urged that the work of the mission should be extended further afield.

In that same year Krapf visited Jerusalem to confer with his friend, Gobat, the first Anglican Bishop there, whose daughter (Mrs. Rappard) was the wife of the Head of the St. Chrischona Institute. They got out their maps of Africa,-(What poor and faulty maps those were sixty years ago!) - and when Krapf told of his experiences among the Abyssinians of the ancient Christian Church there, how sadly she stood in need of being modernized and refreshed by intercourse with other Christian people and newer branches of the Christian Church, Gobat said, "Why not link up Jeru- 


\section{IIO AFRICAN HEROES AND HEROINES}

salem with Gondar" (the capital of Abyssinia) "and build a road of mission stations named after the Apostles?" So it was planned, and so it was done,-and thus began the "Apostle Street" to Abyssinia. Listen to Krapf's own words about this:-

"I have been appointed the secretary of a special committee connected with the missionary institution at Chrischona, for the purpose of locating twelve mission stations along the banks of the Nile, from Alexandria to Gondar, the capital of Abyssinia, whence other stations will be established towards the South-East and West of Africa, as it shall please Providence to show the way and point out the requisite men. This line of twelve stations will be termed 'The Apostle Street,' as each station will be fifty leagues distant from each other, and will be called by the name of an Apostle. For instance, the station at Alexandria will be named after St. Matthew, the station at Cairo St. Mark, at Assuan St. Luke."

From St. Chrischona numbers of men were sent, and shortly some eight or ten stations were established-at Alexandria, Cairo, Assiut and Luxor, at Berber and Khartum, and at Beni Shongul, close to the borders of the Abyssinian mountains.

A new companion had joined Krapf in his journeys, Martin Flad from St. Chrischona. When journeying in the desert that lies between the Nile and Abyssinia, under the hot tropical sun, mounted on their camels with their Ababde Arabs singing by their side, Flad would call out from time to time, "Say, Krapf, see 
yonder that convenient bush!" They would slip down from their camels' backs, and while the caravan journeyed onwards would kneel and pour out their hearts in prayer to God that the good news of the Savior might be carried before long to the many peoples in the heart of Africa who had never heard of Him. It was very touching to hear of these doings of the early "Lightbearers" from Flad's son, who had taken the stories from his father's lips, and gave them at the first Sudan Mission meeting held at the Keswick Convention in England in 1903.

In Krapf's writings on Abysinia the following notes are among the most interesting.

"Jan hoi! Jan hoi! (O King! O King!) is the call with which the natives of Abyssinia approach their ruler. It was this title (Jan hoi) which in the I $5^{\text {th }}$ Century, when the Portuguese first came to Western Africa, led to the report of the great king-Prester John (Jan) -ruling in East Africa."

The quaint ideas of the Abyssinian priests and their interpretations of Scripture are exemplified in these quotations.

"Alaca Wolda Hann gave me some proofs of their skill in explaining scripture. 'The foxes have holes and the birds of the air have nests' (Matt. viii. 20) he explained. 'Those foxes are kings and governors who seek earthly things, but the birds are the priests and bishops who fly to heaven in their prayers and holy functions!'

"Furthermore (Matthew v. 29) 'If thy right eye,' 


\section{2 AFRICAN HEROES AND HEROINES}

etc. Of this he said, 'The eye is the wife, the hand the servant and the right eye the child.' When I told him the way in which we explained this passage he replied, 'That is one sense. We are fond of many senses of Scripture.' 'I then showed him the foolish and bad consequences of their explaining the Word of God, and that God would become displeased with them if we substituted two or more senses, just as the King of Shoa would become angry if his people were to give some other meaning to his orders.

"No Christian people upon earth are so rigid in their fastings as the Abyssinians. They fast in all nine months out of twelve-every Friday and Wednesday throughout the year, then again forty days before Easter, twenty-five days after Trinity, fourteen days in August, twenty-five before Advent, and on other occasions.

"Many of them believe that the Virgin Mary died for the sins of the world, and saved 144,000 souls. From the Abyssinian point of view the means to expiate sins are alms-giving, fasting, monastic vows, reading sermons, etc. They are extreme monotheists, for they admit only one nature and one will in Christ."

"A great discussion has been going on among the church leaders in that country concerning the threefold birth of the Son of God:-

(Ist Birth) Begotten of the Father before all the Worlds, 
(2nd Birth) Became man in time,
(3rd Birth) Was baptised in Jordan."

The journey in I 857 was the fifth time that our hero had visited East Central Africa: he was there twice more, from I 86 I to I 865 , and then from I 866 to I868. He was in Africa seven separate times, and on the last he journeyed with the British Expedition from Suakim to liberate the missionaries then imprisoned by Theodorus, the Menelik of Abyssinia. It was in this year that Stanley gained his first experiences in Africa, and no doubt Krapf's influence had its effect on Stanley, for both went up together to Kassala. The great change in Stanley's life took place through Livingstone, but in Krapf he saw the first exponent of the romance of missionary work in the Dark Continent.

A military expedition to save Christian missionaries has never yet done any good. It may save the lives of those devoted men, but it closes the door to the hearts of the people. As a result of the expedition the missionaries were withdrawn: Moslem fanaticism undermined the work in Egypt, and thus, with the objective gone in Abyssinia, one after another of the Nile stations was abandoned. The plan was artificial. An atlas and a map are not sufficient guides for spiritual work, just as with all the riches in the world no spiritual experiences can be bought. Once again the ancient Land of Prester John was closed to foreign missions; and with the exception of a small and halting work done by the Swedes along the borders of 


\section{4 AFRICAN HEROES AND HEROINES}

that land, no Christian mission work is carried on today in Abyssinia.

The fruit of Krapf's labors is, first and foremost, linguistic - the translation of the Scriptures into Suahili, and the translation of THE BooK into Galla by his friends; and, secondly, his work as a geographer,-an explorer,-which drew the attention of many and led to the expeditions of Speke and Grant, of Sir Samuel Baker, of Van de Deken and of Mme. Tinney to Central Africa.

Sir Harry Johnston says of Krapf and Rebman-

"They had gathered up the reports of Lake $\mathrm{Ny}$ assa, Tanganyika, and the Victoria Nyanza, and had imagined these separate sheets of water to be only parts of a huge slug-shaped lake as big as the Caspian Sea. These stories they illustrated by a map (Erhardt and Rebman) published in I 855. Their stories of snow mountains in equatorial Africa only drew down on them for the most part the ridicule of English geographers, among whom was a wearisome person, Mr. Desborough Cooley, who published fine-spun theories based on a fantastic interpretation of African etymology; but their stories were believed in France, and they were awarded a medal by the Paris Geographical Society. They also impressed an American poet, Bayard Taylor, who in 1855 wrote some stirring lines on Kilimanjaro:

'Remote, inaccessible, silent, and lone-

Who, from the heart of the tropical fervors

Liftest to heaven thine alien snows.' 
These stories from the missionaries revived the interest in Ptolemy's geography. The Nile lakes were once more believed in, especially as the discovery of Kenia and Kilimanjaro appeared to confirm the stories of the Mountains of the Moon. This idea indeed was additionally favored by the fact that the missionaries often referred to their hypothetical lake as the Sea of Unyamwezi, which name they rightly explained as meaning (we know not why) the 'Land of the Moon.'"

The influence which the lives of the great African pioneers have had upon other men, interesting them in the work they themselves tried to do, and which they frequently failed to carry through, has been greater in many cases than the work the path-finders did themselves.

Krapf died on November 26th, I89 I, kneeling by his bedside, in his home in a little village not far from where he was born.

When, in 1900 , Dr. Grattan Guinness, a missionary enthusiast, and the writer, were staying at St. Chrischona, having just returned from a visit to Nubia, and had told the young men at that training college that the doors to the Upper Nile and to East Africa, that were closed to their fathers, were now open, it was inspiring to see the response made by those students. Fifty out of the fifty-five leapt to their feet, expressing their desire to see the dreams of Krapf and Bishop Gobat now come true. 
CHAPTER IV (Continued)

A Woman and a Missionary-Mary Slessor 


\section{MARY MITCHELL SLESSOR}

I 848 (December 2nd) Born at Gilcomston, Scotland.

1875 (May) Offered her services for foreign missionary work of her church.

I876 (August 5th) Sailed for West Africa.

I883 (April) Ordered home on furlough.

I 885 Returned to the field.

I 888-1902 At Okoyong.

1902-1910 On the Enyong Creek.

1915 Died at Itu. 


\section{CHAPTER IV (Continued)}

"Have you seen Mary Slessor? She is the most wonderful woman in West Africa," came from the lips of Sir William Wallace, the Deputy Governor of Northern Nigeria, when the speaker and the writer sat, a dozen years ago, on the deck of the Corona, the Governor's yacht, as she slowly forced her way up the deep swirling waters of the Niger, at the end of the rainy season.

"Have you seen Mary Slessor? She is worth seeing," said one of the heads of foreign missionary enterprise to the writer when journeying along the west coast of Africa nine years ago.

"You ought to see Mary Slessor. She is a wonder," said a resident from Northern Nigeria, not far from Lake Chad.

Who was Mary Slessor? She was the woman Livingstone among the missionaries.

"Stop! Do you hear me! Stop!" the white woman called as she ran out of the bush path into the village field, where two tribes were about to settle their differences of opinion by force of arms.

"You dare not shoot while I am talking to you!" She was a weak woman, small of stature, telling men heated by lust of battle to stop fighting. She was only a woman, but what a woman! All the tribes far and near had learned to respect her. 


\section{I2O AFRICAN HEROES AND HEROINES}

"Come here, you!" to a man who, with his gun up, was about to fire. "Give me that gun, and go and find your chief and bring him here!" Then, telling her followers to clear the long grass away and put up her chair, she marched across to where the enemy was lined up behind the mud walls of the village, and, calling for the chief, she insisted that he come immediately, as she wished to speak to him.

Reluctantly the chief appeared at the stockaded gate. Taking hold of his arm she marched him back to her chair, which was placed under a shady tree in a clearing which her followers were busy in enlarging. A couple of antelope skins used by two of her servants as sleeping mats were stretched on either side of her chair. She motioned to the chief whom she had brought along from the village, to sit down on her left, when from the bushes on the right appeared the other chief followed by a crowd of his armed men, wildly gesticulating. Mary Slessor had sat down in the meantime, but she got up again and told the newly arrived leader of the warriors to send his men back into the woods. She wanted him alone. Was he afraid of her that he brought so many men? Reluctantly the tribesmen withdrew, and, scowling and growling, the newly arrived leader sat down on a mat at her right. It took her just ten minutes to settle the palaver, to turn two enemies into friends, to send them back to their people and to their work on the farms. One is tempted to say "they lived happy ever after," but that would hardly be true, for as soon as Mary Slessor's influence had faded, old troubles would begin again. 
Though Mary Slessor had no children of her own, she was called "Mother" by multitudes. She was a woman of great common-sense and fearlessness. At the very beginning of her missionary service she had considerable difficulty with punctuality. It is said of her that when she had no alarm clock, or if she had one that had gone wrong, she would tie a rooster to her camp cot, that he might wake her with his crowing at daybreak. Mary Slessor was a woman who could get on with everybody. She had no enemies and yet withal tremendous force of character. The natives trusted her absolutely. From long distances they came to bring to her their troubles, and unfailingly she straightened them out for them. When there were difficulties which the child-minds of the natives were unable to solve, they invariably turned to the "White Mother."

It was a warm spring evening in 1893 . The blue smoke rose from the cook-fires in the compounds of Okoyong. The dust haze of fine sand particles from the great Sahara that had hung over the forest all day had been driven away by a gentle south breeze. The palm-fringed forest awoke to its night life, when, through the bush path, moist and mossy, under majestic panoplies of cotton trees, a string of carriers struggled onward towards the clearing, singing quaint songs responsively in honor of the mistress who was coming to call upon a sister of her tribe, hidden for eighteen years in the jungles of the cross rivers. Weirdly their chant preceded their arrival, as Ma Akambo, barefooted, with a baby on her back and a bunch of bairns, 


\section{I2 AFRICAN HEROES AND HEROINES}

black as the midnight, around her feet, was doing chores and cleaning up before their evening prayers.

Mary Slessor straightened herself and listened, as through banana bushes, past yon native hut, the strange Safari (caravan) hove into sight. Another Mary, daughter of Charles Kingsley (Kingsley of "Westward Ho!" and of "Hypatia"), had come from far to meet our strange white queen of wild Okoyong. As Stanley once met Livingstone and with simple words, so often paraphrased, saluted the explorer, "Dr. Livingstone, I presume," so Mary Kingsley said to Mary Slessor, "I take it, you are Ma Akambo," while Mary Slessor answered, "My name is Mary, and I bid you welcome."

A greater contrast than we see in these two women could hardly be imagined,- - one barefooted, shorthaired and rough-handed, clad in poorest garments, serviceable though and neat, the daughter of a drunkard, but now an honored queen of multitudes of blackskinned savages, - the other, cultured, the daughter of a Christian gentleman of highest standing, her intellectuality far beyond that of the vast majority, and yet withal life's object for her was naught but globetrotting. The daughter of a Christian, yet professing no Christian principles, but "les extrèmes se touchent," and in the "Bang-bang" wilds of Central Africa strong cords of sympathy, of fellow feeling, yea of love, were knotted to last as long as life should last.

"Come in," said insignificant Queen Mary to her stately visitor, "Come in, and receive a Scottish lassie's welcome." They shared their evening meal, then by 
the fire they sat, while out of the night and gloom gleamed the white eyeballs of the children of the forest. For hours they sat and talked of life and higher life, life's meaning and life's object, of exploration, of palm oil ruffians (for by this name went nearly all the traders of the coast), of native superstitions, witchcraft, demon worship, of native women's degradation, and of the murder of all infant twins.

It was Mary Kingsley who was keen on folk-lore and who thought much of the poor barbarians' faith in the wily spirits of the gloomy forests, and felt that the work of missionaries might be the doom of many an interesting custom, while Mary Slessor, seeing beneath the surface, was far more interested in the work of saving babies' lives, relieving sorrow, hunting for opportunities to spread the knowledge of the Prince of Peace throughout the blood-drenched villages and hamlets of the natives.

"Had you been here," said Ma, "during the first years I lived at Okoyong, you would feel differently about what seem to you the beauties of native life, for sudden death and sicknesses of chiefs meant always human sacrifices in this land when I arrived. One day I was called into a village eight hours from Ekenge, to save if possible the life of the chief, who then was dying. The intervening villages were hostile, no natives dared to follow when I left to save, if it might be, the lives of many slaves and women who would be slaughtered if the king should die, in order that beyond the grave he might have servants in the future life. After exciting hours, and a march through 


\section{24 AFRICAN HEROES AND HEROINES}

drenching rain, I reached my destination and was welcomed by the grim expectant faces of an armed crowd that was ready to begin the slaughter as soon as it should hear from the king's compound the death wail. I felt as if I'd walked into a den of wild beasts. With some medicine which I was able to procure, with not a little trouble, from another station (Ikorofiong) where a married missionary couple were working, the ebbing life was saved, and with it the lives of many of the forest children."

"What do you know of undesirable women being sold to Inokong to serve as food at the high feasts of this section of the Aros? All twins whom God sends to the mothers of this country are killed and many of the mothers too. One day Etim, the eldest son of our chief Edem, had been hurt by a tree falling on his back and he had died. According to the custom, men and women, yea and little children, from the nearest village were condemned to death, it being held that they, by witchcraft, had caused Etim's death."

"I could speak to you for half the night were I to tell of all the trouble I had to save the lives of those poor wretches of the village. It cost me silks and satins to save some; for others I cajoled the chief so that he set them free, and, for the last, long prayers and threats were needed, and to this day it is a wonder to me that not one was lost: it was God's gracious hand that gave to me the lives of all those villagers. The lovely customs that you think so much of, arecould you but read the hearts of these child peoplean unending horror,-fear of the future, fear of their 
enemies, fear of demons! Oh, Mary Kingsley! How is it possible for you, a woman of intelligence, to suggest that it were better if this demon-worship were preserved, and the natives left in what you call their innocence! Your weakness is the little wrong you know within your life, and therefore you do not see in others darkness dominant. I have known sin from early childhood and realize the difference of a Christian life from one that is without a Savior."

Low in the west the evening star was setting, while clouds of Heaven's constellations looked down upon the heart communion of two souls. To Mary Kingsley's eyes salt tears had come.

"Ma Okoyong, I admire you, the greatest and most Christian woman of this coast. I would give anything to have your faith, but I can't, I can't: when God made me, there was lost the part that one believes with."

Had Mary Kingsley then been won by Mary Slessor, and the two joined hands for Christ and Africa, it is difficult to say what might not have been done; but Mary Kingsley left, and shortly after died, and Mary Slessor sent a guinea as her mite for the proposed memorial to the other Mary.

Thirty years have gone by into the "Never never" since Mary Slessor first reached the Bight of Benin, and stepped ashore at Duke Town. Further and further inland she pressed the frontier of her influence, by way of Old Town, Creek Town, Ekenge and Akpap, Arochuku, Itu, Ikotobong, Use, Ikpe, and now she has reached her final earthly destination, Odoro Ikpe. The three mission stations close to the coast 


\section{I26 AFRICAN HEROES AND HEROINES}

she found when first she arrived have grown to twelve main stations and many out-stations. She has been government agent and vice-president of the native court, the only woman judge in the British Empire. She has been appointed an honorary associate of the order of the Hospital of St. John at Jerusalem for "meritorious services," honored by governors and governor-generals, by the King of England, by her fellowmissionaries and by the children of Africa she loved. She is sixty-six years old and her time of suffering and service, her time of earthly strenuous self-sacrifice is drawing to a close. Her skin is like parchment, gray her head, her shoulders bent. How many a time had not her body passed through the fiery furnace of coast fever! How many a time had she not shaken with the ague, shivering in that tropical heat, racked by malaria and dysentery! Her body, never strong, had, like a well-worn tool, come to the end of usefulness; her mind and will were still as strong as ever. What a pity that such a soul could not be given a new body -so it would seem to us with our finite minds! Were human life on earth the only aim and object of our being, then every life is but a tragedy. If, on the other hand, the teaching of the Christ be true and life on earth is but a time of preparation for higher service, the short-lived years of an apprenticeship, then the use that this woman, Mary, made of her life is part of an apprenticeship of heroes and of heroines that will be given wider spheres in the great Hereafter. The training of her will, the building of her character, the daily striving to do good and better, built up the 
soul of that poor weaver girl into a thing of noble stature. The stage which we are told consists of planks that mean the world, shows in the comedies and tragedies of theater naught but disjointed incidents of life. No life is comedy, though there may be comedy in life: true, many lives are tragedy, but some are not: no Christian's life is ever that, for in its very suffering is contained sublimest happiness. Christ is the great example who for the joy that was set before Him endured the Cross. That all-transcendent joy, that apotheosis, is the Christian's certain hope.

The men-murdering world war with its flood of horror reached the far seclusion of Odore Ikpe and caused acute suffering to the little gray-haired lady there, more suffering than her worn-out body was able to sustain, and there she breathed her last on earth surrounded by the children whose lives she had saved.

One of the stateliest processions Old Calabar had ever seen followed "Eka Kpukpru Owo" (everybody's mother) to the old cemetery so richly sown with white sand from Europe, on the Mission Hill at Duke Town. Old Mammy Fuller, who had loved Mary much, sat alone atop of the grave and hearing women wailing as the funeral procession approached, rose up and called out, "Do not cry, do not cry. Praise God from whom all blessings flow," while in the far-off northland a little friend of hero-Mary wrote at her departure:

"She who loved us, she who sought us, Through the wild untrodden bushlands, Brought us healing, brought us comfort, 


\section{I28 AFRICAN HEROES AND HEROINES}

Brought the sunshine to our darkness,She has gone-the dear white MotherGone into the Great Hereafter. Thus she taught and thus she labored; Living, spent herself to help us, Dying, found her rest among us. Let the dry, harsh winds blow softer And the river's song fall lower, While the forest sways and murmurs In the mystery of evening, And the lonely bush lies silent, Silent with a mighty sorrow." 


\section{CHAPTER V}

A Missionary and an Engineer-MACKAY of Uganda 


\section{ALEXANDER M. MACKAY}

1849 (October I 3th) Born at Rhynie, Aberdeenshire.

1859 Sir Roderick Murchison surprised at his skill in drawing.

1865 His mother died.

I867 Entered college in Edinburgh.

1870-1872 Teaching and studying engineering.

1873 (November Ist) Left for Moabit, Germany.

1876 (January 26) Two calls for foreign missiion work were sent to him.

1876 (April 27th) Sailed by S. S. Peshawur from Southampton.

1876 (May 29th) Arrived at Zanzibar.

1878 (June 13th) Reached Victoria Nyanza.

1878 (November) Arrived in Uganda.

1887 Driven out of Uganda.

1890 (February 8th at II p. m.) Mackay died at Usambiro.

"Thus, with somewhat of the Seer

Must the moral pioneer,

From the Future borrow;

Clothe the waste with dreams of grain,

And, on midnight's sky of rain,

Paint the golden morrow."

John Greenleaf Whittier. 


\section{CHAPTER V}

UNDER a sun awning, a thatched grass roof, resting on roughly cut wooden posts, Mtesa, king of Uganda, sat in his quaintly built royal chair. By his side on a camp stool, Stanley, his writing-case on his knees, was busily writing. Around them chiefs and sub-chiefs, slaves and native women, formed a background.

"Here is the letter," said the white man to the ruler of the land, "the letter asking the people of my country to send you teachers. I wish I could stay and instruct all your people in the ways of the white man and the white man's God, but I cannot do this, as my friends who have sent me to this country expect me to go on with my geographical and exploring work."

At this moment Linant de Bellefond, Stanley's friend, sauntered up to him. "I think I shall have to leave to-morrow," he remarked, "on my way northward down the Nile. Can I do anything for you?"

"Yes," said Stanley. "You can carry my mail if you will, and take this letter to the Editor of the Daily Telegraph in London. I'll write him a special note, asking him to publish this call for missionaries to be sent to Uganda."

King Mtesa, much pleased, showed his appreciation by providing carriers and food for the caravans of the two explorers when, shortly after, they left his land. 


\section{I32 AFRICAN HEROES AND HEROINES}

Through forests, swamps and open plains, by road and river, de Bellefond journeyed towards the Sudan. Months and months of travel in the wild tropical regions of the African forest belt had been hard on his nervous system. He was full of fever but soon (may be in a month or two) he would reach Khartum, travel through the healthy desert lands, to Egypt, and thus home. So he planned, but his destiny had been arranged far otherwise. Like Van der Deken, Mme. Tinney, Boyd Alexander and many others, he was to die in the Dark Continent at the hands of the natives.

He had reached the country of the Bari people, one of the Nilotic tribes. Whether his treatment of the natives caused by his nervous condition stirred up strife, or whether fear of the white, ghost-like traveler who suddenly appeared among them lead to the trouble, will probably remain unknown. This much is certain, that in a scuffle with the Bari tribesmen he received a blow on the head with a bludgeon-like, wooden club, and was killed. The servants ran away, and some of them finally found their way to Khartum, where Charles Gordon ("Chinese Gordon") was then governor. An intelligence officer who had heard the story of the death of a white man reported it to Gordon. A small expedition of investigation was sent, and de Bellefond's body found. The natives had not touched it, but had run away into the long grass. The body was decomposed, but on its feet were still the boots, and when these were examined there was found in one of them Stanley's letter to the Editor of the London Daily Telegraph. Reverently the explorer's body was de- 
posited in a grave, but Stanley's letter was taken on, handed to Gordon, and by him sent home to Europe. In due time it appeared-on November $15^{\text {th, }} 1875$. An anonymous donor immediately offered five thousand pounds sterling to the Church Missionary Society, asking that a missionary party should be dispatched to Uganda. Another fifteen thousand pounds were collected, and on the 2 2nd of April, I 876, the missionaries sailed from England to carry the Gospel to the heart of Africa, there to lay the foundations for the most successful foreign missionary enterprise of our day. The romance of African exploration and the modern history of the continent of Africa seem so entirely apart from the life of modern nations! They belong to the heroic age, to the times of Troy, of Siegfried, Roland, and the Round Table.

On the I $3^{\text {th }}$ of October, I849, in the Free Church Manse of the parish of Rhynie, in Aberdeenshire, a boy was born, named after his father, Alexander Mackay, who was destined to become the spiritual father of a nation. His father (who was an LL.D. besides being a minister) himself educated his boy, until the latter reached the age of fourteen. In 1864 young Alexander was sent to the grammar school in Aberdeen. Early the child had shown a strange liking for books that many other boys would not relish. Milton's "Paradise Lost," Russell's "History of Modern Europe," Gibbon's "Decline and Fall of the Roman Empire," and Robertson's "History of the Discovery of America" were his book-companions when he was seven years old-at an age when a modern 


\section{I34 AFRICAN HEROES AND HEROINES}

child would read "Alice in Wonderland" and "Robinson Crusoe," or perhaps "Strubel Peter."

For years his mother had prayed that little Alexander might give his heart to the Lord and become a servant of the Master. It was through her death that the great change in his life took place. Her boy could not be got home from Aberdeen in time to see his mother before she passed away. She gave her Bagster's Bible to the nurse with instructions to hand it to her son on his arrival, with a text of three words, the words of St. Paul, the apostle, "Search the scriptures." This passage, which was specially marked in the Bible, became to him as a message from God. It was in 1867 that father and boy removed from Aberdeenshire to Edinburgh, and it was there that the son passed the university entrance examination with highest honors, being at the head of all the young men going up from the United Free Church. Three years of study at Edinburgh university gave him a solid educational foundation. It was his father's wish that his son should prepare for the ministry, but young Mackay was far more interested in engineering than in pulpit oratory. When through with his college course, he served in the morning as a teacher, and spent the afternoons in the engineering yards at Leith. On Sunday morning he worshiped at the church of Horatius Bonar, and on Sunday afternoon went among the ragged children and outcasts in the slums, seeking to help the most needy. $\mathrm{He}$ also became interested in foreign missions, and as the persecutions of the Christians in Madagascar were much talked about at 
that time in missionary circles, he offered himself for work there-but nothing came of this.

It is said that a canny Scot has his eye always on the "main chance," that is, the chance of money-making. But the great men of Scotland have been remarkably free from this weakness. Alexander had many opportunities of becoming a rich man, but he turned away from these, saying, "It is not to make money that I believe a Christian should live." Once he was offered an equal partnership in a prosperous engineering enterprise in Moscow (Russia). He "turned this down" to become a poorly paid missionary in Central Africa.

On October I $3^{\text {th }}$, I 874, Alexander Mackay wrote in his diary, "Twenty-five years of age! Bless the Lord O my soul for all His goodness! Man is immortal till his work is done. Use me in Thy service alone, Blessed Savior." This was the prologue of that remarkable man's life.

A year later Mackay offered to the Church Missionary Society of England to become the lay superintendent of a settlement for liberated slaves which was then being organized at Mombassa, East Africa. This was the same year in which Stanley reached Uganda. Thirteen years before, the first white man, Captain Speke, had set foot in that kingdom of the lakes. Instead of going to East Africa, Mackay accepted a lucrative appointment as chief instructor in an engineering firm sixty miles from Berlin, in Germany.

In Berlin the young Scotchman made a number of 


\section{AFRICAN HEROES AND HEROINES}

friends. He was a welcome guest in the house of the court preacher and, desiring to make a contribution to the Christianity of Germany, he translated one or two of Dr. Bonar's devotional works.

Thus, physically and mentally, he was at work in Europe-but the lure of Africa had reached his heart. On the Ist of May, I 874 , he had written in his diary, "This day last year Livingstone died-a Scotchman and a Christian, loving God and his neighbor in the heart of Africa. Go thou and do likewise." The years 1874 to 1876 were years of restless longing for an adequate life's work.

It was in 1875 that Stanley wrote to the editor of the Daily Telegraph, calling on Christian Britain to send missionaries to Uganda. On December I 2th, I 875, Mackay wrote to the Church Missionary Society, "My heart burns for the deliverance of Africa, and if you can send me to any one of those regions which Livingstone and Stanley have found groaning under the curse of the slave hunter I shall be very glad." The question of foreign missions had to be squarely faced in the life of Mackay on the 26th of January, I 876 , when two calls came to him, both summoning him to Africa,- - one from the Church Missionary Society, to join a party that was to be sent to Africa in response to Stanley's message; and the other from the Free Church of Scotland, to become the head engineer on a missionary steamer on Lake Nyassa. He felt the former call to be the more pressing, and wrote to the Church Missionary Society that he was ready to go. 
Time fails here to tell of the fitting out of the missionary party, of the departure from England (27th April, I 876), the arrival on the East Coast of Africa, and the many and varied experiences Mackay had, before he finally reached Uganda. Suffice it to say that whatever Mackay did he did thoroughly. There was no road to Uganda, so his first work on his arrival in East Africa was to build such a road from Mpwapwa, two hundred and thirty miles inland. It was no plaything, this. His companions retired, one after another, on account of ill-health, and the last two were murdered, but Mackay went on steadily and fearlessly. For two years he toiled north-westward, towards the great lake.

Lieutenant Smith and Mr. O'Neill, his two companions, had transported a sailing boat to Lake Victoria, but they were killed; and when Mackay reached that great inland water basin, at the south end of it, at a place called Kagei, he found that the Daisy had been destroyed by white ants, hippos, and the heat of the sun. So, after building the road, he built a boat; and when this was finished, he made friends with the murderer of his two companions, Chief Lkonge, on the Island Ukerewe.

The call to Uganda had come to him in January, I 876. In November, I 878 , Mackay entered Ntebe, the harbor of Uganda, and five days afterwards was in the capital of the country, Rubage, a place now known as Mengo.

Mtesa, the Kabaka (king of the country), welcomed him, and his real life-work began. 


\section{I38 AFRICAN HEROES AND HEROINES}

Like Livingstone, Brooke and Grenfell, Mackay was not a genius, but he was an idealist and a hard, conscientious worker. Perhaps these terms are synonymous, for a genius has been defined as "a man who is willing and able to take endless pains."

Let us spend an average day with Mackay now, that we may realize what foreign mission work is.

The morning star is sinking in the west, and the eastern horizon is tinted with the faintest streaks of dawn, when in his hut on Kampala Hill the white man throws off his blanket. He gets off his wooden couch and takes a good stretch, for the bed is not of down, and bones get stiff with lying on hard knobs. The mosquitoes have been worrying him through the night for, in spite of careful tucking in the net by way of precaution, the bloodthirsty trials always manage to enter. A missionary wag suggested but the other day that a sound way to secure a respite would be to make a hole in your mosquito net after you had lain down, and when it was full of the mosquitoes in your room, then slip from your bed, tie up the hole, and sleep in quietness-outside! But a missionary intent on his work has usually no time for such considerations. His head is in a wash-basin to get the sleep out of his eyes -a quick rub down and he climbs into his clothes. There are not many of them, and the toilet takes less than five minutes.

In the meantime his native boys outside at the fire have yawned, stirred up the embers, got the kettle on, and prepared some slow poison in the shape of tea or coffee. Ground millet is cooked into a porridge, and 
as the blinding disc of day rises above the horizon (for there is no rose-fingered Eros in Central Africa), presently the missionary's boys and some men from the native huts near by come together for morning prayers-some half a dozen of them. A tuckle made of grass mats, and thatched with the same material serves as chapel. The hard beaten floor is covered with rushes or mats. There are no pews, or forms, or chairs, only a stool for the white man. They repeat together the Lord's Prayer: some short passage from one of the Gospels is read-another prayer, the benediction, and the service is over.

While the day is still cool the missionary works outside with some of his native boys. The garden needs attention; some bushes and new trees are planted; or in the blacksmith's shop axes, hoes and hatchets that need mending (perhaps some have been sent by the chief) are put into good working order. And thus three hours of the day go by.

It is 9 o'clock. From the valley by the bush path come two elderly natives dressed in bark cloth-a long brown garment looking something like a Roman toga. And now the books are got out under an awning in front of the chapel, at a table made by the missionary with his own hands from packing cases, for stools they have the sawn off logs of wood,- - and he and his two native teachers sit down. The vocabulary of the language (consisting of about 3,00o words) is finished: the rudiments of a grammar have to be gone through again. Besides the Baganda language the teachers speak Suahili, and the missionary has acquired profi- 


\section{AFRICAN HEROES AND HEROINES}

ciency in this during his two years in the coast region, so the conversation is carried on in that language. Prefixes and suffixes, conjugations and declensions, diminutives and superlatives are not a little puzzling at times; the structure of the Bantu languages is entirely different from the Latin, Germanic or Semetic tongues. An hour of this is about as much as can be managed at a time. Then comes translation work, and new words, and other difficulties.

What is the word for "substitute"? For "cross"? For "spirit"?

If not careful the missionary is frequently led in his translation work into serious trouble. For years the missionaries in another country in Africa had used the word that meant "evil spirit" for the "Holy Spirit." In another language the words for "heart" and "dog" are almost the same; it would never do, if you want to tell the natives that they must have a new heart, to tell them that they must have a new dog! Behind a number of words a query is made. These words are to be investigated further. A chapter of the Gospel, translated the previous day, is revised, and a new chapter is translated in the rough.

The work is not yet finished when, from different directions out of the fields and the forests, come the halt and the sick and the blind, for by this time the missionary has gained the reputation that he is as good as the witch doctor, if not better, in dealing with the ills evil people or evil spirits have inflicted on the bodies of their enemies. The old-fashioned way of getting the witch doctor to lay your enemy by the heel, 
and have him dealt with by poison ordeal, does not always cure the disease, and so the white magician is consulted. The two "High Cs" for which the native has the greatest respect are calomel and castor oil, and no missionary is without them if he can help it. Sometimes the trouble is such that the missionary, shaking his head, has to confess there is no help, and sometimes he is put on his mettle. The poor man has not studied surgery, and here is a man with an ulcerated spear-wound in his lower extremity, and mortification has set in! The leg must be amputated if the life is to be saved. The wounded man has brought some relatives along. The white man tells them that their friend will have to die, and he is besought to do something for the suffering brother.

"His leg will have to be cut off, and I cannot do this. If I do, he may die under the operation. I have never done such a thing in my life."

"White man, you can do anything you want to."

Yes, the white man is such a wonderful animal that if he should take it into his head to fly over the treetops, the natives would not be astonished. After much consideration the white man gets out of his carpenter's chest a small saw, he gets his razor, a pair of scissors, strong silk and a darning needle, puts them into a pot and boils them (for he has heard that this is necessary), washes the wounded leg with antiseptic, has the native tied onto a bench,-and operates. But what a horrible business! A missionary who was in just such a predicament vowed that he would go right home to Europe and study surgery, and did so. 


\section{I42 AFRICAN HEROES AND HEROINES}

"White man, I cannot see," comes from the lips of an old woman, perfectly blind.

"Yes, poor mother, I am afraid you will never see again. But if you come to the Light of the World, your soul will get eyes that will see beyond the grave, hope, happiness and heaven."

"White man, teach me about the "Light of the World.'" And so with the sick around him he tells them the Gospel, not from a pulpit, nor from a platform, but the way the Lord of Life taught and they who followed Him, his Apostles.

Thus hour follows hour in busy work, with no end of difficulties and problems to be solved impromptu.

In the afternoon the chief may call or send messengers, or he may have to visit the king's compound. Letters have to be written and reports sent home, and by that time night comes with its evening tub and dinner. The missionary needs no sleeping-draught at half-past eight, or maybe nine o'clock, when he seeks his couch and sinks into a dreamless slumber, committing his soul to God's keeping, and thanking Him for the privilege of service that is worth while.

Time after time the authorities at home begged Mackay to return to England for rest. Mr. Eugene Stock, the editorial secretary of the Church Missionary Society, realizing the value of Mackay's life, urged him to spare himself and take a holiday. To this our hero replied, "What is this you write! Come home? Surely now in our terrible dearth of workers, it is not the time for any one to desert his post. Send us only 
our first twenty men, and I may be tempted to come to help you to find the second twenty."

Stanley, who said of Mackay that he was the greatest missionary since Livingstone, writes about him in the days when Mackay passed through deep billows and shadows, "He has no time to fret and groan and weep (and God knows if ever man had every reason to think of graves, and worms, and oblivion, and to be doleful and lone and sad, Mackay had), when, after murdering his Bishop and burning his pupils, and strangling his converts, and clubbing to death his dark friends, Mwanga turned his eye of death on him, and yet the little man met it with calm blue eyes that never winked! To see one man of this kind working day after day for twelve years, bravely, and without a syllable of complaint or a moan amid the wildernesses, and to hear him lead his little flock to show forth God's loving-kindness in the morning and his faithfulness every night, is worth going a long journey for the moral courage and contentment that one derives from it."

Among many writers on Uganda, hear but these three, on what Uganda was, and what Uganda isand that, the result of the life of Mackay.

Stanley, in 1876 -before Christian missions began in Uganda-

"Thievish knaves. Violence is rife. Human life cheap. Frequent tortures. Bloody superstitions abound."

Pilkington, in I 896. 


\section{I44 AFRICAN HEROES AND HEROINES}

"A hundred thousand evangelized-half able to read for themselves; two hundred buildings for worship; two hundred native evangelists and teachers supported by the native church; ten thousand copies of the New Testament in circulation; six thousand souls eagerly seeking daily instruction; the power of God shown by changed lives."

Winston Churchill (former British Colonial Minister) says that he never saw better order or happier homes than in this central region of Africa, where a few years ago pioneer missionaries (Bishop Hannington) were mercilessly put to death by natives.

For only fourteen years did Mackay's life work last-nay not last, but in fourteen years it began and goes on for ever. On April I4th, I 890 , the news was telegraphed from Zanzibar to England that the earthly life of Alexander Mackay had come to an end.

The last message from him, which reached the Church Missionary Society House ten days later, contains this clarion call-

"You sons of England, here is the field for your energies. Bring with you your highest education, and your greatest talents. You will find scope for the exercise of them all. You men of God, who have resolved to devote your lives to the cure of souls of men, here is the proper field for you!" 
CHAPTER V (Continued)

The lion-headed Bishop-Tucker 


\section{BISHOP ALFRED R. TUCKER}

I849 Bishop Tucker was born.

I890 (April 25th) He was consecrated Bishop of Uganda by Archbishop Benson.

When he arrived there were 200 Christians: when he left 18 years later there were 62,867 church members. 1893 The first deacons were ordained.

1896 (May 3ist) The first native priest was ordained. I908 Left Uganda-when he arrived in Uganda he found one Christian place of worship: when he departed there were I,O70.

1914 Died as Canon of Durham Cathedral. 


\section{CHAPTER V (Continued)}

BEFORE going on to our next hero, let us study for some minutes more the missionary history of Uganda. It was just a year after Mackay had reached Uganda that the Roman Catholics began their work there in opposition to the English Church Mission, and not a little to the bewilderment of King Mtesa.

M. Lourdel was the spokesman of the Roman Catholics. This was the fourth distinct religion in Uganda. First there was the heathen worship of Lubare; then the Moslems tried through their religious emissaries and traders to win Uganda to Islam; then came Mackay and his mission of the Church of England; and, lastly, the French Romanists.

Mtesa, like King Khama, Lobengula, and Lewanika, was among the great chiefs of Ethiopia. He was sharp and strong, and inclined to be a Christian. He had difficulty in making his choice with four religions being urged upon him. The old chiefs and the mother of the king at last prevailed, and won him back to the faith of his fathers-to Lubare-and in a great assembly of his people he rose, and definitely made this statement, "We will have nothing more to do with the religions either of Arabs or the white men, but shall return to the religion of our fathers."

In I88I, Mtesa's envoys-the men he sent as messengers to Great Britain, returned, and with them came 


\section{48 AFRICAN HEROES AND HEROINES}

Mackay's companion, Mr. Wilson. Mtesa's men told of what they had seen, and for a time the English missionaries were again in favor.

It was on March I 8 th, I 882 , that the first five natives were baptised as Christians in Uganda. All promised well, but hardly had two years gone by when King Mtesa died and was succeeded by his son Mwanga. At that time quite a congregation of church members worshiped at Campala. In 1885 , on July 26 th, a hundred and seventy-five gathered at the mission for prayers, and thirty-five communicants partook of the Sacrament. In seven years the Church had been established in Uganda. As after days of sunshine comes the thunder, and summer's cooling rains do rarely come without a storm, so, in the building of a church, there follows, after a time of quiet and gradual growth, the storm that ushers in the harvest. It was five days after July the 26 th, that the first three martyrs were murdered in Uganda. They were tortured and then burnt alive. Here is the story from the pen of R. P. Ashe, one of the early missionaries in Uganda.

"The three boys-Seruwanga, Kakumba, and Lugalama-were led away to death, a mocking crowd following them. 'Oh, you who know Isa Masiya' (Jesus Christ), said Majasi. 'You know how to read; you believe you will rise from the dead? Well I shall burn you and see if it be so.' Then the prisoners are seized, and a scene of sickening cruelty is enacted. Some lay hold of Seruwanga, others of Kakumba, and others of Lugalama, brandishing 
their long curved knives. Seruwanga has committed his cause to Him who judgeth righteously, and the cruel knife cannot wring from him a cry; bleeding he is cast into the fire. Kakumba, too, undergoes the short agony and the flame. And now the saddest scene of all. Majasi bids them treat Lugalama as they treated the others. Surely even these men, hardened by frequent executions, have never had to do a deed like this! They come nearer, and he cries out, 'Oh, do not cut off my arms; I will not struggle-I will not fight! Only throw me into the fire!' Surely this was the saddest prayer ever prayed on earth!

"The butchers do their work and mar what was so wonderfully made; and the poor bleeding boy is placed on the framework, that the slow fire may finish what the cruel knife began. A wail of anguish goes up, becoming fainter and fainter-a last sob, and then silence."

All through that year and the next, persecutions and the killing of the Christians were continued. In October, I886, the newly appointed Bishop of Uganda -the manly, noble Bishop Hannington-was murdered by Mwanga's men, before ever he had seen Mwanga's city, Mengo. 'Twas fear, so people said - fear of the strong white bishop-that caused the chief to give the order for his execution. So wrong done breeds other wrong, and on from bad to worse.

In 1887 Mackay himself was forced to flee, and crossed the lake to Usambiro. And now the Moslems 


\section{50 AFRICAN HEROES AND HEROINES}

got control. They drove out all the Protestants and Roman Catholic missionaries, and in the end the King was driven out too, and had to eat the bitter bread of exile.

Time fails here further to tell the ups and downs, and revolutions, of fightings, pros and cons. It is only in main outlines that we can trace the phenomenal success of Christian missions in Uganda. We must leave the valleys and the woods, and move from hill to hill; or, standing back, get the perspective of the happenings in the land.

Before us rises the second hero of Uganda, like some great mountain peak outstanding in the distance.

After three weeks' journey from his homeland, England, Bishop Tucker reached Mombassa on May I4th, I 890 , and thence wrote on June the I Ith to Uganda's king the following letter.

"To Mwanga, King of Uganda, with compliments,

"Having been called in the providence of God to be Bishop of the Church of God in East Africa, I now write to you as one desiring to see you, and purposing shortly to come to you.

I come with all goodwill and kindness in my heart. I desire only your good and the welfare of your people. I am your friend and because I am your friend I am anxious that both you and your kingdom should enjoy the blessings of the Gospel of Christ. I am therefore bringing teachers with me. They love your people as I do, and are your true friends as I am. We believe that you will wel- 
come us and do all in your power to help us in our work of teaching, and so making your people happy and prosperous.

But what is the use of saying more now when I have so much to say and hope so soon to see you. Trusting that this letter may find you in good health, I remain with many salaams, your true and faithful friend,

Alfred,

Bishop of East Equatorial Africa."

The Sultan of Zanzibar also wrote to Mwanga,-

"I have to inform you that your friend, the Right Reverend Alfred Robert Tucker, Bishop of the English Church, is coming to you. $\mathrm{He}$ is one of our best friends. What I wish from you is that when he reaches your place you may receive him with full respect, and prevent any one doing him an injury. We wish to hear from him on his return that he was very well received and treated by you, because he is one of the best of our friends, and whatever good you may do to him, will be considered by us as if the same good were done to us by you. Let it be known to you that the English and ourselves are all one. This is what we wish from you. Please let us know if there be anything that we can do for you.

Written by his slave,

Abdul Aziz Ben Mahommet." 


\section{I5 AFRICAN HEROES AND HEROINES}

The Bishop reached Uganda in December. $\mathrm{He}$ found a church there, small in numbers-two hundred, hardly more-but its membership included men and women of spiritual power and devotion-men that had stood the test, been through the fires, they were refined, and real Christians. Where can we find in the old Christian countries a church that counts among its members two hundred men and women who are ready and prepared to die at any moment for the faith?

Three times the writer met Bishop Tucker, once in Uganda and twice in Great Britain. Among the many leading men of the world whose faces express willpower, character, leadership-Tucker's was unique in its way. I have seen him sitting in King Mtesa's chair which stood on the verandah of his mud-house in Mengo. His grave face gave one the impression of a lion at rest-broad forehead, heavy hair, side whiskers, determined mouth. As a rule he moved slowly. Had he lived in the days of the early Saxons or the Goths, he would have been a chief among his people. Among his Baganda he was loved and respected; no outward trappings, gowns or crowns, were needed to characterize him as a leader. The house in which he lived for fifteen years was built of clay, whitewashed and grass-thatched, and had cost him (so he told the writer) thirty pounds (\$1 50 ).

The matter that troubled him most in his later days in Uganda was the introduction of saints' pictures, of which he had accumulated a whole drawer-full, given to him by men and women who had come to his church from the Roman Catholics. 
"It is too bad," he said, "to lead these simple people, who are just beginning to give up the worship of sticks and stones, to worship pasteboard and celluloid,- - for that is what they are actually doing. To replace the one by the other is no advance unless we succeed in leading the natives from the worship of the physical to the spiritual, from demons and natural pheromena to Jehovah Jesus, the Creator, Savior, and Judge of the world. We shall give into the hands of Mohammedan propagandists arguments and tools which they will be only too ready to use, denouncing the Christians as being as idolatrous as the heathen."

Under Bishop Tucker's guidance the Anglican Church in Uganda grew from a membership of two hundred in 1890 in such a phenomenal way, that that same church in 1907 supported over three thousand native clergy, teachers and missionaries.

It was in 1907 that the writer, on a journey round Africa, coming up the East Coast, left the steamer at Mombassa, and by rail journeyed through British East Africa (the grandest game garden in the world) to Victoria Nyanza, and crossed it to Uganda. From Entebbe, on the lake, relays of runners took him in a rickshaw along a beautiful road of something over twenty miles, to Mengo, the capital.

The Bishop of Uganda showed him the sights. He took him to the hospital, where two brothers (Drs. Cook) were fighting that demon of Central Africathe sleeping sickness; took him to see the school for the sons of chiefs (there is a school in Uganda where only the sons of chiefs are educated-chiefs of the 


\section{I54 AFRICAN HEROES AND HEROINES}

surrounding countries); and took him up the Royal Hill of Mengo to the king's house, a modern bungalow, where the king, who is quite keen on games such as tennis and cricket, made him sign his name in the visitors' book. The young king was only a boy then, and when told by the Bishop that the writer was interested in missions in the Sudan, said he knew something about the Sudan and how much missions were needed there. After an hour's interesting conversation Bishop Tucker and the writer wended their way down the hill by a narrow lane, when the Bishop laid hold of his arm and said, "Do you remember the stories of David Livingstone and Stanley,-how Stanley not only found Livingstone, but found Livingstone's God and the message Livingstone was carrying to Central Africa; and how, wherever Stanley afterwards journeyed, he was in the habit of speaking to the chiefs about the God of David Livingstone, and the Gospel?"

"Yes, I remember."

"Well, when Stanley got here to Uganda, he spoke to the chief about these things, and the chief liked the message so well that he said to Stanley, 'You stay here with me and teach me and all my people about these things.' But Stanley replied that this was impossible. $\mathrm{He}$ would have to go on and do the work for which he was sent to Africa, but if the chief so desired it, he would write a letter to the white man's country, asking them to send a teacher to Uganda. So the famous letter was written to the editor of the Daily Telegraph, asking the British people to send missionaries to Uganda. The Church Missionary Society of 
England acted in response to this call and sent out a party, and as a member of this party a Scottish engineer by the name of Mackay arrived here in $1877 . "$ "Now Mackay was not much of a preacher," went on the Bishop, "but he was a man who could live a Christian life, and to live a Christian life is much more difficult than to preach. A number of young fellows were drawn to Mackay (true Christian manliness always attracts) and through Mackay's influence they became Christians. Then the old king died, and his son Mwanga became the ruler.

"Now Mwanga was a scoundrel. One night they had a great feast, and after drinking much millet beer (called busa in Central Africa) one of the sub-chiefs of the tribe, sitting next to the king, said, 'Chief, you think you are the big man in all this country?'

"'Yes,' said the chief, 'I am.'

" 'You think everybody obeys you?'

"' 'Yes,' said the chief, 'everybody obeys me.' And everybody did, for disobedience meant quick or slow death.

"' 'Well, they don't,' said the sub-chief.

" 'Who does not?' asked the king.

"Over there on the Campala Hill, where the white man lives those young fellows that go every day to the white man-they don't belong to you any more. They don't obey you any more. They belong to the white man now.'

" 'No, they don't,' said the king.

"' 'Yes, they do,' said the sub-chief.

" 'Well, bring them here, and we'll see.' 


\section{56 AFRICAN HEROES AND HEROINES}

"The young men were sent for. It was late at night when they reached the hall of feasting. They were pushed forward before the king, who looked at them and said, 'Who are you?'

" 'We are your slaves.'

"Who is your chief?'

"'You are our chief, mighty one.'

" 'Oh, I am your chief am I? and who is your God? (Many of the native chiefs of Central Africa, like the Roman Emperors, demanded divine worship.)

"A moment of hesitancy and then the answer comes from the leader of the boys, 'Jehovah Jesus.'

" 'Who is your God?'

" 'Jehovah Jesus.'

" 'Who?'

" 'Jehovah Jesus.'

" 'Take them down into the valley, and burn the lot of them.' And by the same path which you and I have just come down by, the young boys were driven into the valley near a swamp, tied to trees and stakes, and brushwood was heaped around them. After they had been cruelly tortured, the torches were applied, and then out of the flames came the old song of the martyrs,-

'Worthy is the Lamb that was slain!

Christ is our Life! Death is our gain!'

The flames rose higher, and there was silence."

"Come along now, Doctor," continued the Bishop, and we went down into the valley past the martyrs' monument, up the next hill, and on the brow came to a great building. 


\section{BISHOP ALFRED R. TUCKER}

"I suppose this is your cathedral," said the writer. "Yes."

"May we go inside?"

The Bishop clapped his hands. A boy came running. He was sent for the key, and while we were waiting the writer said,

"Bishop, why do you not leave the door of your cathedral open so that people can come and meditate and pray in the cool shade of this magnificent building?"

Said the Bishop, "Doctor, that would not work here. My difficulty is not getting people into church but getting them out of it. If I did not lock the door of the cathedral sometimes, I'd never get the people out. They'd stay there night and day. You see Christianity is fashionable now here in Uganda."

By that time the boy had come with the key. The door was unlocked, and into the lofty building (that seated over 3,000 people) the Bishop and the writer went alone up to the altar for prayer. Before leaving the conversation continued.

"Bishop, how much money did the missionary society spend on this cathedral?"

"The missionary society did not spend anything on it."

"But how was it built?"

"The princes of the royal blood, the princesses, and all the people came and worked, and together we built the House of God."

That cathedral was burnt down, but a new one has been built since that seats over 5,000 people. There 


\section{58 AFRICAN HEROES AND HEROINES}

were no pews or forms, but only grass mats, and a few stools on which the people sat during the Service.

"Bishop, you must have quite a number of native workers. How much does the Missionary Society spend on them?"

Then came a most startling answer from the Bishop's lips. "The missionary society does not spend a penny on the native workers. We have three thousand clergy, teachers, and missionaries supported by the native church of Uganda."

"And how long is it, Bishop, since Mackay arrived here?"

"Thirty years."

This is the miracle of modern missions! 


\section{CHAPTER VI}

The Smoke of a Thousand Villages, as seen by Robert Moffat, of South Africa 


\section{ROBERT MOFFAT}

I795 (December 21st) Born at Ormiston, Scotland. I812 Gardener at Donibristle. 1813 At High Leigh.

1816 (October) Sailed for South Africa.

I 8I 7 (January) Reached Cape Town.

1819 Married Miss Smith.

1838 New Testament translated into Bechuana language. I 839 Returned to England on furlough.

I 840 David Livingstone was called by Moffat.

1843 Moffat was back in South Africa.

1859 Moffat opened a new station at Inyati.

1870 Returned to England.

I 878 Received the freedom of the City of London.

I883 (August Ioth) He died and was buried in Norwood Cemetery. 


\section{CHAPTER VI}

Moshete of the Bechuanas, known among his home people as Robert Moffat, was the pathfinder for the missionaries of South Central Africa, the friend of the great king Mosilikatse of the Matabeles, and of Cetewayo of the Zulus, the father-in-law of David Livingstone, and the venerable spiritual father of many.

Moffat was born in 1795 at Ormiston, East Lothian, Scotland. Like many another great man he ran away to sea, desirous all too early to find his own sphere in life. It is only degenerates who depend on their parents after they are full-grown, and it is a healthy sign when the young want to fly out of the nest before their time. There is danger in this, but it indicates health and independence,-two important factors in human life. Robert Moffat had a hard time of it as a sailor boy, and, disgusted with it, returned home, to the great joy of his parents. Like other Scotch youths, he was brought up on porridge and proverbs, good for brawn and brain. The "Shorter Catechism" was his first book, the title-page of which contained the A, B, C, and from it he learned to read. At the age of eleven he was sent with his brother Alexander to Mr. Paton's school in Falkirk, but only stayed six months. He had tried sailoring and that did not suit him; now he tried horticulture. He had to rise at 4 o'clock even in the depth of winter, and was fed on hard work 


\section{I62 AFRICAN HEROES AND HEROINES}

and little else. He learnt that life was more than a Highland Fling. After his apprenticeship was ended he secured a situation with the Earl of Moray at Donibristle.

"Say, you boys, stop rocking that boat, or we'll be in the water!" But the boys did not stop, and suddenly the gunwale on one side went under, over went the boat, and Robert found himself in the waterunable to swim. He was almost drowned, but at last managed to get ashore, and the other boys thought it a huge joke. Robert set his teeth and determined to learn to swim. Before working hours he got up morning after morning and with no one near taught himself breast strokes, and side strokes, how to tread water, and how to float. When he was almost drowned none of the other boys had tried to save him: he bided his time, hoping for an opportunity to pay back one of his friends in a different coin.

"Stop rocking that boat!" The boys did not know that Robert had learnt to swim and they wanted to frighten him. "Didn't I tell you last time that you would upset the crazy craft, and here you are at it again!" His chums only laughed and rocked the harder, until over went the boat. With screams of delight all leapt into the water, including Robert. But -as the boat turned turtle one of the sides going down hit one of the boys on the head and stunned him. The others saw it as they were making for the shore. The boy who was struck would have been drowned, one of his hands came to the surface and opened and closed convulsively, when Moffat laid hold of it, threw the 
boy on his back and, swimming, lugged him to the land. The boy was gasping, but evidently not much the worse for his experience, when Moffat turned to the others, and in his wrath said, "You pack of bullies and cowards! You are no good, and I will have nothing more to do with you. You almost drowned me last time, and you would have let Charlie drown!" and helping Charlie to his feet he marched off with him in high dudgeon.

Work in Scotland in those days was ill-paid, and after a year at Donibristle Moffat secured a better position with a Mr. Leigh in Cheshire (England). He promised his mother before he left that he would read a chapter of the Bible every morning, and he fulfilled his promise.

Among his acquaintances at High Leigh were some Methodists, and after the manner of the Methodists, they tried to win Robert Moffat to their view of thinking. In this they partly succeeded, at least to the extent that Robert Moffat resolved to serve the Lord Christ, and, after a missionary meeting in Manchester which he attended, he offered himself to the London Missionary Society for foreign service. His education was not of the best, though he had succeeded, in the little while he was at school, in assimilating a good deal of knowledge. Now he spent some time in study, at the suggestion of the Committee of the London Missionary Society, and was ordained on the 3 oth of September, I816, at the age of twenty-one, in Surrey Chapel.

In those days missionaries did not go out for terms 


\section{I64 AFRICAN HEROES AND HEROINES}

of two years; Moffat's first period of work in Africa was twenty-three years. A Miss Smith to whom he had been engaged to be married wanted to accompany him to the field, but her parents would not permit this. She followed him three years later, and they were married in South Africa on the 27th of December, I 8 I 9.

Many difficulties awaited the determined young missionary in his new sphere of work among the Bechuanas. Before studying the language of the natives he had to learn Dutch, which was understood by some of the people.

The witch doctor of the tribe was his sworn enemy. In days of drought the missionary was a convenient scape-goat for the witch doctor. First it was the salt in the white man's wagon, and then the chapel bell, that bewitched the weather. At last the trouble came to a head. The chief, followed by a number of fully armed men, came to the mission station and told Moffat, who was busy mending a wagon, that it was time to inspan his oxen and get out of the country. They had had enough of him. They were quite prepared to resort to violent means. Everything was at stake. The moment had come when the missionary had to throw his life into the balance. In the hand of the chief quivered the spear. Moffat faced him; with his left hand he opened his waistcoat, while his wife, with a baby in her arms, was watching the crisis from the door of their cottage.

"Now then," said Moffat, "if you will, drive your spear to my heart; when you have slain me, my companions will know that the hour has come for them to 
depart." Here was aggressive non-resistance! What could the chief do? With a significant shake of the head he turned to his companions and remarked,

"These men must have ten lives when they are so fearless of death. There must be something in immortality."

How vividly all this reads in Moffat's own words, reproduced from the report he sent home to his Mission board at the time. He closes the incident by observing, "The meeting broke up and they left us, no doubt fully impressed with the idea that we were impracticable men."

Ten years went by without apparent result from his missionary efforts. He could speak freely now to the natives in their own language. They had learnt to trust their white friend who had left his far-off home to come to their country and teach them. They had begun to love him.

One Sunday Moffat's soul was burdened with the realization of the barrenness of his endeavors. He poured out his heart in prayer, and when the service began he rolled off the burden of his soul on to those of his hearers. The eyes of strong men opened wide, they filled with tears; they cried like children. The chapel became a place of weeping and some fell down in hysterics. A new, larger church, a temporary one, had to be built. People came to see the "new thing." In May, I 829, the new chapel was opened, and on the first Sunday in July of that year, six were baptised and twelve were at the Communion Service in the evening,-in the Church of the first-born at Kuruman. 


\section{I66 AFRICAN HEROES AND HEROINES}

In I 839 Moffat took his first furlough, and remained at home four years, telling of his work. He interested David Livingstone in Africa, and was back in Cape Town in April, I843, after a sea voyage of three months. At Kuruman the Moffats were welcomed by Livingstone, who had preceded them to Africa. Shortly afterwards this young man asked them for the hand of their daughter Mary, gained their consent, married her, and then began his magnificent explorations in Central Africa.

For many years Robert Moffat worked at the translation of the Bible into the Sechuana language. He needed a rest, but instead of going to the Cape or home to England, he decided to look for his daughter and son-in-law from whom he had not heard for some time, so journeying northward through bush-land, and plains, and across rivers and rocky regions, he came to the land of the Matabele. Now the chief of the Matabele, Mosilikatse, with whom he had been friendly fifteen years before, gave him a royal welcome. But poor Mosilikatse was suffering from dropsy, and was unable to walk. Moffat in his treatment of the chief (for Moffat was not only a sailor, a gardener, a preacher, but also a doctor) was so successful that his friend, the king, was almost fully restored. The quest on which Moffat had gone, namely to get news of his children, was at first unsuccessful, so the chief suggested that they should both go on together and find Livingstone. A host of men went out with them, but when they got to the borders of Matabeleland it was found that provisions could not be secured for such an 
army. Moffat therefore arranged for some of the tribesmen to go on with supplies for his children until they should find them. They did find Livingstone far to the north, on the banks of the Zambezi River.

Moffat returned to his own station and finished the translation of the Old Testament, the New Testament having been completed before his furlough in 1839 .

In I 855 when Moffat was sixty years old, at a time in life when the work of most men is finished, this great white-bearded and white-haired man set out with three other missionaries to open a new station far inland, at Inyati. Journeying in those days was not as easy as it is to-day. Be it remembered that Moffat was some six hundred miles away from Cape Town, and the only means of transportation was by ox-wagon. One of Moffat's sons was in this pioneer party, and it was the privilege of the writer to know this son personally. (He was a member of the first South African Sudan Committee.) When the new station was established and in working order, Moffat said good-by. The last Service was crowded with warriors of the tribe who had come together to hear, for the last time, their Moshete speak of the great things of God.

He went back to Kuruman, his old station, where his wife was waiting for him, and there he worked on, old in years but young in spirit, until he attained his fiftieth year of missionary service.

The Directors of the London Missionary Society urged him to return to England, and as he was troubled a good deal by cough and sleeplessness, he 


\section{I68 AFRICAN HEROES AND HEROINES}

at last agreed to do what the Missionary board desired, and returned to Europe. On Sunday, the 2oth of March, I870, Robert Moffat preached for the last time in the Kuruman church, and on the Friday following, he and his wife took their departure. Three months' journey across the Karoo and the South African veldt brought them to Cape Town, and six months later saw them in England. They were welcomed by their daughter Helen, whom they had not seen for twenty-seven years.

Mrs. Moffat felt a stranger in her home country. Her thoughts went wandering back to her real home, to her sunbathed stoop, so different from foggy English streets, to her child-people whom she knew and loved,-so much more loving and lovable than the white people. Out there she had been mother to them all; here she was a strange old woman! She could not bear it long, and within six months caught cold and, after a short illness, passed away. The poor old hero, Moffat, led a wandering life for two and a half years in Great Britain, speaking in many meetings, telling of his experiences, charming young and old with his magnificent powers of description.

During the last seven years of his life he lived in a little house in Brixton, one of the suburbs of London, and there he died on Thursday evening, the 9 th of August, I 883 .

The year before his death, Cetewayo, King of the Zulus, was in England, and Moffat (now eighty-seven years old) determined to go and see him. He could not speak Zulu, but among the followers of Cetewayo 
was a man who had been with the son of Mosilikatse during his exile in Zululand, and who spoke Sechuana. When Moffat, his great old rugged body bent, his white beard flowing to his waist, stepped into the circle of the black men, they rose from the ground where they had been sitting, they raised their right hands above their heads and shook them (the salutation of respect).

"Welcome, great father!" (so the interpreter translated) "Welcome among your children." Cetewayo himself stepped forward to greet Moffat and with shaking voice said, "I see this day what my eyes never expected to behold-Moshete." 

CHAPTER VI (Continued)

The Pathfinder-David Livingstone 


\section{DAVID LIVINGSTONE}

1813 (March 19th) Born at Blantyre, Scotland.

1842 At Kuruman in South Africa (600 miles from Cape Town).

1843 At Mabotsa.

185 I Left Mabotsa.

1855 (November) Discovered the Victoria Falls.

1856 (August I2th) Left Quilimane for Mauritius, and his first furlough.

I 858 (March roth) Led Zambesi River Expedition.

I 859 Discovered and named Lake Nyassa.

I86I (April 27th) Mrs. Livingstone died at Shupanga.

I864 (April 30th) Arrived at Zanzibar, and thence took Lady Nyassa to Bombay.

1865 (April) Began third expedition to discover sources of the Nile.

1866 (March 19th) Left Zanzibar.

1867 (July 18th) Discovered and named Lake Bangweolo.

1869 (March 14th) At Ujiji on Lake Tanganika.

$187 \mathrm{I}$ (November Ioth) Stanley at Ujiji.

1872 (August 23rd) Left Unyanyembe to explore the Lualaba, which he thought was the Nile, but which Stanley afterwards found to be the Congo.

I873 (May Ist) Died at Chitambo's village, Ulala. 


\section{CHAPTER VI (Continued)}

"MANY a morning have I stood on the porch of my house, and looking northward, have seen the smoke arise from villages that have never heard of Jesus Christ. I have seen, at different times, the smoke of a thousand villages-villages whose people are without Christ, without God, and without hope in the world. The smoke of a thousand villages The smoke of a thousand villages." Thus spoke the South African pioneer, Robert Moffat. The meeting closed, and out of the door of the hall went a young man-a young medical student, David Livingstone; but with him went the words of Moffat-"The smoke of a thousand villages whose people have never heard

The smoke of a thousand villages."

He could not sleep that night. The lure of Africa had caught him-the lure of a work worth doing, the biggest work that a young man who strives to follow Christ can attempt. "The smoke of a thousand villages." Moffat's words sang on in his ears. Why should not he become the spiritual father of nations of the future? Dimly Livingstone saw Africa's millions waiting in the shadows-saw the smoke arising from their camp and hearth fires- "The smoke of a thousand villages."

He left England, and arrived unheralded in Africa -he who had few gifts but will-power to make his 


\section{I74 AFRICAN HEROES AND HEROINES}

own future and the success of his life. How little did the Committee of the London Missionary Society realize when they accepted this young man as a missionary, that after forty-three years he would be buried in Westminster Abbey, and that his tomb in the Abbey would be visited by more people from the ends of the earth than any other tomb in that mausoleum of the mighty!

Seven thousand miles away from where we saw him last, young David Livingstone stands on the stoop of his mission-house at Mabotsa. He has been at this mission post for eight years. Northward stretches the plain, up from the valley where he has lived and tasted the fruits and failures of a young missionary's married life. Northward stretches the plain into the great unknown, beckoning him, calling to him in the night watches. Up yonder lies his life's work, the work that shall make him great, the work worth doing, and worth dying for. Yonder must lie the gold mines of Sofala, yonder the Mountains of the Moon, yonder the weird mysteries of rivers, lakes, and virgin forests, yonder the smoking fires of unknown cities, towns and villages-beckoning the pathfinder of the missionaries of the Christ-faith!

"Mary, will you go with me to the north land? I want to open a way into the heart of Africa for the gospel ?"

And Mary answered, "Whither thou goest there also will I go."

There are some whose lives, like painters' pictures, show delicate coloring and a smooth surface; and there 
are others whose lives are like pictures in which the paint is laid on heavily with the palette-knife-brilliant high lights and inky shadows. Livingstone's life was one of the latter. Great were his troubles: dark were the shadows of sorrow and pain, of trouble and distress, but bright was the light in which anon he basked-the praise of his fellow-men, and the knowledge that he was privileged to initiate great enterprises that would live through the ages to come.

David Livingstone was not a genius; that is to say, he had no extraordinary gift; he had, though, the gift without which no genius becomes great-the ability to do hard work with painstaking persistence. He was no giant physically; mentally and spiritually he was but a good average Christian man. That is to say, work similar to his would be possible for any young Christian with fair abilities, but-David Livingstone worked. When as a boy he stood behind the weaver's loom, it was not enough for him to do his weaving faithfully. He realized that his mind was capable of more work while he was watching the threads, and he invested in a Latin grammar.

What a stimulus the example of David Livingstone has been to many a youth who has been told by missionary boards and officials to go and do likewise! At least three times the writer has put the example of David Livingstone before young men who came to consult him as to how to fit themselves for foreign missions when they had not the money to go to college. "Save the money you earn. Buy the books you need, and do as David Livingstone did-study." One of 


\section{I76 AFRICAN HEROES AND HEROINES}

these men is to-day a professor of engineering in one of the Chinese universities; another is a medical man on the West Coast of Africa in the work in which Mary Slessor did such splendid service; and the third is in charge of the Lucy Memorial Freed Slaves Home in Northern Nigeria.

Livingstone loved nature, but found no time for botany or zoölogy. There were greater things to be done in Africa in his day than collecting birds and butterflies. Before the microcosmos in Africa could be dealt with, the macrocosmos, the outlines, the outstanding landmarks of the interior of the continent, had to be investigated. To do this satisfactorily, survey instruments were needed, and as in the days of his boyhood he bought the Latin grammar with his savings, so now he invested in a sextant, a magnetic compass, an artificial horizon, and barometers. Diligently he perfected himself in the use of these instruments.

When travelling on steamers to and from Africa he always availed himself of the opportunity of comparing notes with ship's officers when, at noonday, as is the custom, they had to "shoot the sun" (take place observations).

It has been the writer's privilege to handle David Livingstone's scientific instruments, and though they are somewhat out-of-date, they are to this day quite good enough to fix any geographical position. On his journeys in South Central Africa he covered 28,000 miles. He crossed Africa from east to west, and travelled from the Cape to the sources of the Congo.

For many months the doctor had heard native vis- 
itors speak with awe of the Mosi-oa-tunya (Smoke that Thunders). In November, I 855 , he set out to find the "Smoke that Thunders"- - to find this volcano and put it on the map. Enough was known already of the heart of Africa, through reports that were brought to the East Coast and to Egypt, to make it certain that there must be a great volcanic region beyond the unexplored parts of the interior. The coast line had been mapped, and some of the hinterland investigated by Mungo Park, Barth and Brown, by Gordon Cumming, Krapf and Rebman.

One morning at daybreak, looking out of his tent, Livingstone saw one of the strangest phenomena a white man has ever seen. Under a cloudless sky, on the northern horizon, there appeared a rainbow. Had any one ever seen a rainbow without clouds to bring the rain! Hurrying on the boys with the packing in order to get on the march, he travelled towards this strange sign, turning over in his mind the probable cause of such an incredible sight. The day wore on and still the rainbow stayed, growing brighter and clearer the nearer our missionary approached. Through the hot atmosphere of the noon-day, a distant thunder sounded on his ear-thunder without lightning, thunder without clouds. Then he noticed above the tree-tops a smoke. Had he been a Greek of olden days, in awe he would have hesitated to approach the workshop of Hephaestus. Louder the thunder roared. Livingstone was not superstitious or credulous. Long ago he had fought out his battle with fear. Some of his guides, who had shown him the way thus far, stepped 


\section{I78 AFRICAN HEROES AND HEROINES}

up to him. "Kind Doctor, we dare go no further. The Great Spirit, who dwells yonder, would destroy us." So camp was formed, and alone the white pioneer set out to investigate. The forest became more dense; then, to his astonishment, rain began to fall out of a clear sky. Luxuriant vegetation surrounded him in the rain forest. Over a fallen tree he climbed, then forged his way through dense liana creeper vines and - stood on the brink of the greatest waterfall in the world. He had sought for a volcano, and he found something far more wonderful. One of the two greatest sights in the world (the other being the Grand Canyon) lay before him. There are many beautiful waterfalls. There are two or three in the world that are awe-inspiring; but there is one, the view of which is overwhelming. One of the five great rivers of Africa, the Zambesi, forming a vast lagoon edged in on the east by a number of islands, flings itself between these islands into a chasm. This chasm is part of the rift valley of Africa, that begins in Abyssinia and ends in Cape Colony.

For a while the great man stood in silent wonder. It was hard to tear himself away; but physical weakness after a long day's march made itself felt to a mind awhirl with overwhelming impressions. Resolutely he turned his back upon the falls, and retraced his footsteps to the camp, and to his anxiously waiting people.

Next morning, armed with ropes and scientific instruments, he set out again to try and find the width and depth of the falls, which he had determined to 
name after the queen of his country, the "Victoria Falls." From island to island he stretched his line, crossing in a dug-out canoe, which had been secured from a village some distance up the river. When adding up the figures and finding that the width of the river at the falls was over a mile and the depth of the fall four hundred feet, he noted in his diary-

"It is impossible for me to send such figures home in my report to the Royal Geographical Society. I should be called 'a stranger to the truth', and being a missionary I cannot afford to have this said of me."

So, to be conservative, he divided his figures by half, giving the width of the fall in his report as over half a mile, and the depth as over two hundred feet,and with these figures the Zambesi falls were the greatest in the world.

When the writer visited Rhodesia six years ago, and found his way to the Victoria Falls, he was rowed across to Livingstone Island, and sitting on a projected rock within a few feet of the rushing water, with pencil and note-book sought for words to describe the indescribable.

The snow fog rises from the boiling caldron,

Eternal thunder roars from roaring deep,

Unutterable abandonment leaps gigantically solemn into

Nature's groaning abyss.

Black basalt, scintillating steam, and foam, and fury,

Show, in cyclopean chaos one of Pluto's workshops; 


\section{I8O AFRICAN HEROES AND HEROINES}

While silver sunshine wreathes round the crags, the rainbowLife-giving water wed to ghastly death.

Above the falls a wide river, innumerable isles, hidden rocky shallows, pleasant bays, profound pools, herds of hippo, flocks of waterfowl, shoals of fishes, swift canoes, a superabundance of happy life, seem unconsciously to approach the knife-edged barrier to the brink. One can go quite close to the edge of the chasm, and all around it. The only dangerous place is the Devil's Cataract; at all other places the suction of the falling river is but little felt. The stream is two thousand yards wide at the falls, and this whole vast volume of water goes up in steam when, in the ghastly leap of four hundred feet, the torrents dash themselves against the gloomy cliffs. The river has disappeared, but, unseen from above, the waters gather themselves together again, and from the Boiling Pot, past the Palm Grove under the Rain forest, the deep swelling black waves slowly roll under the railway bridge, until, forty miles beyond the gorge, they emerge into the pleasant plains of the new wide valley.

The week before I visited the falls, two boys had quarreled in a canoe, when the current of the Devil's Cataract had caught hold of it. One jumped, and swimming and scrambling over the rocks, saved himself, but the other was carried over the edge and never seen again. When emerging from the Palm Grove close to the Boiling Pot, I came upon the last remnant of that boat-a small piece of its backbone, the center of its keel. 
Words utterly fail to describe the unforgettable glory, the awesome sight, the mist clouds, the wild unbridled fury of the frothy falls, the river rainbow, the Aurora Victorialis.

"Master, I am coming!" cried Mebaline, the native teacher, as Livingstone lay under a lion, his arm bitten through, and in the jaws of the beast. But both barrels of Mebaline's gun missed fire, and as he was only ten yards away, the lion left our fallen hero, jumped on the native, threw him, and bit him through the side. Then another native, whose life David Livingstone had previously saved, came to the rescue. He also was attacked and bitten through the shoulder, and then-the lion died. All this was enacted near Livingstone's station in much less time than it takes to tell.

Lions had become very troublsome, one of them killing nine sheep opposite the missionary's house in broad daylight. The Bechuanas had tried to deal with them but were unable to kill them, and, like his namesake of old, the new David had to become a lion killer and deal with the marauders. He had gone after them, shot one sitting on a rock behind a bush, and fired both barrels into him. Both shots took effect, but did not put an instantaneous end to the lion's life, and there followed the incident above related. The bone of Livingstone's arm was splintered, and the eleven tooth-marks never disappeared, though the wound healed. The arm never was as strong again as the other, and when his body was brought home to Eng- 


\section{82 AFRICAN HEROES AND HEROINES}

land many years later, it was recognized by the broken bone and the tooth-marks left by the lion.

During the winter of $1860-6$ I, Livingstone had some of his most terrible experiences in Africa. On his return from the discovery of Lake Nyassa, he found that Mr. and Mrs. Hillmore (whom he had left in the Makololo country) had died of fever, and the natives of that district had lost all interest in the mission. Discouraged, Livingstone returned to Lake Nyassa, built a boat, and for six months sailed the waters of the lake, making a chart of it. Then a storm wrecked his vessel, and Livingstone lost nearly all he had with him. He had to return to the Rovula River early in $186 \mathrm{I}$, where the Pioneer had been sent with new supplies for him. Fever broke out among his people, and the lack of proper medicines had a good deal to do with the death of Mrs. Livingstone.

It was the $27^{\text {th }}$ day of April, I86I, at Shupanga. The deep hanging branches of a mighty baobob tree shaded a procession that approached an open grave. Mary Moffat, the wife of David who was named Livingstone, had ended her earthly journeyings, and was to be buried far from home, in God's wilderness in Central Africa. Reverently the boys lowered the body into the grave, while the great pioneer, his lips tightly closed, his hands over his eyes, murmured to himself, "The Lord gave: the Lord hath taken away. Blessed be the name of the Lord!" "

"Oh, Mary, why did I lead you to this Valley of the Shadow! I would love to lie down here would our Father but take me. Mary, my Mary, wait for me 
over there!" A lonely man left the closed grave, but a man determined to use the days of his life to the full, and, should God permit him, carry through the plan of his life's work, and open the lands of Africa wide for the message of the Son of God-the Great Pioneer through the Valley of the Shadow to the lands where there is no shadow and no night.

It was a sultry summer afternoon when at Nyangwe on the Lualaba, in the market of the village, some fifteen hundred women, besides the men, had come together from across the river to trade and traffic with the foreign people. An Arab chieftain's caravan had settled down and formed camp, and David Livingstone after many weeks of travel, was resting now here on the Upper Congo. The river which the natives call the "Lualaba" was, though unknown to Livingstone, the head branch of the Zaire, which Stanley later called the Congo.

Through the hot air of the afternoon a rifle shot rang out, then other shots, a fusilade, and down the dusty path came flying women, screaming, and after them the Arabs, firing as they ran, shooting the men down right and left. The Arabs explained that some little squabble over barter had caused the trouble, but Livingstone, who knew the Arabs, knew also full well that the attack had been premeditated and prepared for. Into canoes and dug-outs the natives scrambled. Some of the boats capsized with their frightened freight, and into this mass of struggling humanity, the Arabs fired steadily. Some of the natives tried to swim the river, while the Moslems laughingly shot at 


\section{I84 AFRICAN HEROES AND HEROINES}

them. Those that were not killed by bullets were swept away by the strong current, and hardly any of them were left alive.

It was when writing of this incident that, in his notes, the doctor said, "I felt like pistolling those Arabs, but the dead I could not bring to life again. What good should I have done? Indeed I should have sacrificed my followers, and to do this I had no right." It was then also that he wrote, "May God bless every one, American, British, or Turk, who will help to heal this open sore of the world."

Next morning as he started eastward he counted seventeen villages in flames. This was the only period in his life in which he was fired upon by the natives, being mistaken for a slave-raider. It was indeed shortly after he had left the Lualaba, that, when passing through the country of the Manjuema, he was for five hours, exposed to shots by archers and by spearmen. One spear grazed his back, another was hurled into the ground close to his feet. Then a great tree crashed down in front of him, almost striking him to the earth. Three times, on that day, he narrowly escaped death.

Livingstone had been honored by great societies, had been lauded by the press, yet his pocket-book was empty when in April, I 864, he arrived at Zanzibar. All he possessed was a little launch called Lady Nyassa, and for the Lady Nyassa there was no market in Zanzibar. He needed money and needed it badly; then, accompanied by seven of his faithful natives and two Europeans, he set sail for Bombay across the Indian 
Ocean, in the hope that he might there he able to realize, if not as much as the boat had cost him, at least enough to pay what he owed his followers, his other debts, and his passage home. He was no sailor, his native boys had never been to sea before, and his boat was little more than a cockle-shell on the stormy ocean he proposed to navigate; but he had been in tight places before. In a letter written on February $23 \mathrm{rd}$, I 859, to Miss Whately (the daughter of the Archbishop of Dublin), from the Upper Zambesi, he says—"We were unfortunate enough to be misled in the vessel we now use, and rejected another which we now find would have suited us admirably. The naval officer who misled us suffered from sea-sickness and irritability so much that he resigned when he imagined we could not help ourselves. But I took the task of navigating on myself, and have conducted the steamer over I,600 miles, though as far as my likings go I would as soon drive a cab in November fogs in London as be 'skipper' in this hot sun-but I shall go through with it as a duty." The word "duty" is a favorite word of David Livingstone's, and appears again and again in his letters. In a letter written on the 9 th of September, I 857 , he closed an eight-page epistle by saying, "It is in the way of duty, and we shall try not to be craven-hearted." The word "duty" is a good word and effective. Nelson used it. In the Battle of Trafalgar, when he finally established the British dominance on the sea and safeguarded the British realm and its dominions, he signaled to his captains- "England expects every man to do his duty." 


\section{I86 AFRICAN HEROES AND HEROINES}

Livingstone's native followers had served him well. He owed them payment and it was his duty to meet his liabilities: so across the wide expanse of tropical seas he steered his little vessel, to sell her and then pay his debts. His own country had treated him shabbily, as twenty-five years later Gordon was treated at Khartum, and though Livingstone had been appointed British consul and representative of the greatest empire, and though he had been lauded to the skies, not enough was given to him to pay his few native boys. It was an American who, on Livingstone's last journey in Africa, sent him supplies-and when our hero died he was in abject poverty. Let him perish of neglect, and then bury him in Westminster Abbey! Let Gordon first be murdered (when so easily he might have been saved) and then build him a mausoleum in St. Paul's cathedral! To this day the British Government is afraid to show the correspondence of David Livingstone that is hidden in the Government archives. One wonders why. Indeed, one does not need to wonder why! The governments of the world are not over generous in their payment of the men whom God has chosen to do the great work in this world of His, whether their names be Columbus, Raleigh, Holland, or Livingstone. At the hundredth anniversary celebration of David Livingstone's birth, in the Albert Hall in London, under the chairmanship of the Archbishop of Canterbury, Sir Harry Johnston in his address bitterly complained that the British Government denied him access to the letters of David Livingstone.

At a time of life when many a man looks robust 
and vigorous, preparing for maybe another twenty years of work, our hero was a bent old man, though only fifty-eight. Surging sorrows had gone over his gray head. Deep lines and grooves were graven into his strong face. Misunderstandings and malicious slanders from those he had thought his fastest friends had, if not embittered, saddened him. He might look back upon a record of achievements in the service of God and of his fellow-men equaled by few. This was encouraging. But, on the other hand, his experiences with the slave-raiders (and their work still continued), with the Government, yea, and with the missionary societies, were, to say the least of it, discouraging.

$\mathrm{He}$ was at Ujiji on the north eastern shore of Lake Tanganika. His food and medical supplies were exhausted. Financially he was in straits, and his arm (broken by the teeth of the lion) gave him a good deal of trouble. His neighbors were Arab slave-traders. They were friendly enough. They respected this brave man, though they knew how he disapproved of their business operations.

Brooding alone, he sat under a grass mat thrown over rough wooden posts to protect him from the sun. One of his faithful native boys ran up to him.

"Doctor, many people are coming down the path, many-many !"

Slowly Livingstone raised his eyes from the ground, where he had been drawing figures on the sand, in time to see around the corner of yonder field of Kaffir corn, a flag-the first of its kind he had seen in Africa. It was not the "Four Color" of the Orange and the 


\section{88 AFRICAN HEROES AND HEROINES}

Transvaal, nor the Portuguese, nor the Union Jack. It was a flag that now, for the first time, appeared in the interior of the Dark Continent-a flag that only seven years before had for ever settled the liberty of Africa's black children in the United States of North America-

"The Stars and Stripes."

What did they want with that flag here in Africa among the slave-raiders? Was it some quixotic expedition from afar to proclaim liberty to the slaves of Africa? Laboriously he rose, stood on his feet, and with his left hand shading his eyes, looked at the flag that was approaching. Now he could see the boy who carried it and then-a white man in a khaki cap-and then-a whole host of carriers-crowds of them! Nearer they came. The white man saw him, and with outstretched hands marched up.

"Dr. Livingstone, I presume? My name is Stanley." And they shook hands.

"Well?" said Livingstone.

"I have been sent by Mr. Bennett of the New York Herald to find you, and to bring you new supplies, and, if you like, escort you to the coast."

"You've come from America to help me?"

"No, I have come from Paris. I was in France, and received instructions to go and find you."

"From Paris? But why?"

Forgotten by his missionary friends, and by his Government, alone and almost helpless, the Doctor needed time to understand the meaning of the surprising, sudden, unexpected succor. But when at last he under- 
stood, he turned away abruptly, went into his hut to hide his deep emotions, and thanked God for answering his prayers. He realized that his life's work was not for nought: he was remembered and thought much of throughout the world-so much so, that from a land he had never seen, from a man he did not know, and through a man he had never heard of, supplies had come that might enable him-perhaps-to accomplish the work he had still in mind to do, namely to find the sources of the Nile.

One wonders sometimes whether, when he died there in far Ulala less than two years later, it was not with a deep sigh of relief, believing that he had found what he had sought, the Lualaba's source at Bangweolo (and the Lualaba was, in his mind of course, the Nile).

For days the two great pioneers, the "Dr. David" and the one who later was known as "Sir Henry," conferred and planned. It was then that Stanley, through the influence of Livingstone, determined to give his life to the amelioration of the people in Darkest Africa.

This is Livingstone's hundredth birthday (March the I9th, I913), and in Westminster Abbey, led by Bishop Riley, the Dean, are gathered the delegates of the great missionary and scientific organizations with which our hero had been connected during his life time, or that had grown out of his life work. This circle, though it may be small, is one of the most remarkable gatherings that the ancient abbey has ever seen. Presbyterians and Plymouth Brethren, Methodists and Baptists, Congregationalists and Friends, High and Low Church of England, men of little faith in God, 


\section{I90 AFRICAN HEROES AND HEROINES}

and some of less, men of much faith in God and some of more, have come to honor the memory of a man who was a Christian. ${ }^{1}$

Slowly and silently the procession moves from the chancel to the center of the Abbey. A thousand years of Christian worship look down upon a unique service. Stately statues stand around; fluted columns soar upward to the domed arches of the lofty roof; battle flags, bronze tablets, marble monuments of illustrious leaders of the minds of men are around us. Our feet tread on the tombstones of the nobles of the nation. We move in an atmosphere of mighty memories.

The procession halts before an unadorned flat slab of stone-the grave of the greatest Britain of the last century.

When they buried him here the poet of the merry paper, Punch, left his levity and wrote:

"Open the Abbey doors and bear him in

To sleep with king and statesman, chief and sage,-

The missionary, born of weaver kin,

But great by work that brooks no lower wage."

$*$

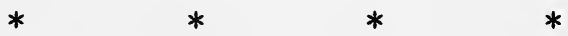

*

"Let marble crumble. Here lies Living-STONE."

They brought him here after long wanderings in the wilderness to rest among the great ones of his race-

David Livingstone-the prince of missionaries, the pioneer, the modern pathfinder in the Dark Continent,

${ }^{1}$ It was the privilege of the writer to arrange this memorial service with Bishop Riley. 
a philanthropist living beyond the limits of the little island soil on which he was born. His mother-country and his fatherland were God's own world, and those who needed him most he served most, not counting his life dear unto himself, but freely spending it that he might lead the dark-skinned children of the Dark Continent to the light-the Light of Life.

From the lips of the Bishop come the ancient prayers of the Church. A few minutes, and the Service is drawing to a close, when the Dean introduces an innovation. "Let us now," her says, "in silence think of the work which the man whose earthly remains lie here began, and left for us to carry on. Let us seek from God the strength and wisdom needed to carry through this work until the tribes of Africa have found their way into the light of our Lord Jesus Christ."

There is silence-a silence that can be felt. There is spiritual communion of souls ready for service and sacrifice, and as the rays of sunlight filtering through stained-glass windows play with the flowers placed there before us, in many a heart takes place a solemn sacrament of consecration.

"We will see to it that the door he has opened to the heart of Africa shall not be closed. We will see to it that the message he carried to the Children of the Shadows shall be taken further until all have heard. We will see to it that the outstretched hands of Ethiopia shall be linked with the outstretched hands of the Son of God."

Then came the Benediction. 


\section{I92 AFRICAN HEROES AND HEROINES}

Inscription on the tomb of David Livingstone in Westminster Abbey:

\section{BROUGHT BY FAITHFUL HANDS}

OVER LAND AND SEA

HERE RESTS

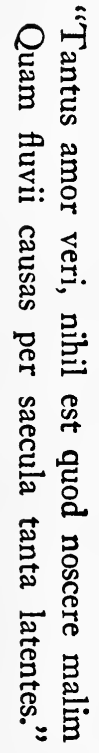

DAVID LIVINGSTONE

MISSIONARY

TRAVELLER

PHILANTHROPIST

BORN MARCH igth, I813

At Blantyre, Lanarkshire

DIED MAY I, I873

At Chitambo's village, Ulala

For 30 years his life was spent in an unwearied effort

To evangelize the native races

To explore the undiscovered secrets

To abolish the desolating slave trade

OF CENTRAL AFRICA

where with his last words he wrote

"All I can add in my solitude is

May Heaven's rich blessing come down

On every one, American, English or Turk

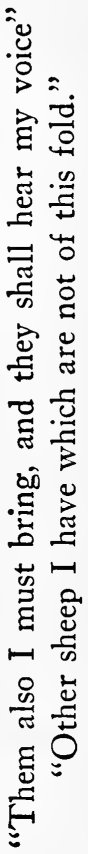
who will help to heal

This open sore of the world." 


\section{APPENDICES}

A. List of Christian Missionary Societies working in Africa.

B. Geographical Notes.

C. Bibliography of Biographies, Auto-Biographies and books written by the men and women with whom this book deals. 



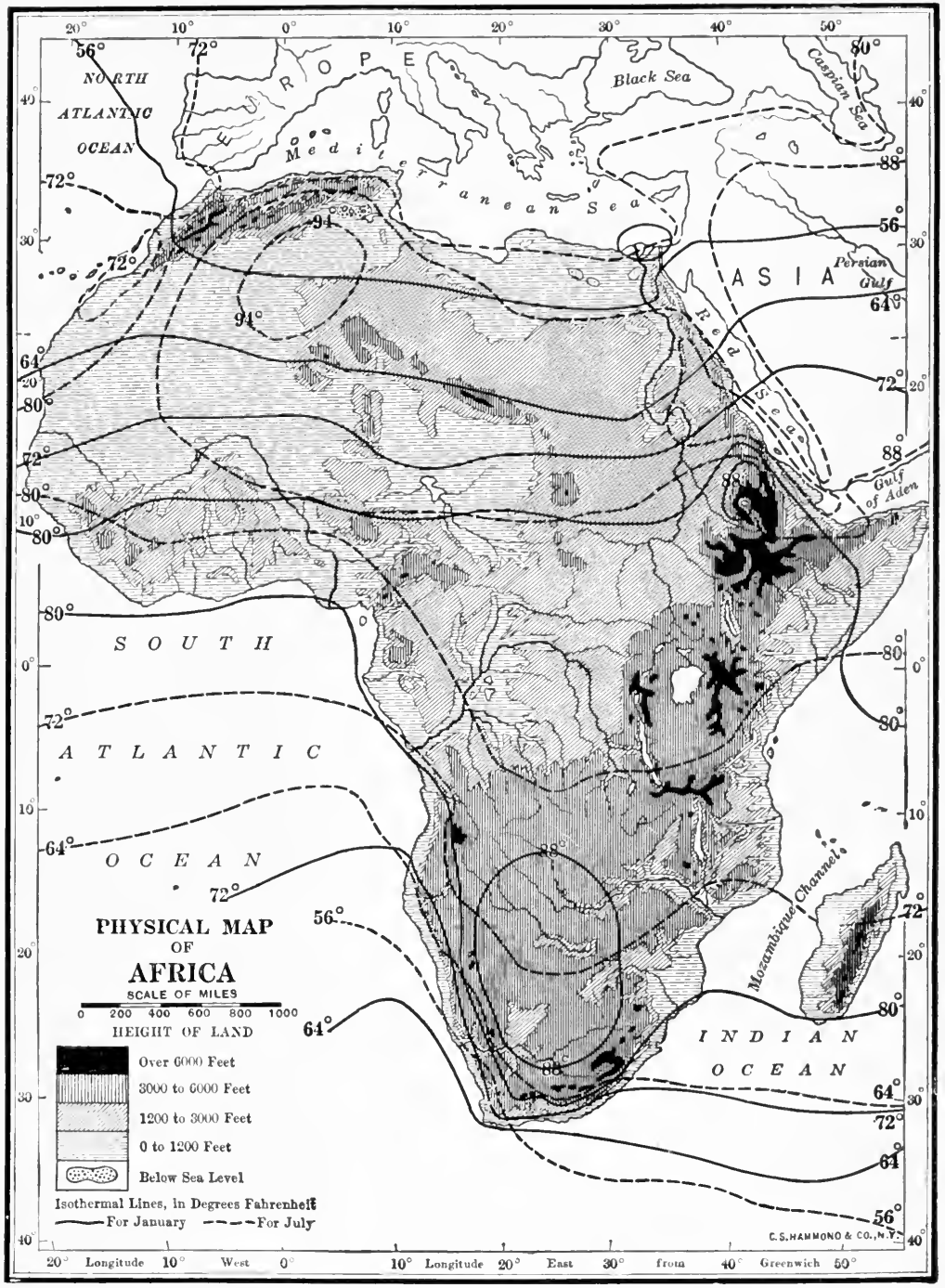




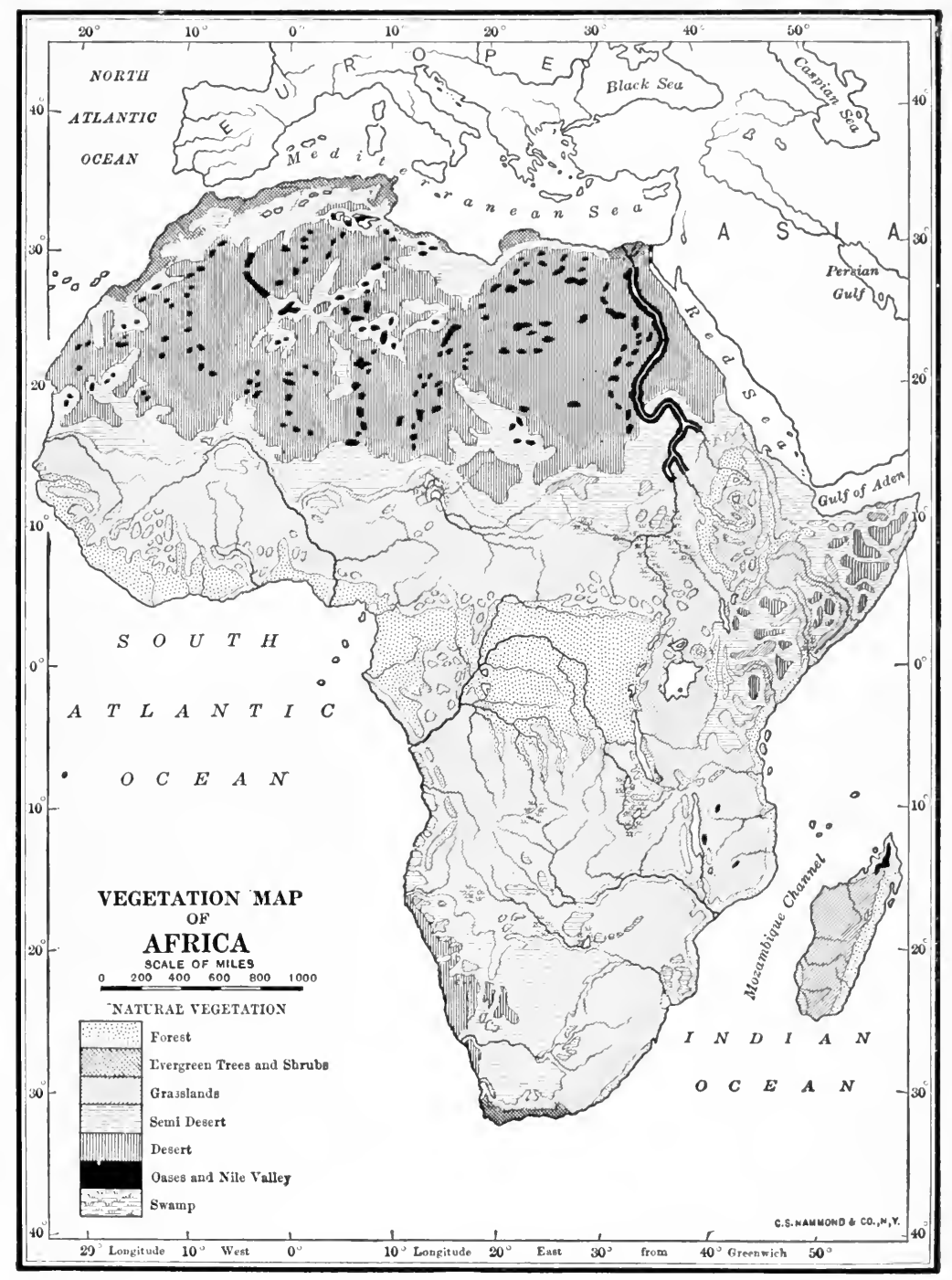




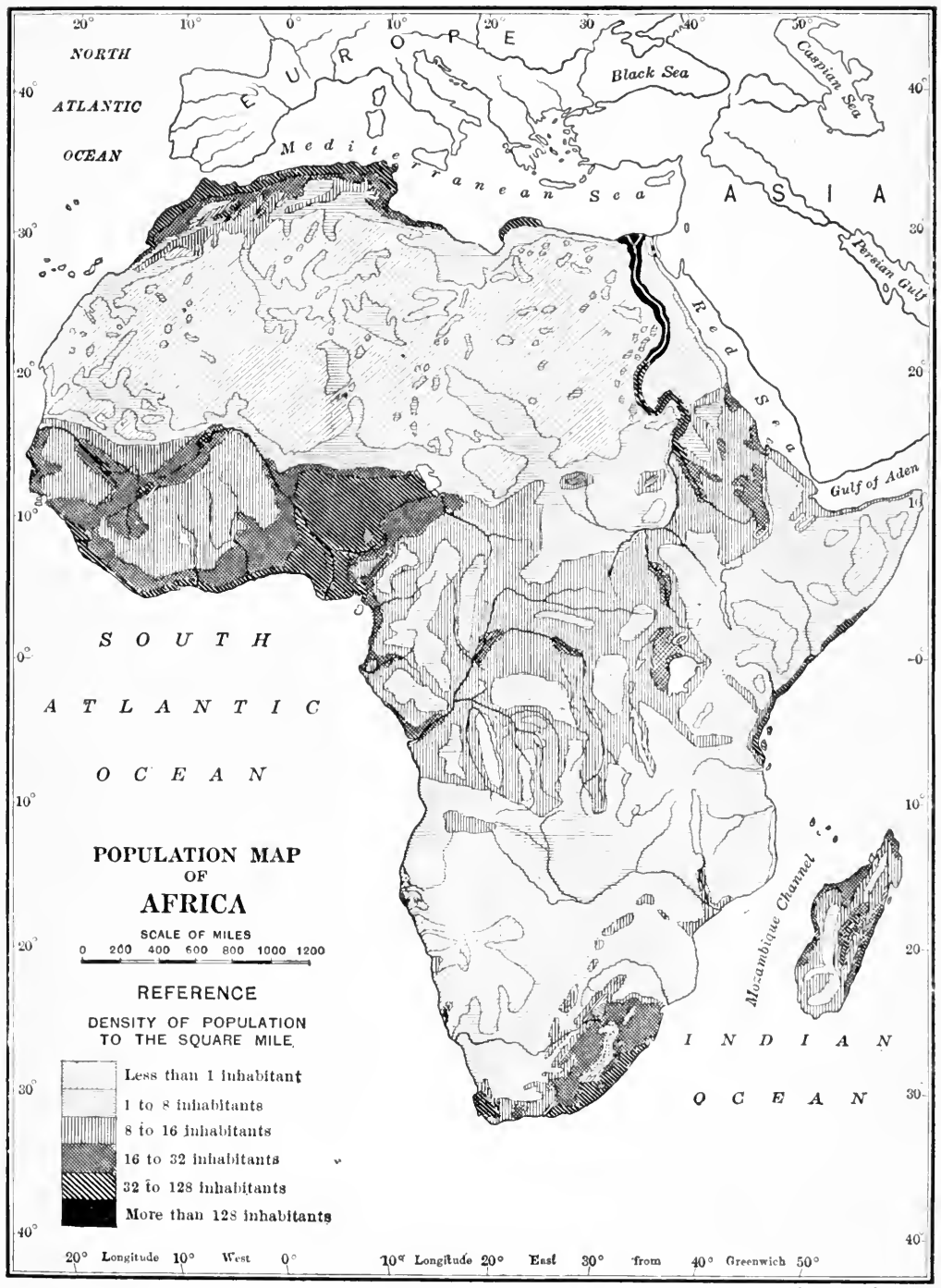

GS hayMOND \& CO.N,Y 
$\therefore+2$

策

as.....




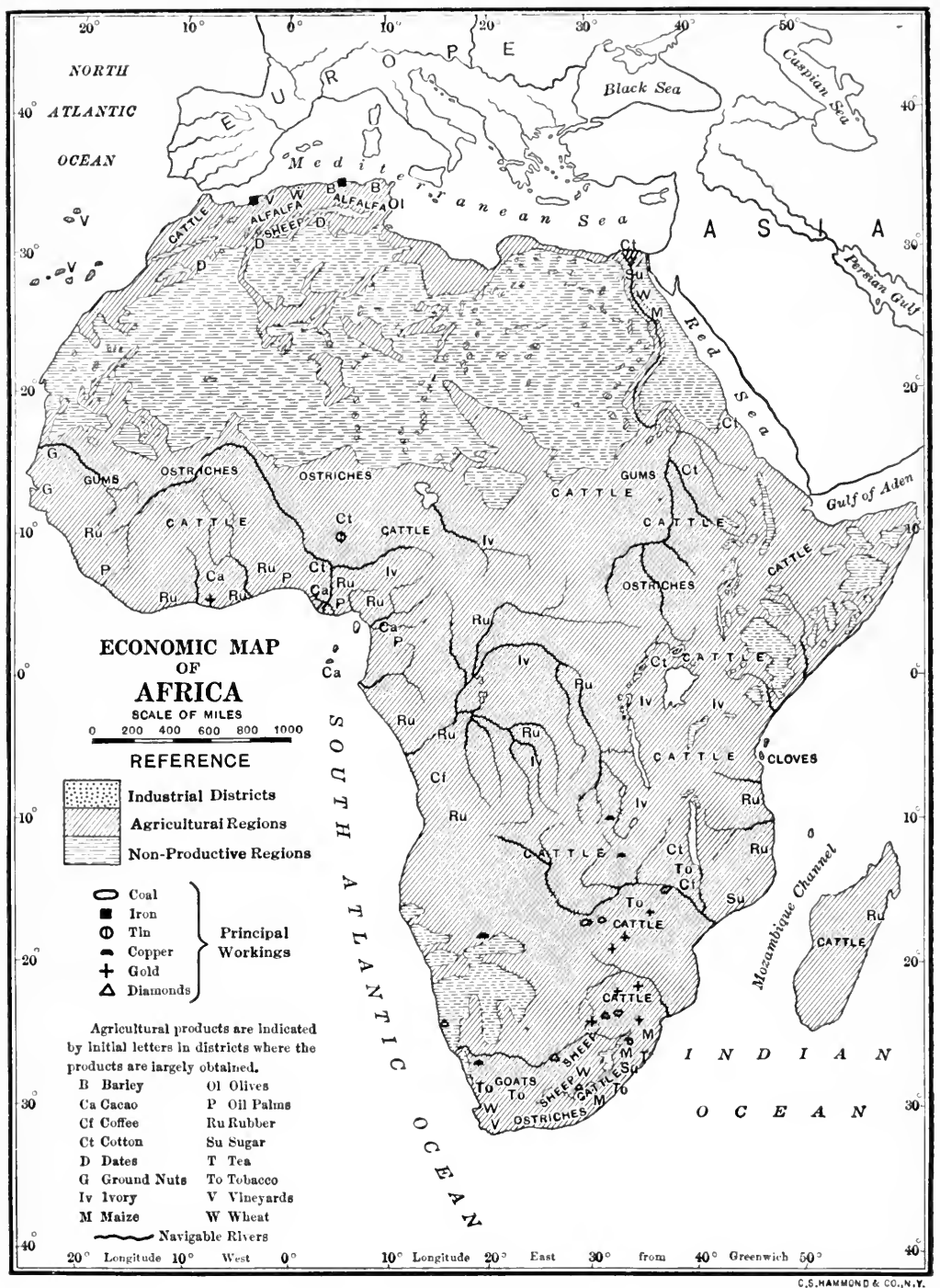


$-$ 


\section{APPENDIX A'}

The Christian Missionary Societies in Africa.

AMERICAN DENOMINATIONAL MISSIONARY SOCIETIES AT WORK IN AFRICA

(I) ABCFM..American Board of Commissioners for Foreign Missions.

(2) ABF..American Baptist Foreign Missionary Society.

(3) AFFM...American Friends Board of Foreign Missions.

(4) AME..Home and Foreign Missionary Society of the African Methodist Episcopal Church.

(5) AMEZ.. Missionary Society of the African Methodist Episcopal Zion Church.

(6) BC..Foreign Mission Board of the Brethren in Christ of the U.S. A. and Canada.

(7) ELGS. . Board of Foreign Missions of the General Synod of the Evangelical Lutheran Church of the U. S. A.

(8) FCMS. . Foreign Christian Missionary Society.

(9) FMA.. General Missionary Board of the Free Methodist Church of North America. ( Io) MEFB..Board of Foreign Missions of the Methodist Episcopal Church. 


\section{I96 AFRICAN HEROES AND HEROINES}

(I I) MES..Board of Foreign Missions of the Methodist Episcopal Church South.

( 12) MGC.. Board of Foreign Missions of the General Conference of the Mennonites of North America.

(13) NBC..Foreign Mission Board of the National Baptist Convention.

(14) PE..Domestic and Foreign Missionary Society of the Protestant Episcopal Church in the U. S. A.

( 15$)$ PN..Board of Foreign Missions of the Presbyterian Church in the U. S. A.

(16) PS. .Executive Committee of Foreign Missions of the Presbyterian Church in the U. S. A.

(17) SBC..Foreign Mission Board of the Southern Baptist Convention.

( 18 ) UB... Foreign Missionary Society of the United Brethren in Christ.

(20) UE. . Home and Foreign Missionary Society of the United Evangelical Church.

(2 I) UP...Board of Foreign Missions of the United Presbyterian Church of North America.

(22) WMCA...Missionary Society of the Wesleyan Methodist Connexion of America.

BRITISH DENOMINATIONAL MISSIONARY SOCIETIES WORKING IN AFRICA.

( I) BIMS. . Baptist Industrial Mission of Scotland. (2) BMS. . Baptist Foreign Missionary Society. (3) CMS. . Church Missionary Society. 
(4) CSFM.. Church of Scotland Foreign Missionary Society.

(5) CSI..Church of Scotland Committee for the Conversion of the Jews.

(6) FCS...Free Church of Scotland Foreign Missions.

(7) FFMA..Friends Foreign Missionary Association.

(8) PB...Plymouth Brethren Mission.

(9) PMMS . Primitive Methodist Foreign Missionary Society.

( I o) SLM..Countess of Huntingdon's Connexion Sierra Leone Mission.

( I I) SPCK. . Society for the Propagation of Christian Knowledge.

( I 2) SPG. . Society for the Propagation of the Gospel in Foreign Parts.

( 3 ) UFS. . United Free Church of Scotland Foreign Missionary Society.

( I4) UM...Universities' Mission.

( I 5) UMC..United Methodist Church Missionary Society.

( 6 ) WMS. . Wesleyan Methodist Foreign Missionary Society.

PROTESTANT EUROPEAN CONTINENTAL AND SOUTH AFRICAN MISSIONARY SOCIETIES WORKING IN AFRICA.

( I) B..Basle Mission (Swiss).

(2) Be..Berlin Mission (German). 


\section{I98 AFRICAN HEROES AND HEROINES}

(3) $\mathrm{Br}$..Breklum Mission (German).

(4) CUSA. . Congregational Union Church Aid and Missionary Society of South Africa.

(5) DOA. Evangelical Missionary Society for German East Africa (German).

(6) DRCSA..General Mission Committee of the Dutch Reformed Church of South Africa.

(7) EFS. Evangelical National Society in Sweden (Swedish).

(8) FBS...Independent Baptists (Swedish).

(9) FMS. . Finnish Missionary Society (Finnish).

( Io) GM..Gossner Missionary Society (German).

( I I) HM. . Hermansburg Mission (German).

( I 2) KD.. Kaiserwerth Deaconesses (German).

( 13) Lp.. Leipzig Mission (German).

(I4) MGB.. Mission of the German Baptists (German).

( I 5) MHLF..Hanover Missionary Society (German).

( 16) MPH..Swiss Philafrican Mission (Swiss).

(I 7) MR.. Mission Romande (Swiss).

(I 8) NM..Neukirchen Mission (German).

(19) NMF..Norwegian Mission Union (Norwegian).

(20) NMG..North German Missionary Society (German).

(2 I) NMS. . Norwegian Missionary Society (Norwegian).

(22) P..Paris Evangelical Missionary Society (French). 
(23) PCSA.. Native Missions Committee of the Presbyterian Church of South Africa.

(24) RM.. Rhenish Missionary Society (German).

(25) SABMS..South African Baptist Missionary Society (South Africa).

(26) SAF...South African Missionary SocietyMethodists (South Africa).

(27) SAMS. . Swedish Alliance Mission (Swedish). (28) SBM. . Swedish Baptist Foreign Missions Committee (Swedish).

(29) Sch.. Schreuder Mission (Norway).

(30) SMF..Swedish Missionary Society (Swedish). (3 I) SKM...Church Mission of Sweden (Swedish). (32) SPM...Sudan Pioneer Mission (German). (33) VUEE. . Union for the Propagation of the Gospel in Egypt (Dutch).

INTERDENOMINATIONAL AND INTERNATIONAL MISSIONS WORKING IN AFRICA

(I) AEM. Angola Evangelical Mission.

(2) AIM. .Africa Inland Mission.

(3) BFBS. British and Foreign Bible Society.

(4) CBM. . Congo Balolo Mission.

(5) CMA.. Christian and Missionary Alliance.

(6) EGM. Egypt General Mission.

(7) EM..Ethiopian Mission.

(8) HAM. . Heart of Africa Mission.

(9) LIS. . London Society for Promoting Christianity among the Jews.

( Iо) MIM. . Mandingo Industrial Mission. 


\section{AFRICAN HEROES AND HEROINES}

( I 2) MMJ.. Mildmay Mission to the Jews.

(13) Mor...Moravian Missionary Society.

(14) NAM. . North Africa Mission.

( 5 ) NIM.. Nyassa Industrial Mission.

( I6) NMP.. Nile Mission Press.

(I7) QIM.. Qua Iboe Mission.

(I8) SACIM...South African Compounds and Interior Mission.

(19) SAGM..South African General Mission.

(20) SIM. .Sudan Interior Mission.

(2 I) SMM. .Southern Morocco Mission.

(22) SUM. . Sudan United Mission.

(23) YMCA.. Young Men's Christian Association.

(24) ZIM. .Zambesi Industrial Mission.

\section{ROMAN CATHOLIC MISSIONS IN AFRICA}

( I) BM. . Benedictine Mission.

(2) CSSp. . Fathers of the Holy Spirit.

(3) CW... Clergy of the World.

(4) Fr...Franciscans.

(5), Kp. . Capuchins.

(6) LS. . Lyons Mission.

(7) Lz. . Lazarists.

(8) MH. . Mill Hill Mission.

(9) OC. . Oblates of the Immaculate Conception.

(io) OT..Oblates of Troyes.

( I I) $\mathrm{Pa}$.. Pallottin Mission.

(I 2) PB.. White Fathers (Pères Blancs).

(I3) PH..Priests of the Holy Heart. 


\section{APPENDICES}

(14) PT..Praemonstratenses of Tongerloo (Belgium).

( I 5 ) Sch. . Scheutveld Mission.

( I6) SJ.. Jesuits (Societas Jesu).

( I 7) SM...Steyl Mission.

( I8) $\mathrm{Tr} .$. Trappists.

(19) VS. . Verona Society.

Besides the missionary societies the following Christian organizations are at work in Africa:

I. The Cairo Christian University.

2. The Christian Student Movement.

3. The American Bible Society.

4. The Young Women's Christian Association.

5. The Christian Sailors' Home in Alexandria.

6. The South African Railway Mission.

7. The Lucy Memorial Freed Slaves' Home. 


\section{APPENDIX B}

\section{Geographical Notes}

A set of maps such as the following may teach us many things. They show the influence the orographical configuration of a country, the climatic conditions and the mineral wealth has upon the botanical and zoölogical products, as well as the distribution, physical development, and (to a certain extent) mental and moral attainments of man.

We notice from the physical map the rapids and cataracts shown by the four great African river systems not far from the coast line. These are, of course, caused by the escarpment where the great rivers leave the plateaux for the lowlands.

We have the greatest rainfall in Africa where the air currents from the sea during certain seasons strike mountainous regions such as the East African peaks, -Kenia, Kilimanjaro and Ruvenzori, the Cameroon Mountain in the West, and also the Hylæa Belt, that stretches across the continent.

The rainfall determines the hydrography, and rivers and lakes are the highroads of an undeveloped country.

Air currents and altitude have a great deal to do with the temperature. A study of the maps should show us the reasons why the highest summer and winter average temperatures are not found under the 
Equator, but in Abyssinia, in the northwest parts of the Sahara, and on the South African Karroo. Air heavily laden with moisture shows little variation of temperature between day and night, and between winter and summer. The West African coast and the Congo Basin have the greatest rainfall in Africa. We may therefore expect a climate with little change of temperature. The result of that is unhealthiness. The West African coast is called "The White Man's Grave." The greatest variations between winter and summer (we notice from the maps) are to be found in the deserts-and the desert climate is recognized as healthy. Embedded in the Sahara Desert are oases, and these oases (as is apparent from the economic map) are of considerable size, subterranean water supplies from the Nile and Lake Chad region, being the cause in the southern and eastern parts of the Great Desert, while the Tuat Oasis in the northwest receives the drainage from the Atlas Mountains.

Permit the writer to correct one or two misconceptions as to the Sahara. The plan to flood the great desert and make of it an inland lake is impossible of execution until we can persuade water to stay permanently on the hill-tops, for not more than one-hundredth part of the Sahara is below sea-level. An Arab on starting out on a journey into the interior from the North African coast, or the Nile valley, does not say, "Aruah fi Sahra" (I go into the desert-plain), but says, "Aruah fi Djebel" (I go into the mountains). Certain parts of the desert south of Algiers, and the northern parts of the Libyan Desert are below sea-level, but 


\section{AFRICAN HEROES AND HEROINES}

of the rest one-fifth is sandy dunes and four-fifths rocky plateau rising to 8,000 feet above the sea.

The second misconception is our idea of an oasis. The natural picture that comes to us when we speak of an oasis in the desert is of a well, a palm tree, and a nigger boy. Now an oasis may be one well and a few palm trees, but there are oases in the desert as large as some of the smaller states in the U.S. A. The oasis of Air or Asben is considerably larger than Rhode Island, and there are others as large as Delaware. An oasis is low-lying land surrounded by mountains, and watered by rivers and lakes. The population of the Sahara is variously estimated at from one to ten million.

The densest population we may expect near the arteries of trade and traffic-the great rivers and the coast. We find indeed that Lower Egypt, where coast and river combine, has the densest population of the continent. Next come the Niger Territories, then the North-West Coast, and South-East Africa. In the latter region the mineral wealth of the country has had an influence upon the growth of the population.

There is no time in these notes to go adequately into the distribution of Christian Missionary effort throughout the continent-the causes of the distribution and the effects of it. Suffice it to say that where adequate Christian missionary enterprise has been undertaken among the virile pagan tribes, the success has been very marked. 


\section{APPENDIX C}

A Bibliography of Biographies, Auto-Biographies and books written by the men and women with whom this book deals

\section{LIST OF BOOKS OF REFERENCE}

Perpetua........Tertullian, "De Anima."

Augustine, "Sermons 280, 283, and 294."

Cahina..........Irving, Washington, "Mahomet and his Successors."

Condé, "The Arabs in Spain."

Brooke.........."Church Missionary Intelligencer," C. M.

S., London, Eng. "Church Missionary

Gleaner," C. M. S., London, Eng.

Crowther........Page, Jesse, "The Black Bishop, Samuel Crowther, Samuel Adjai, "Journal of an Adjai Crowther," Fleming H. Revell, New York, 1907.

Expedition up the Niger and Tshadda Rivers," Church Missionary Society, London, Eng., 1855.

Page, Jesse, "Samuel Crowther, the Slave Boy who became Bishop of the Niger," Revell, New York, not dated.

Colllard........Favre, Edouard, "François Coillard," Société des Missions Evangéliques, Paris, 1908. 3 vols.

Mackintosh, C. W., "Coillard of the Zambesi," T. Fisher Unwin, London, 1907. I vol. 


\section{AFRICAN HEROES AND HEROINES}

Coillard, François, "Sur le Haut-Zambeze," Benger-Levrault et Cie., Paris, 1899. Schlunk, Martin, "François Coillard und die Mission am oberen Zambesi," Bertelsman, Gütersloh, 1904.

Grenfell........Hawker, George, "The Life of George Grenfell," Fleming H. Revell, New York, 1909.

Johnston, Sir Harry Hamilton, "George Grenfell and the Congo," Hutchinson \& Co., London, Eng., I908.

KraPF..........Krapf, Johann Ludwig, "Journals of the Rev. Messrs. Isenberg and Krapf, missionaries of the C. M. S.," Seely, Burnside \& Seely, London, Eng., 1843.

Krapf, J. L., "Travels, Researches and Missionary Labours," Trubner, London, Eng., I 860.

Claus, W., "Dr. Ludwig Krapf," Spittler, Basel, 1882.

Slessor.......... Livingstone, W. P., "Mary Slessor of Cal. abar," Hodder \& Stoughton, London, Eng., 1916.

Livingstone, W. P., "The White Queen of Okoyong," George H. Doran Company, New York.

MACKAY.........A. M. Mackay," by his sister, A. C. Armstrong \& Son, New York, I89o.

Harford, Charles F., "Pilkington of Uganda," Fleming H. Revell, New York, I899.

Fahs, Mrs. Sophie, "Uganda's White Man of Work, a Story of Alexander M. 
Mackay," Missionary Education Movement, New York, I9I2.

Wilson, C. T., "Alexander Mackay, Missionary Hero of Uganda," Sunday School Union, London, Eng., 1893.

Harrison, Mrs. J. W., "A. M. Mackay, Pioneer Missionary of the Church Missionary Society to Uganda," Armstrong, New York, 1895.

Tucker......... Tucker, Alfred Robert, "Eighteen Years in Uganda and East Africa," Edward Arnold, London, Eng., 1908.

Moffat.........Moffat, John S., "The Lives of Robert and Mary Moffat," A. C. Armstrong \& Son, New York, 1888.

Moffat, Robert, "Missionary Labours and Scenes in Southern Africa," Carter, New York, 1842.

Deane, D. J., "Robert Moffat the Missionary Hero of Kuruman," Revell, New York, 1888.

Moffat, Robert, "A Life's Labour in South Africa," Snow, London, Eng., I87I.

Wilder, M. L., "Memoir of Robert Moffat," Revell, Chicago, 1887.

Livingstone...... Blaikie W. Garden, "The Personal Life of David Livingstone," Fleming $\mathrm{H}$. Revell, New York, I88o.

Mathews, Basil, "Livingstone the Pathfinder," London Missionary Society, London, Eng., 1912.

Waller, Horace, "The Last Journals of 


\section{AFRICAN HEROES AND HEROINES}

David Livingstone," Harper \& Brothers, New York, 1875.

Stanley, Henry M., "How I Found Livingstone," Charles Scribner's Sons, New York, 1913.

Livingstone, David \& Charles, "Narrative of an Expedition to the Zambesi and its Tributaries, I858-1864," J. Murray, London, Eng., I 865.

Monk, Rev. William, "Dr. Livingstone's Cambridge Lectures," Deighton, Bell \& Co., Cambridge, Eng., I86o.

Livingstone, David, "Missionary Travels and Researches in South Africa," J. Murray, London, Eng., 1857.

Adams, H. G., "A Weaver Boy who Became a Missionary," Whittaker, New York, 1867.

Brice, A. J. Montefiore, "David Livingstone: his Labours and his Legacy," Revell, New York, I889.

Horne, Silvester, "David Livingstone," Missionary Education Movement, New York, I913. 


\section{INDEX}

Abdul Aziz, 151

Abdallah Ibn Saad, 20

Abeokuta, 52, 53, 54

Abyssinia, ro, 104, 105, ro9, 1ro, III, II2, II3, II4

Acbah Ihn Nafer, 21, 23

Adamawa, 35

Adjai (See Crowther)

EEneas, 4

Air (or Asben), 205

Akaba, Gulf of, ro

Akpap, 125

Alexander, 8, 18

Alexander, Boyd, 132

Alexandria, 8, 9, 11, 18, 19, 20, 30,

54, 104, 105, 110

Alexandrian Library, 19

Algeria, 9, 30, 32, 33, 54, 204

Amru, 17, 18, 19, 20

Antioch, 8

Apostle Street, 1 ro

Arabia, 10, 18, 20, 32, 33, 38

Arabs, 18, 24, 30, 31, 35, 92, 95

Arnot, 77

A rochuku, 125

Aros, 124

Arthington, Robert, 95, 96

Aryan, 12

Asano, 1 Io

Ashe, 148

Asia Minor, 31, 32

Asnières-les-Bourges, 60, 6r

Asser, 70
Assiut, 1 ro

Assuan, 1 ro

Athanasian Creed, 12

Athanasius, ro

Atlantic, 21

Atlas Mts., 10, 204

Augustine, St., 2, 10, 12

Azael, 70

Azhaar, 21

Babylon, 13

Badagry, 52

Baganda, 139, 152

Balolo, 93

Baluti, 99

Bangweolo, 172, 189

Bantus, 63, 140

Banyai, 7r

Barka, 3, 21, 26

Bari, 132

Barotseland, $60,63,74,75,77,80$,

$81,82,83$

Basle, 103, 104, 108

Basoko, 86, 93, 99

Barth, 177

Basutoland, 6o, 62, 63, 64, 67, 68,

$74,75,76,77,82$

Bechuana, I6o, I6I, I64, I8I

Bellefond, Linant de, I $_{3}$, I32 $_{3}$

Bengazi, 30

Eeni Shongul, r ro

Benin, Bight of, 125

Bennett, 188 
Benson (Archbishop), 146

Benue, 35, 37, 54

Berber, 21, 1 10

Bidimo (Grenfell), 93

Blantyre, 172, 192

Boehme, 104

Boer, 64, 67

Bola, 46

Bologna, 2

Bombay, I84

Bonar, Horatius, 134,136

British East Africa, 108

Brixton, 168

Brooke, Graham Wilmot (27 to 40), 138

Brooke, Lieut. Col., 28

Brooke, Mrs., 38

Brown, 177

Bruce, 103

Bukuru, 95

Bula Matari (Stanley), 33, 93

Bulawayo, 6o, 72

Byzantine, 19

Byzantium, 18, 20, 23

Cahina ( 15 to 26), 29

Cahina, Ihn, 2I

Cairo, 54, ro4, I 10

Cambridge, 28

Cameroons, 86, 89, 203

Candace, Queen, 9

Cape Town, 160, 167, 168

Carthage, 2, 3, 4, 5, 12, 21,22

Caucasian, 45, 46

Cetewayo, 161, 168

Chad, Lake, 30, 35, 54, II9, 204

Chitambo, 172, 192

Church Missionary Society, 28, $37,39,104,107,109,133,142$, 154
Churchill, Winston, 144

Clement, 9, ro

Cliff College, $8 \mathrm{I}$

Coillard, François (58 to 84 )

Colenso, Bishop, 67

Comber, Tom, 87

Condé, I 6, 22

Congo, 12, 31, 33, 35, 86, 89, 90, 93, 95,96

Constantine (City), 16, 22

Constantine (Emperor), ro

Constantinople, 20, 31

Cook, Drs., 153

Cooley, 114

Copts, is 8

Corona, II 9

Crane, Dr. Frank, 45

Creek Town, 125

Crowther, Samuel Adjai (4I to 57), 39

Cumming, Gordon, 177

Cyprian of Carthage, ro

Cyrenaica, 16, 26

Cyrene, 8, 21

Cyril of Alexandria, Io, 12

Damaris, 69

Darfur, 30, 35

Deken, van der, 114,132

Denham, 30

Derendingen, ro3

Devil's Cataract, I 80

Dhabba (Cahina), 16, 22

Diana, 5

Dido, 3

Donibristle, 160, 162, 163

Duala, 89

Duke Town, 125, 127

Durban, 67 
Durham Cathedral, 146

Dutch, 164

Edem, I24

Edgerly, 89

Edward, King, the Seventh, 83 , 88

Egba, 52

Egypt, 9, 16, 17, 18, 20, 23, 24, 25, 33, 132, 205

Erhardt, 114

Ekenge, 123, 125

Eko, 48

Eleazar, 70

Ephesus, 5

Esperanza Felix, 48

Ethiopia, 83

Etim, 124

Exeter Hall, 56

Eyo, 47

Fernando Po, 86

Fez, 21, 30

Fiske, 44

Flad, I I I

Fourah Bay, 5r

François, 95

Franciscans, 2, 21, 30

Gallaland, 109

Garenganze, 77

Gauls, 4

Gezira, ro

Gobat, ro9, I 15

Gondar, Iro

Goodwill, 96

Gordon, 28, 60, 76, 77, 132, 133, 186

Goths, 4

Grammarian, John, 19
Greeks, 18, 20, 21, 22

Gregorius, 16, 20, 22

Grenfell, George (86 to 99), 138

Guinness, 81, 89, I I 5

Guyon, 104

Hadrian, II

Hamitic, 94

Hamza, 38

Hanna, 54

Hann Alaca Wolda, III

Hannibal, 3

Hannington, Bishop, 28, 144, 149

Hasdrubal, 3

Hassan Ibn Annoman, 16, 22, 23, 24

Hawkes, 89

Hermon, 65

High Leigh, I6o, 163

Hilarianus, 2

Hill, Bishop, 40

Hillmore, 182

Hoffman, 66

Huguenots, $6 r$

Ibadan, 54

Ibi, 54

Iblis, 25

Ifumi, 67

Ikpe, 125

Ikotobong, 125

Inyati, 167

Irving, Washington, 16,22

Isa, 25

Itu, 125

Ituri, 93

Jeanmairet, 77,78

Jerusalem, ro9

Jesuits, 77 
Jews, 22

Johannisburg, 54

John (Greek Prefect), 22

John Mark, 8

Jolinston, Sir Harry, 90, 96, 114, I 86

Joubert, 77

Jukun, 54

Kabaka, 137

Kabyls, 12, 22

Kagei, 137

Kairouan, 2I

Kakumba, 148, 149

Kampala, I38, I48, 155

Karroo, I68, 204

Kassala, I13

Kempton, 99

Kenia, 108, I15, 203

Keswick Convention, II I

Khama, 73, 77, 147

Khartum, 54, 76, 110, 132

Kilimanjaro, I08, II4, II5, 203

Kingsley, Chas., 122

Kingsley, Mary, 122 to 125

Klein, I04

Koelle, ro4

Koran, 19, 31, 38

Kordofan, 35

Kufra Oases, 30

Krapf, J. L. ( 103 to I1 5 ), 177

Krapf, Mrs., 105, 106, 107, 108

Kuruman, I65, I66, I67, I68, 172

Lagos, 42, 52

La Fontaine, 67

Lavigerie, 3, 32

Leopold (King), 86, 90, 96

Leribe, 65
Letsuele, 65

Lewanika, 77, 78, 79, 80, 82, 83, 147

Lindsay, Vachel, 98

Livingstone, 30, 32, 73, 74, 103, I13, I 19, 122, 136, 138, 143, 154, 160, 161, 166 (172 to 192)

Lkonge, 137

Lobengula, 72, 73, 82, 147

Lokoja, 28, 37, 38

London Missionary Society, 163, I67, 174

Lomami, 92

Long, Edwin, 5

Lourdel, 147

Lualaba, 172, 183, 184, 189

Lubare, 147

Lucy Memorial Freed Slaves Home, 176

Lugalama, 148, 149

Luvusu, 99

Luxor, I Io

Lybia, 3, 19

Lybian Desert, 10, 19, 30, 204

Ma Akambo (See Slessor)

Mabotsa, 172, 174

Macdonald, 36

Mackay, Alexander M. (130 to 144), 138, 147, 154

Mahdi, 32

Mahomet, 106

Majasi, 149

Makololo, 63, 74, 182

Makulo, 99

Malta, I04

Mangwato, 77

Manjuema, I84

Ma Okoyong (See Slessor)

Maritzburg, 67 
Marseilles, 104

Mary (Virgin), 112

Masai, 94

Masonda, 71, 72

Massowa, 104, 105

Matabeleland, 70, 72, 161, 166

Mauritania, 3, 21, 26

Mauritius, 67,172

Maxwell, 40

Mebaline, 181

Mecca, 17, 19, 20

Mediterranean, $3 \mathbf{I}$

Meks, 19

Memphis, 17

Mengo, 137, 149, 152, 154

Murchison, Sir Roderick, r 30

Millman, 99

Miryam, 25

Misrah, 17

Moawyah, 21

Mobangi, 28, 29, 34, 92

Moffat, Robert (159 to 169 )

Mokawkas, 18

Molimo, 70

Mombassa, 105, 135, I50, 153

Moors, 22

Morocco, 9, 30, 33

Mosilikatse, I6I, 166

Moslems, 24, 49

Mountains of the Moon, I15

Mpwapwa, 137

Mtesa, 131, 147, I48, I 52

Mullah, 24

Musuko, 89

Mwanga, I43, 148, 149, 150, 154

Myrmidon, $5 \mathrm{I}$

Natal, 63, 67

Nehi, 47

New York, 45
Ngaka, 74

Niger, 12, 28, 30, 35, 37, 54, 119 , 205

Nigeria, 28

Nile, 20, I10, I15, 189, 204

Northern Nigeria, I19, 176

Norwood, 160

Nosseyr, Musa Ibn, 24, 38

Ntebbe, 137, 153

Nubia, 20, 115

Numidia, 3, 4, 2 I

Nyangwe, 183

Nyassa, Lady, 184

Nyassa, Lake, 136, 172, 182

Odoro Ikpe, 125

Okoyong, 121, 122, 123

Old Calabar, 127

Old Mammy Fuller, 127

Old Town, 125

Omar, 17

O'Neill, 137

Origen, 9

Ormiston, 160, 161

Oshogun, 42, 46, 47

Othman, 17

Palestine, 32

Park, Mungo, 35, 177

Paris, 60, 61, 62, 188

Paris, Mission, 63, 69, $8 \mathrm{I}$

Pantænus, 9

Paton, r6r

Pentecost, 8

Penzance, 86

Pères Blancs, 3

Perpetua ( 1 to 13 )

Persia, 32

Pfaender, 104

Philo, 8, 9 
Pilkington, 143

Pinto Serpa, 74, 75

Pioneer, 182

Plato, 8

Polyglotta Africana, ro4

Portugal, 76, 80, 90

Portuguese, 47, 75, II I

Pretoria, 77

Prester John, III, II3

Ptolemy, 8, II 5

Quilimane, 172

Quorra, 54

Quo Vadis, 5

Rappard, rog

Rebman, 105, 114, 177

Red Sea, 20

Reed, Henry, 95

Rhodes, Cecil, 8o

Rhodesia, 82

Riley, 189

Robinson, Rev. J. A., 28, 37, 39

Rome, 3, 5, 23

Rovula, 182

Royal Geographical Society, 90

Rubage, 137

Ruvenzori, 203

Said, ro5

St. Bartholomew, 61

St. Chrischona, I08, го9, I 10, I I 5

St. John (Hospital, Jerusalem), 126

Safari, 43

Sahara, 26, 34, 121, 204, 205

Saker, Alfred, 88

Sale, 3 I

Scipio, Africanus, 4

Scipio (the Younger), 4
Schoen, 104

Sechuana, 166, I 68

Sefula, 6o, 78, 84

Seleucid, 8

Senegambia, 28

Septuagint, 8

Seruwanga, 148, 149

Sesheke, 78

Severus, Septimius, 2

Shari, 12

Sheich ul Islam, 32

Shoa, II 2

Shodeke, 52

Shupanga, 172, 182

Sienkiewicz, 5

Sierra Leone, 5I, 52

Sinnussi, 32

Slessor, Mary (II 7 to $\mathrm{I} 28$ )

Smith (Congo), 99

Smith, Geo., 9

Smith, Lieut., 137

Smith, Miss, 160, 164

Speke, Capt., 135

Stanley Falls, 95

Stanley, H. M., 33, I13, 131, 133,

$$
\text { 136, 1 54, 188, 189 }
$$

Stanley Pool, 90

Stock, Eugene, 42

Strassburg, 60, 6I

Suahili, 105, I14, I39

Suakim, II 3

Sudan, 28, 29, 34, 35, 36, 37, 39, I32, I 54, I 67

Susannah, $5 \mathrm{I}$

Synesius, 12

Syria, 17

Tahuda, 2I

Takaungu, I05

Tanganyika, 114, 172, 187 
Taylor, Bayard, II4

Taylor, Hudson, $8 \mathrm{I}$

Tertullian, 2, ro

Thebais, ro

Theodorus, I 3

Timbuktu, 30

Tinney, 114, 132

Tipu Tip, 95

Townsend, Henry, 52

Trafalgar, 62

Trajan Canal, 20

Trannack Mill, 88

Transvaal, 75, 77, 188

Tripoli, 30, 31, 33, 34

Troglodytes, Io

Troy, 4

Tsade, 54

Tuareck, ro

Tuat (Oasis), 204

Tübingen, ro3, 104

Tucker, Bishop (146 to 158 )

Tunis, 9, 30, 33

Turks, 31, 32

Uchtritz, 95

Uganda, 28, 46, 130, 131, I33, $135,136,137,143,146,148,149$, I $50,152,153,154$

Ujiji, I72, 187

Ukerewe (Island), 137

Ulala, 172, 189, 192

Unyamwezi, II 5

Unyanyembe, 172

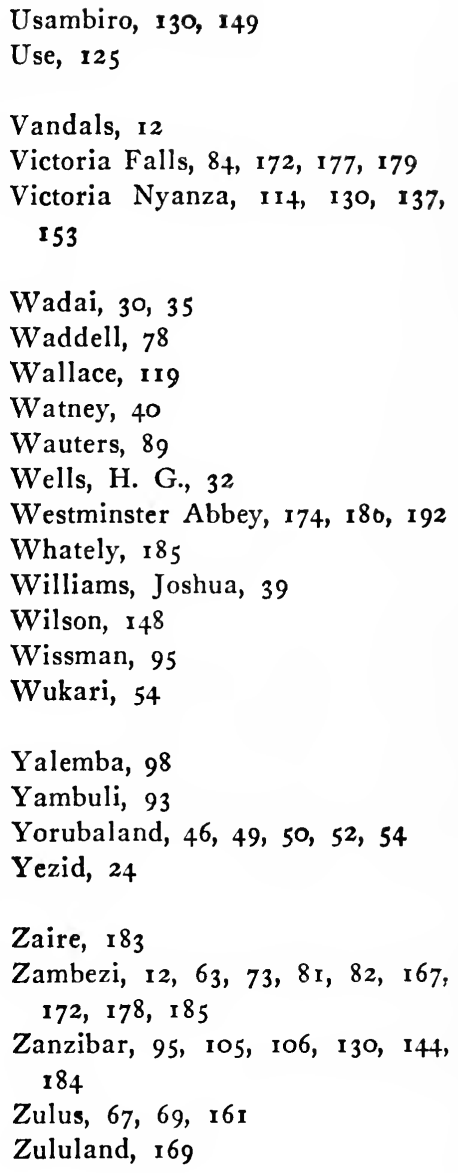

Printed in the U.S. A. 

The following pages contain advertisements of a few of the Macmillan books on kindred subjects. 



\section{David Livingstone}

By C. Silvester Horne

New edition, I2mo, illustrated, $\$ I .25$

"Mr. Horne has done a fine service in presenting the characteristic and strategic facts of the life and work of Livingstone and of his character and his service to humanity. . . . With fine discrimination, with skill in dramatic simplicity, Mr. Horne has made the great hero of Africa live and has brought into bold relief the moral qualities and lessons of his life."-Review and Expositor.

"We doubt if the story could be told more stirringly in krief compass than it is in Mr. Horne's book. By clever and free use of Livingstone's diaries and letters he is made to tell his own story in large part-and a wonderful story it was, of devotion, sacrifice, hardship, persistence, and adventure, through many dangers with beasts and men."-The Outlook.

"A very good biography. Gives in small compass a clear, simple narrative of Livingstone's adventurous and useful life." -New York Times.

"His vigorous style is well adapted to the portrayal of a life so full of activity and courageous undertaking as that of Livingstone."-The Independent.

"Here is given a graphic story of the patience and knowledge of human nature that enabled Livingstone, without any aid, to break up the infamous slave trade in many districts."-San Francisco Chronicle.

"Full of inspiration and information."-Philadelphia Press.

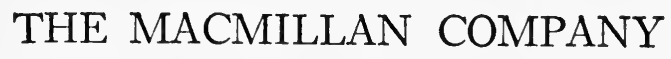

Publishers 64-66 Fifth Avenue New York 


\section{Concerning Immortality}

An essay in discovery, co-ordinating scientific, psychical and biblical research

Edited by Canon Streeter and written by A. Clutton Brock, B. H. Streeter, Dr. J. Hatfield, C. W. Emmett and E. W. Barnes.

Cloth, $8 v 0, \$ 2.50$

Among the main topics which this work takes up are the following: Certain Current Objections to a Belief in Immortality; The Grounds of Immortality; The Resurrection of the Body; Heaven; Re-Incarnation and Karma As Taught by Modern Theosophists; Communication with the Dead; Can Mind Survive the Destruction of the Brain; What Happens to the Sinner After Death, and The Communion of Saints. The volume, which has the same editorship as Concerning Prayer, is an important addition of permanent value to religious literature.

\section{THE MACMILLAN COMPANY}

Publishers 64-66 Fifth Avenue New York 


\section{The Work of Preaching}

By Arthur S. Hoyt, Professor of Homiletics and Sociology in Auburn Theological Seminary. New edition with new matter.

Cloth, I2mo, $\$ 1.50$

To his "interpretation of preaching as a living message" Dr. Hoyt now adds two new chapters and expands considerably his earlier treatment of "Illustration." His purpose is, as expressed in the preface, to help busy men in the ministry to measure their work and to renew their ideal of preaching and their faith in its power. Published originally nearly twelve years ago, it has, in that long period of time, well met the needs and as now enlarged there is every prospect that it will continue to be of very practical service. The chapters take up such topics as The Importance of Preaching, Preparation for Preaching, Preparation of the Sermon: The Introduction, The Development, The Conclusion; The Use of Explanation, Illustration, Persuasion; Preaching with Manuscript; Extemporaneous Preaching; The Oral Style and the Elements of Effective Preaching.

\section{THE MACMILLAN COMPANY Dublishers 64-66 Fifth Avenue New York}




\section{A Theology for the Social Gospel}

By Walter Rauschenbusch, Author of "Christianity and the Social Crisis" and "Christianizing the Social Order."

Cloth, I2mo, $\$ 1.50$

This book, which embodies the Taylor Lectures given at Yale during Convocation Week in April, I9I7, takes up the old doctrines of the Christian faith, such as Original Sin, The Atonement, Inspiration, The Sacraments, and shows how they can be re-interpreted from a modern social point of view and expanded in their scope so that they will make room for the salvation of society as well as for the salvation of individuals. The work is practical and inspiring and covers ground not previously traversed by writers.

\section{THE MACMILLAN COMPANY} Publishers 64-66 Fifth Avenue New York 


\section{The Hartford-Lamson Lectures on the Religions of the World}

\section{An Introduction to the Study of Comparative Religion}

By Frank Bryon Jevons.

Cloth, I2mo, $\$ 1.50$

"It is an admirable introduction to the subject, clear in style, sound in method, and with a comprehensive grasp of facts."New York Times.

\section{The Religion of the Chinese}

By Dr. J. J. M. DE Groot.

Cloth, I2mo, $\$ 1.25$

"A scholarly and detailed account of the intricate religions of the Chinese-which up to late years have been impenetrable puzzles to the Occidental mind."

\section{Aspects of Islam}

By Duncan Black Macdonald, M.A., D.D.

Cloth, I2mo, $\$ 1.50$

"The work will prove of exceptional value to any one who may come in contact with the various forms of Muslimism."

\section{The Faith of Japan}

By TASuku Harada

Cloth, I2mo, $\$ 1.25$

There are excellent works on the religions of Japan, but President Harada is the first authority to write on its faith. He expounds not religious systems, but those instinctive principles by which the Japanese live.

\section{Modern Religious Movements in India}

By J. W. Farquhar Cloth, 8vo, illustrated, $\$ 2.50$

This comprehensive survey of present-day religious tendencies in India is of tremendous importance and significance to every student of religion.

\section{THE MACMILLAN COMPANY}

Publishers 64-66 Fifth Avenue New York 


44158954 


\section{caven LISRaRY \\ KHOX COLLEGE \\ TORONTO}

\section{KNOX COLLEGE LIBRARY}




\section{(3)

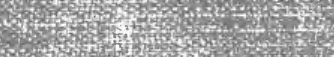 \\ (1) \\ (1)}

1.

x

a

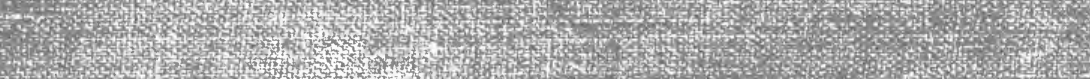

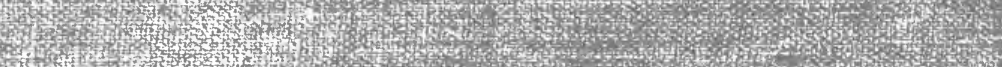

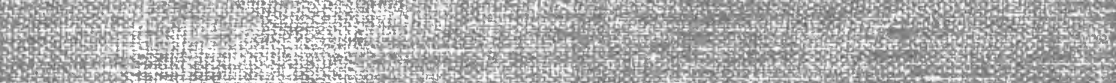

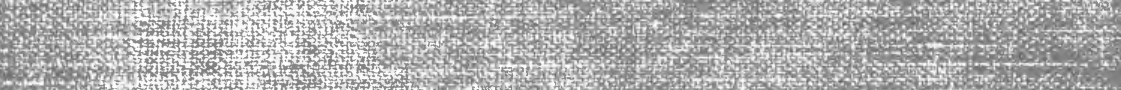

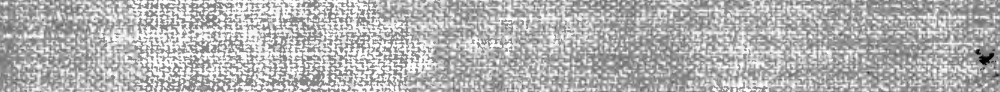

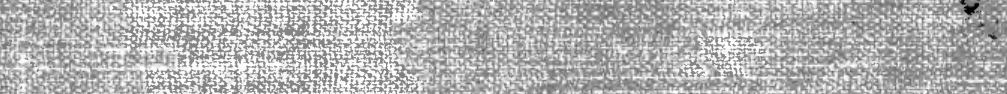

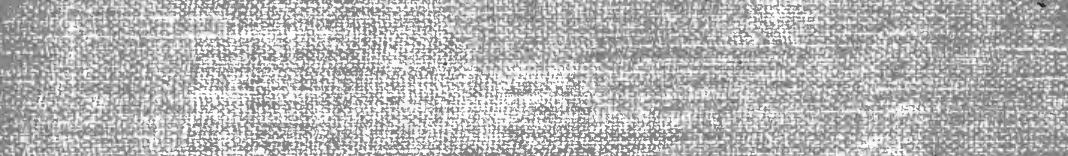

Hoth

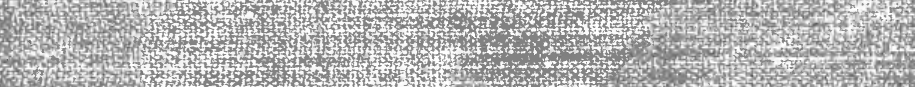

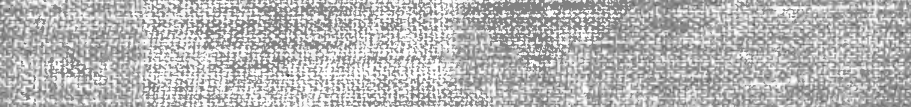

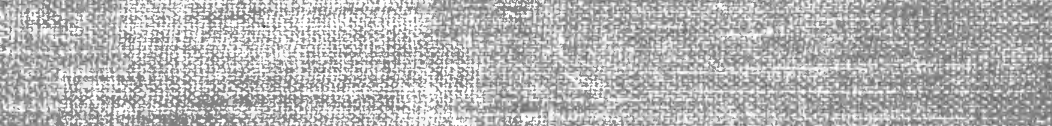

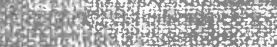

W

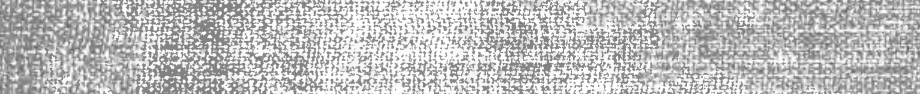

187.

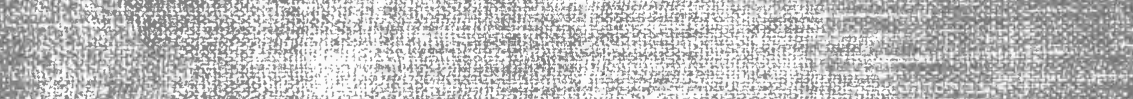

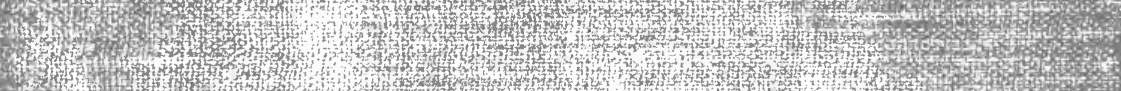

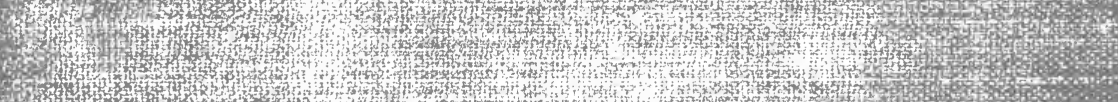

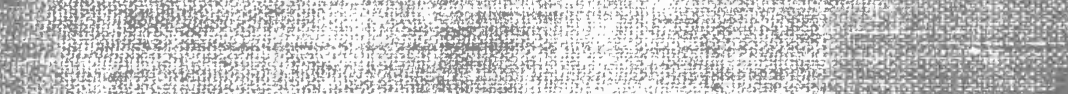

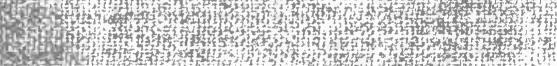
4

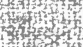

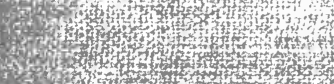

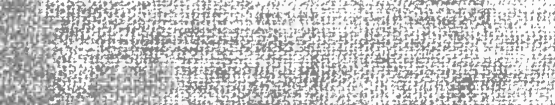

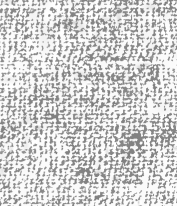

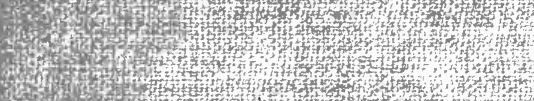

H.TH

H.74

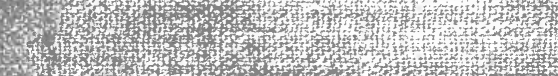
H. 